\title{
CARACTERIZAÇÃO HIDROLÓGICA DE DUAS MICROBACIAS VISANDO A IDENTIFICAÇÃO DE INDICADORES HIDROLÓGICOS PARA O MONITORAMENTO AMBIENTAL DO MANEJO DE FLORESTAS PLANTADAS
}

\section{ANDREIA ARRUDA DE OLIVEIRA MOSCA}

\begin{abstract}
Dissertação apresentada à Escola Superior de Agricultura "Luiz de Queiroz", Universidade de São Paulo, para obtenção do título de Mestre em Recursos Florestais, Área de Concentração: Conservação de Ecossistemas Florestais.
\end{abstract}

PIRACICABA

Estado de São Paulo - Brasil

Junho - 2003 


\title{
CARACTERIZAÇÃO HIDROLÓGICA DE DUAS MICROBACIAS VISANDO A IDENTIFICAÇÃO DE INDICADORES HIDROLÓGICOS PARA O MONITORAMENTO AMBIENTAL DO MANEJO DE FLORESTAS PLANTADAS
}

\section{ANDREIA ARRUDA DE OLIVEIRA MOSCA}

Geógrafo

Orientador: Prof. Dr. WALTER DE PAULA LIMA

\begin{abstract}
Dissertação apresentada à Escola Superior de Agricultura "Luiz de Queiroz", Universidade de São Paulo, para obtenção do título de Mestre em Recursos Florestais, Área de Concentração: Conservação de Ecossistemas Florestais.
\end{abstract}

PIRACICABA

Estado de São Paulo - Brasil

Junho - 2003 
Dados Internacionais de Catalogação na Publicação (CIP)
DIVISÃO DE BIBLIOTECA E DOCUMENTAÇÃO - ESALQ/USP

Mosca, Andreia Amuda de Oliveira

Caracterização hidrológica de duas mic robacias visando a identific ação de indicadores hidrológic os para o monitoramento ambiental do manejo de florestas plantadas/ Andreia Amuda de Oliveira Mosca. - - Piracic aba, 2003.

88 p. : il.

Dissertação (mestrado) - - Escola Superior de Agricultura Luiz de Queiroz, 2003.

Bibliografia.

1. Balanço hídrico 2. Compactação dossolos 3. Hidrologia florestal 4. Manejo florestal 5. Mic robacia hidrográfic a 6. Monitoramento ambiental' Proteção am- biental 8. Qualidade da água I. Título

CDD 634.9

"Permitida a cópia total ou parcial deste documento, desde que citada a fonte - O autor" 
Aos meus pais, João Afrânio e Maria Henriqueta, e minhas irmãs: pelo amor, exemplo de luta e apoio constante.

Nas quedas é que o rio cria energia

(Hermógenes)

Ao meu querido esposo, Guilherme, pelo amor, companheirismo e compreensão. 


\section{AGRADECIMENTOS}

Agradeço a Deus por todos os momentos.

Agradeço a todos que também ajudaram, diretamente ou não, na construção e materialização deste trabalho e peço desculpas àqueles que, porventura, não sejam citados mas saibam que levo comigo uma eterna gratidão.

Ao Professor Dr. Walter de Paula Lima, por sua valiosa orientação, apoio, confiança e pelo tempo, pacientemente dedicado, a tantas dúvidas surgidas no caminho. Por acreditar no projeto Catalão, hoje concretizado.

À empresa Eucatex pelo apoio e empenho no desenvolvimento da pesquisa e coleta de dados e a todo o pessoal da Fazenda Santa Terezinha, Bofete e São Roque Novo, pela amizade e carinho.

Ao Marquinhos, pela agilidade e competência empenhadas no programa de monitoramento das microbacias hidrográficas, no acompanhamento das amostragens efetuadas em campo e especial amizade.

Ao Departamento de Ciências Florestais da ESALQ/USP, por possibilitar a realização do curso de pós-graduação.

Ao CNPq pela bolsa de estudos concedida.

À ESALQ/USP, pela moradia na Vila Estudantil da Pós-Graduação.

Ao Laboratório de Hidrologia Florestal da ESALQ/USP pela disponibilização dos dados e contribuição na orientação e viabilização do trabalho. 
À Zezé, por tornar a vida mais alegre, pela dedicação e amizade.

Aos mestres do Curso de Geografia do Campus da Universidade Federal de Goiás, em Catalão, por prepararem as bases do caminho a ser percorrido.

Aos companheiros de pós-graduação pelas contribuições na discussão da pesquisa, amizade, apoio e solidariedade nos momentos difíceis.

Ao pessoal da Vila Estudantil pelos bons momentos compartilhados.

Ao Marcelino, pela ajuda na análise estatística dos dados, amizade e por nos representar de forma tão íntegra e zelosa junto à Comissão de Pesquisa e PósGraduação da ESALQ/USP.

À Lira e ao Pedro Miguel pela amizade eterna e inestimáveis contribuições em todos os aspectos.

À Carlinha Câmara pela ajuda na análise dos hidrogramas, amizade e disposição.

Ao Alê (xandre), àAninha e àOca pela amizade e prontidão. 


\section{SUMÁRIO}

Página

LISTA DE FIGURAS............................................................................ ix

LISTA DE TABELAS ............................................................................. x

LISTA DE QUADROS................................................................................ x xiv

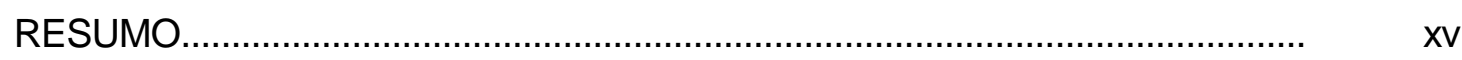

SUMMARY

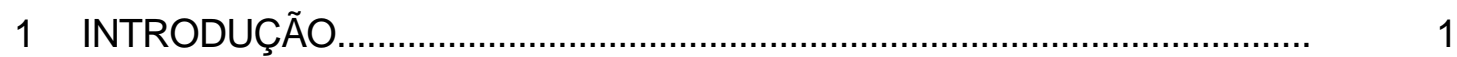

2 REVISÃO DE LITERATURA............................................................. 3

2.1 Efeitos das florestas sobre as águas...................................................... 3

2.2 A bacia hidrográfica como unidade de estudo............................................. 5

2.3 Caracterização hidrológica de microbacias e a identificação de indicadores...................................................................................... 8

2.4 O balanço hídrico e avaliação do consumo de água pela floresta.................. 13

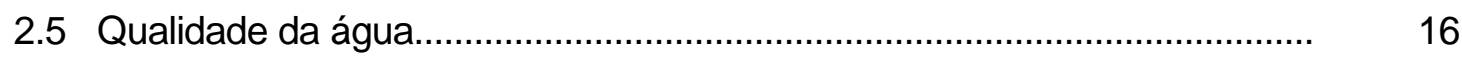

2.5.1 Parâmetros Físicos............................................................................ 19

2.5.2 Parâmetros químicos............................................................................ 20

2.6 A compactação do solo e seus efeitos hidrológicos na microbacia............... 21

3 MATERIAL E MÉTODOS......................................................................... 24

3.1 Área de estudo.............................................................................. 24

3.2 Localização da área experimental......................................................... 26 


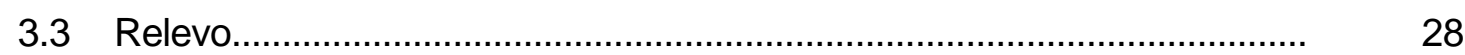

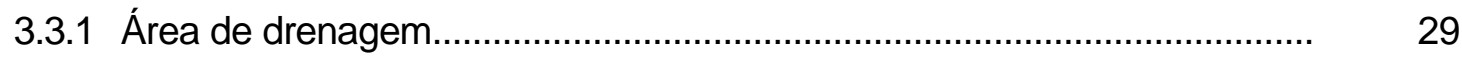

3.3.2 Forma

3.3.3 Coeficiente de compacidade $(\mathrm{Kc})$.......................................................... 29

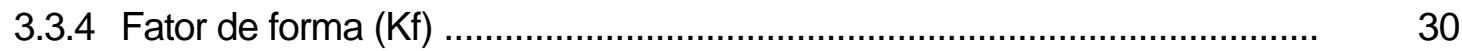

3.3.5 Razão de elongação $(\mathrm{Re})$................................................................. 30

3.3.6 Índice de circularidade (IC) …………………………………………........ 31

3.3.7 Ordem dos rios ................................................................................. 31

3.3.8 Densidade de drenagem (Dd) …………………………………........ 31

3.4 Clima

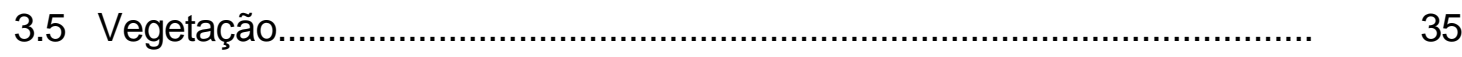

3.6 Geologia..................................................................................... 38

3.7 Solos e geomorfologia............................................................................ 38

3.8 Fluviometria e pluviometria............................................................................ 41

3.8.1 Medição do deflúvio..................................................................................... 42

3.8.2 Medição da precipitação......................................................................... 45

3.8.3 Balanço hídrico ......................................................................................... 45

3.9 Comparação das características do deflúvio das microbacias...................... 46

3.10 Qualidade da água: monitoramento dos parâmetros físico-químicos........ 46

3.11 Compactação do solo.............................................................................. 47

3.11.1 Densidade de partículas $(\rho p)$.............................................................. 48

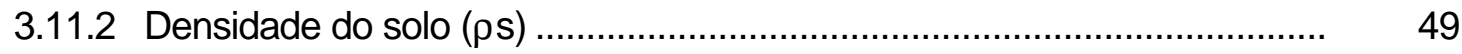

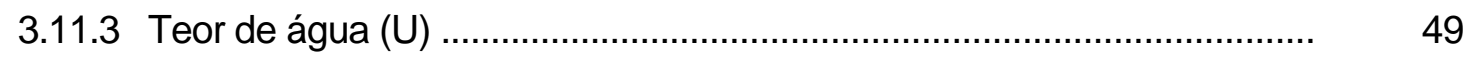

3.11.4 Índice de cone (IC) ...................................................................... 49

5 RESULTADOS E DISCUSSÃO..................................................................... 50 
5.1 Balanço hídrico......................................................................... 50

5.2 Características hidrológicas...................................................................... 55

5.3 Qualidade da água.......................................................................... 62

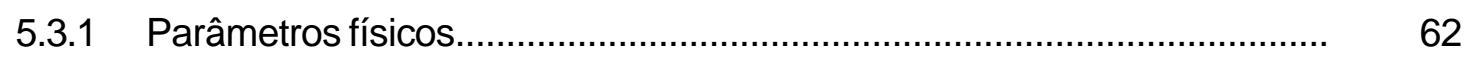

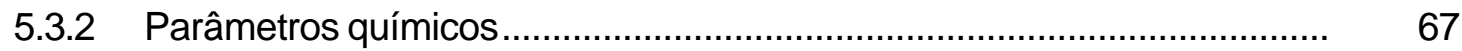

5.4 Densidade de partículas $(\rho p)$, densidade do solo ( $\rho s)$ e teor de umidade

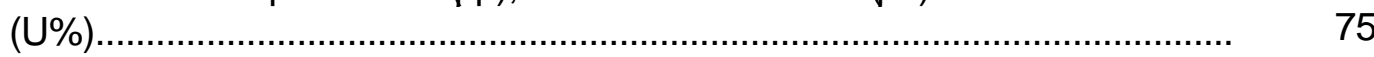

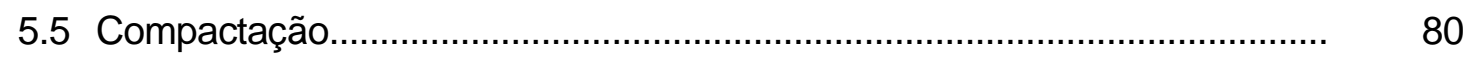

5.6 Indicadores qualitativos ou visuais da saúde das microbacias...................... 84

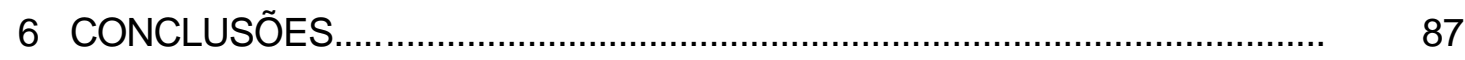

REFERÊNCIAS BIBLIOGRÁFICAS ........................................................... 89

APÊNDICES............................................................................................ 97 


\section{LISTA DE FIGURAS}

Página

1 Contexto espacial de inserção das microbacias na paisagem (escala macro)

2 Localização da área de estudo e identificação das microbacias.................... 26

3 Distribuição dos talhões na microbacia E.................................................... 28

$4 \quad$ Variação altimétrica na microbacia E........................................................... 33

5 Variação altimétrica determinada pelo Modelo Digital do Terreno para a microbacia $P$

6 Variação da Temperatura e Umidade Relativa do Ar no período de 35 setembro/01 a agosto/02.

$7 \quad$ Eucalipto (esquerda) e mata ciliar (direita), na microbacia E....................... 37

$8 \quad$ Cobertura vegetal da microbacia P.......................................................... 37

$9 \quad$ Aspecto da mata ciliar presente na microbacia P...................................... 38

10 Visão lateral do vertedor instalado na microbacia P..................................... 43

11 Visão àmontante do vertedor instalado na microbacia E.............................. 43

12 Estação meteorológica instalada na área experimental da Fazenda Santa Terezinha.

13 Amostragem realizada na linha de plantio para avaliar o Efeito "A" da compactação do solo na microbacia $\mathrm{E}$.

14 A primeira fotografia, da esquerda para a direita, refere-se a coleta dos dados de índice de cone na trilha de pisoteio do gado, na microbacia P. A segunda, mostra a coleta das amostras indeformadas de solo para determinação da densidade e teor de umidade. 
15 Representação esquemática do balanço de massa efetuado para a microbacia $E$, sendo: $P$ (entrada de água no sistema via precipitação); ET (saída via evapotranspiração) e Q (deflúvio)

16 Representação esquemática do balanço de massa efetuado para a microbacia $P$, sendo: $P$ (entrada de água no sistema via precipitação); ET (saída via evapotranspiração) e Q (deflúvio)

17 Verificação da homogeneidade dos dados de precipitação coletados na estação meteorológica instalada na área do experimento...

18 Hidrograma gerado para a microbacia $E$ em função da chuva ocorrida em $29 / 11 / 01$

19 Hidrograma gerado para a microbacia P em função da chuva ocorrida em 29/11/01.....

20 Hidrograma gerado para a microbacia E em função da chuva ocorrida em 07/04/02.

21 Hidrograma gerado para a microbacia $P$ em função da chuva ocorrida em 07/04/02.

22 Hidrograma gerado para a microbacia $\mathrm{E}$ em função da chuva ocorrida em 20/09/02.

23 Hidrograma gerado para a microbacia $\mathrm{P}$ em função da chuva ocorrida em 20/09/02.

24 Precipitação e turbidez média mensal no deflúvio das microbacias.

25 Valores médios mensais da cor real no deflúvio das microbacias.

26 Valores médios mensais de condutividade no deflúvio das microbacias........

27 Valores médios mensais de sedimentos na água das microbacias......

28 Valores médios mensais do $\mathrm{pH}$ na água do deflúvio das microbacias.....

29 Valores médios mensais do nitrato (nitrogênio) no deflúvio das microbacias 70

30 Valores mensais de fósforo na água das microbacias.

31 Valores mensais de potássio na água das microbacias

32 Valores mensais de cálcio na água das microbacias...

73

33 Valores mensais de magnésio na água das microbacias 
34 Densidade do solo na microbacia E.................................................................. 76

35 Densidade do solo verificada na microbacia P .....................................................

36 Densidade do solo na microbacia P: valores observados na trilha e fora da trilha de pisoteio do gado, na profundidade de 5 a $10 \mathrm{~cm}$

37 Compactação do solo observada na microbacia E para a linha de plantio e entre linhas.

38 Compactação do solo observada na microbacia $\mathrm{P}$ para a trilha de pisoteio do gado e fora da trilha.

39 Índices de cone para a microbacia $\mathrm{E}$ : valores encontrados na linha de plantio e entre linhas

40 Índices de cone para a microbacia P: valores observados na trilha e fora da trilha de pisoteio do gado.

41 Indicadores visuais propostos para integrar a avaliação do estado da saúde das microbacias monitoradas... 


\section{LISTA DE TABELAS}

Página

1 Macro escala e indicadores da proteção do solo e da água para o manejo sustentável das plantações florestais.

2 Meso escala e indicadores da proteção do solo e da água para o manejo sustentável das plantações florestais.

3 Micro escala e indicadores da proteção do solo e da água para o manejo sustentável das plantações florestais

4 Características Físicas do solo das microbacias

5 Parâmetros químicos do solo das microbacias

6 Balanço de massa para a verificação das perdas médias por evapotranspiração nas microbacias monitoradas no período de nov/00 a out/02.

7 Discriminação dos componentes dos hidrogramas analisados para 0 período experimental.

8 Caracterização das precipitações referentes aos hidrogramas analisados...

9 Perdas médias mensais de nutrientes no deflúvio da microbacia $\mathrm{E}$.

10 Perdas médias mensais de nutrientes no deflúvio da microbacia $\mathrm{P}$

11 ANOVA para a densidade do solo na microbacia E: linha de plantio e entre linhas.

12 ANOVA: densidade do solo para a microbacia P: trilha e fora da trilha de pisoteio do gado.

13 Média e desvio padrão da densidade e umidade do solo na camada de 5 a $10 \mathrm{~cm}$ de profundidade.

14 ANOVA para os valores de densidade do solo da microbacia $\mathrm{P}$ avaliados na trilha e fora da trilha, na profundidade de 5 a $10 \mathrm{~cm}$ 
15 Média e desvio padrão da densidade e umidade do solo na camada de 12,5 a $17,5 \mathrm{~cm}$.

16 ANOVA para microbacia $\mathrm{E}$ : dados transformados para atingir homocedasticidade $(Y=\log X)$ e avaliar o efeito da compactação do solo na linha de plantio e entre linhas.

17 ANOVA para avaliar o efeito da compactação do solo na microbacia P: na trilha do gado e fora da trilha de pisoteio do gado. 


\section{LISTA DE QUADROS}

Página

1 Características dos talhões que compõem a vegetação da microbacia E.....

2 Características morfométricas das microbacias da Fazenda Santa Terezinha.

3 Métodos utilizados na determinação dos parâmetros químicos do solo......

4 Coeficiente de correção dos valores de vazão das microbacias em situações de escoamento com afogamento.

5 Balanço Hídrico para $100 \mathrm{~mm}$ de capacidade de armazenamento de água para Conchas, Anhembi e Itatinga (SP), no período de 1941 a 1970.

6 Localização das estações meteorológicas utilizadas para verificar a consistência dos dados das microbacias estudadas.

7 Valores médios e variação (mínimo e máximo) da turbidez, cor real, condutividade, sedimentos e $\mathrm{pH}$ no deflúvio das microbacias $\mathrm{E}$ e $\mathrm{P}$

8 Valores médios e variação (mínimo e máximo) do nitrato, fósforo, potássio, cálcio e magnésio no deflúvio das microbacias $\mathrm{E}$ e $\mathrm{P}$. 


\title{
CARACTERIZAÇÃO HIDROLÓGICA DE DUAS MICROBACIAS VISANDO A IDENTIFICAÇÃO DE INDICADORES HIDROLÓGICOS PARA O MONITORAMENTO AMBIENTAL DO MANEJO DE FLORESTAS PLANTADAS
}

\author{
Autora: ANDREIA ARRUDA DE OLIVEIRA MOSCA \\ Orientador: Prof. Dr. WALTER DE PAULA LIMA
}

\section{RESUMO}

O presente trabalho consistiu na caracterização hidrológica de duas microbacias visando identificar critérios e indicadores hidrológicos que possam contribuir para a implementação de melhores práticas de manejo nas plantações de eucalipto e para o esclarecimento de possíveis impactos dessa atividade sobre a produção de água em quantidade e qualidade, na escala da microbacia hidrográfica. As microbacias experimentais monitoradas localizam-se na Fazenda Santa Terezinha, município de Bofete (SP). A microbacia E possui Eucalyptus grandis, usado para fins de serraria pela Eucatex S.A. Situada na mesma vertente da Bacia do Rio do Peixe, a microbacia $\mathrm{P}$ é destinada à pecuária extensiva, uso tradicional da terra na região. $\mathrm{A}$ caracterização hidrológica quantitativa baseou-se na análise dos dados pluviométricos e fluviométricos obtidos no decorrer de 2 anos de monitoramento contínuo (novembro de 2000 a outubro de 2002). A precipitação média anual registrada no ano hídrico de nov/00 a out/01 foi de $1.893,80 \mathrm{~mm}$ e 1.407,90 para nov/01 a out/02. O deflúvio anual 
para a microbacia $E$ no primeiro ano hídrico foi de $148,76 \mathrm{~mm}$ e de $125,62 \mathrm{~mm}$, para o segundo. As perdas médias ocasionadas por evapotranspiração no período monitorado somaram 1.513,66 mm. Para a microbacia $P$, o deflúvio observado para o ano hídrico de nov/00 a out/01 correspondeu a 383,35 mm e para nov/01 a out/02, 365,67 mm. As perdas médias por evapotranspiração nessa microbacia corresponderam a 1276,34 mm. A temperatura média observa entre set/01 a ago/02 foi de $21,38 \stackrel{\circ}{ } \mathrm{C}$ e a umidade relativa média, de $69,67 \%$. A microbacia $\mathrm{P}$ apresentou uma maior variação para todos os parâmetros físico-químicos usados para avaliar a qualidade da água do deflúvio e uma resiliência menor. As reduzidas concentrações de nutrientes no deflúvio da microbacia $\mathrm{E}$ e seu padrão estável de comportamento indicam melhor estabilidade hidrológica equilíbrio da floresta. $\mathrm{Na}$ microbacia $\mathrm{E}$ verificou-se que a resistência do solo à penetração para a linha de plantio, entre árvores foi inferior àquela observada fora da linha de plantio. Para a microbacia $\mathrm{P}, \mathrm{a}$ avaliação foi feita na trilha de pisoteio do gado e fora da trilha, sendo que na trilha os valores de densidade do solo e índice de compactação foram mais expressivos. Os indicadores visuais sugeridos mostraram correspondência com os demais resultados observados. As microbacias hidrográficas monitoradas fazem parte do programa mais abrangente de Monitoramento e Modelagem de Bacias Hidrográficas desenvolvido pelo Instituto de Pesquisa e Estudos Florestais, através do Laboratório de Hidrologia Florestal do Departamento de Ciências Florestais da Escola Superior de Agricultura "Luiz de Queiroz", Universidade de São Paulo (ESALQ/USP). 


\title{
HYDROLOGICAL CHARACTERISTICS OF EXPERIMENTAL CATCHMENTS FOR THE IDENTIFICATION OF HYDROLOGICAL INDICATORS FOR THE ENVIRONMENTAL MONITORING OF FOREST PLANTATIONS
}

\author{
Author: ANDREIA ARRUDA DE OLIVEIRA MOSCA \\ Adviser: Prof. Dr. WALTER DE PAULA LIMA
}

\section{SUMMARY}

The present work consisted of the hydrological characterization of two catchments aiming to identify hydrologic criteria and indicators that can contribute for the implementation of better management practices of Eucalyptus plantations, as well as the evaluation of possible impacts of these activities on catchment yield and quality. The experimental catchments are located at Fazenda Santa Terezinha, Bofete (SP). The catchment $\mathrm{E}$ is covered with Eucalyptus grandis, management for sawmill situated at Eucatex S.A. Catchment $P$ is covered with pasture, traditional land use in the region. The quantitative hydrological characterization was based on the analysis of rainfall and streamflow data during two consecutive years (November of 2000 the October of 2002). The average annual precipitation for the water year of nov/00 out/01 was $1.893,80 \mathrm{~mm}$ and $1,407.90 \mathrm{~mm}$ for nov/01 out/02. The annual streamflow for the same water years were $148,76 \mathrm{~mm}$ and $125,62 \mathrm{~mm}$, respectively. The average losses caused by evapotranspiration in the monitored period amounted to $1,513.66 \mathrm{~mm}$. For catchment $P$, the streamflow observed for the water year of nov/00 out/01 corresponded to 383,35 
$\mathrm{mm}$ and for nov/01 out/02, to $365,67 \mathrm{~mm}$. The average losses for evapotranspiration in this catchment corresponded to $1276,34 \mathrm{~mm}$. The average temperature observed between set/01 ago/02 was $21,38 \stackrel{\circ}{C}$ and the average relative humidity, $69,67 \%$. Catchment $P$ presented a higher variation for all the studied parameters used physicistchemistries to evaluate the quality of the water of the emanation and a lesser resilience. The reduced concentrations of nutrients losses in streamflow of catchment E, coupled with a more stable hydrological responses, reflect better protection from Eucalyptus forest. In the catchment, it was verified that the soil resistance to penetration in the plantation line, between trees, was lower than that observed outside of the plantation line. For catchment $P$, the evaluation it was made in the cattle track, where the values of soil bulk density and resistance to penetration were higher than those observed outside the cattle track. The suggest visual indicators of catchment health shown correspondence with the observed results. The monitored catchments are part of a broader of catchment environmental and monitoring developed by the Institute of Forest Research and Studies, through the Laboratory of Forest Hydrology of the Department of Forest Sciences of the Escola Superior de Agricultura "Luiz de Queiroz", University of São Paulo (ESALQ/USP). 


\section{INTRODUÇÃO}

Plantações florestais são freqüentemente questionadas a respeito de possíveis impactos ambientais negativos, principalmente aqueles relacionados com o consumo de água e perdas de solo e de nutrientes. Estes questionamentos são, na maioria das vezes, carentes de fundamentação científica e freqüentemente abordados como verdade absoluta. Alguns exemplos podem ser observados em artigos publicados recentemente. Um dos artigos ${ }^{1}$ afirma que "O eucalipto suga água do fundo do solo em excesso". Outro ${ }^{2}$ relata "... há cerca de 26 anos o Jequitinhonha era um vale fértil, de múltiplas culturas e criações, e começou a 'secar' graças à substituição das matas nativas pela plantação indiscriminada do eucalipto". No Estado do Espírito Santo a polêmica tornou-se ainda maior por ocasião da aprovação, em 2001, de uma lei estadual $^{3}$ proibindo novas plantações da árvore até que fosse realizado o mapeamento agroecológico do Estado. Nesse mesmo ano o Supremo Tribunal Federal definiu pela inconstitucionalidade da lei, mas a polêmica acerca do tema ainda continua.

Em função destas possibilidades, que realmente podem acontecer associado ao manejo inadequado, torna-se necessário o contínuo monitoramento das ações de manejo, tanto para a quantificação destes possíveis impactos, quanto para nortear a busca do manejo sustentável.

Estudos conduzidos desde o final do século XIX em microbacias experimentais instaladas em vários lugares do mundo têm, contudo, se mostrado cientificamente

\footnotetext{
${ }^{1}$ PESSOA, C., 2001. A reserva de um milhão de eucaliptos. Revista Terra, www.revistaterra.com.br (27 fev. 2001.) CHAVES, M. Eucalipto fará o Jequitinhonha de SP? http://www.estado.estadao.com.br/editorias/03/03/08/aberto002.html (13 de mai. 2003).

${ }^{3}$ Lei 6.780/2001, aprovada pela Assembléia Legislativa do Espírito Santo. http://www.ibase.org.br/paginas/deserto.html (09 de jan. 2003).
} 
eficientes na avaliação da produção e qualidade da água dos riachos, diversidade biológica e ciclagem de nutrientes comparando microbacias recobertas por espécies florestais de rápido crescimento à vegetação natural e atividades agropecuárias. Os resultados são surpreendentes e esclarecedores.

Alguns elementos-chave para a discussão estão alicerçados nos conceitos de manejo sustentável, saúde da microbacia, integridade e resiliência do ecossistema, dentre outros que são discutidos no decorrer do trabalho.

Pela complexidade da problemática, não se pretende reduzir o ciclo da água, "...a um fenômeno que se desenvolve fora da sociedade como se fôra um ciclo de evaporação-condensação-precipitação-infiltração-nascente/exposição à evaporação e ....". Procura-se, ao contrário, agregar subsídios para o debate do modelo agrícolaagrário ora estabelecido em busca de orientação para a implementação de melhores práticas de manejo das florestas plantadas.

As hipóteses testadas foram as seguintes: a produção de água na microbacia com floresta é mais regularizada ao longo do ano, em função da maior possibilidade de infiltração da água no solo; a compactação do solo é mais elevada na entrelinha de plantio, em função das operações florestais; uma maior variação mensal de nutrientes na água do deflúvio indica uma maior degradação ambiental do ecossistema.

O objetivo geral do presente trabalho foi caracterizar alguns aspectos quantitativos e qualitativos do balanço hídrico, da compactação do solo e da qualidade da água do deflúvio das microbacias.

Especificamente, buscou-se avaliar a influência da cobertura vegetal sobre o regime hidrológico, através do balanço hídrico regional e local; verificar o nível de compactação do solo para as microbacias e caracterizar a qualidade da água do deflúvio com base nos parâmetros físico-químicos: cor, turbidez, condutividade, sedimentos em suspensão, N, P, K, Ca e Mg.

${ }^{4}$ Gonçalves, C.W.P. Água: de técnicos, de outros protagonistas e de outras histórias. Geografia: Textoaberto. AGB-Nacional (Associação dos Geógrafos Brasileiros). Disponível em http://www.cibergeo.org/agbnacional/documentos/textoaberto10.html (24 de jun. 2002). 


\section{REVISÃO DE LITERATURA}

\subsection{Efeitos das florestas sobre as águas}

A compreensão do efeito que as florestas exercem sobre as águas é fundamental para auxiliar no esclarecimento de questões como: "Diante das críticas negativas à eucaliptocultura, feitas por ambientalistas, o cultivo de eucalipto pode afetar seriamente as reservas subterrâneas de água, causando a desertificação?"5.

"A importância das florestas no balanço hídrico não está ligada ao aumento da água no solo, ou da precipitação, mas ao efeito regulador que as florestas exercem sobre esse balanço" (Schumacher \& Hoppe, 1998).

"Com base nos resultados obtidos em mais de 90 microbacias experimentais em várias partes do mundo, pode-se, hoje, afirmar que o desmatamento diminui a transpiração, a interceptação e, consequentemente, a evapotranspiração, o que resulta em uma quantidade maior de água disponível no solo que, por sua vez, pode aumentar o deflúvio da microbacia, ou recarregar o lençol freático, enquanto o seu reflorestamento diminui a produção de água" (ReMAM, 2002).

Efeitos semelhantes também foram citados por Reinhart \& Pierce (1964) e Corbett \& Lynch (1985).

"Do ponto de vista do estabelecimento de plantações florestais com o propósito de melhorar as condições hidrológicas de bacias degradadas, 0

\footnotetext{
5 CRUZ, G. D. da. Reportagem sobre eucaliptos. Centro de documentação - ETM. Revista Ecologia e Desenvolvimento, Rio de Janeiro (e-mail recebido em 16/01/2001).
} 
uso do eucalipto parece promover, com o devido tempo, um adequado controle dos processos de escoamento superficial, erosão e ciclagem de nutrientes, contribuindo dessa forma para a melhoria da qualidade da água produzida pela bacia" (Lima, 1996).

Segundo Cossalter \& Pye-Smith (2003) quando a plantação é estabelecida, haverá, inevitavelmente uma mudança no ciclo hidrológico. A natureza da mudança dependerá de qual tipo de habitat as plantações substituem. Quando a floresta natural é convertida em uma plantação, as maiores mudanças ocorrerão durante os primeiros poucos anos seguintes da derrubada e plantio. Em contraste, quando as plantações são desenvolvidas em pastagens, a mudança inicial na hidrologia será ligeira, mas tornará progressivamente mais pronunciada na medida em que a plantação aproxima da maturidade.

Em relação ao elevado consumo de nutrientes e água do solo e a outros possíveis efeitos ambientais do eucalipto, Lima (1996 e 1997) discute esses efeitos apontando, a partir de minuciosa revisão acerca do tema, quais apresentam evidência científica ou não. O autor explica que como espécie florestal o eucalipto se comporta, neste aspecto, exatamente como qualquer outra espécie florestal e a questão de avaliar seu efeito sobre o balanço hídrico deve, evidentemente, levar em conta a precipitação anual média da região como regra principal para qualquer empreendimento agrícola.

A partir de 1990, o paradigma que se apresenta é que o manejo sustentável das plantações de eucalipto deve ser planejado com o objetivo de transformar as plantações em florestas. A paisagem em seu conjunto deve compreender pelo menos a preocupação em manter o potencial produtivo do solo assim como um certo nível de diversidade biológica e rendimento sustentado.

Tal visão, no setor florestal, adquire maior expressão através das normas ambientais associadas a obtenção do selo verde, como as normas da ISO (Internacional Organization for Standardization). As empresas florestais ao incorporarem essas normas, juntamente com outros sistemas de qualidade, passam a desenvolver mecanismos internos e externos de controle ambiental, uma vez que a 
qualidade total do produto corresponde pelo aumento da competitividade, notadamente no mercado externo.

Um dos mecanismos de controle utilizados para avaliar os impactos ambientais no setor florestal relacionados com a manutenção da produção de água em quantidade e qualidade têm sido a inserção da noção de monitoramento ambiental por meio da instrumentação de microbacias hidrográficas experimentais.

\subsection{A bacia hidrográfica como unidade de estudo}

O uso dos termos bacia, sub-bacia e microbacia hidrográfica parecem obedecer a uma certa escala espacial, entretanto não há um consenso entre a comunidade científica quanto a suas definições.

Admite-se geralmente, segundo Villela \& Mattos (1975), a bacia hidrográfica sendo contornada por um divisor, ou seja, a linha de separação que divide as precipitações que caem em bacias vizinhas e que encaminha o escoamento superficial resultante para um ou outro sistema fluvial. Os terrenos de uma bacia são, assim, delimitados por dois tipos de divisores de água: o divisor topográfico, que é condicionado pela topografia, fixa a área da qual provém o deflúvio superficial da bacia e o divisor de águas freático, que é determinado pela estrutura geológica dos terrenos e influenciado também pela topografia, estabelecendo os limites dos reservatórios de água subterrânea de onde é derivado o escoamento base da bacia.

A classificação apresentada por Strahler (1964) hierarquiza os canais formadores de uma bacia hidrográfica, quer sejam perenes, intermitentes ou efêmeros, em distintas ordens e, consequentemente, inviabiliza o uso do termo microbacia. Assim, são consideradas de primeira ordem as correntes formadoras, ou seja, os pequenos canais que não tenham tributários. Quando dois canais de primeira ordem se unem é formado um segmento de segunda ordem. Logo, a junção de dois canais de segunda ordem dá lugar àformação de um canal de terceira ordem e, assim, sucessivamente: dois canais de ordem $\mathbf{n}$ dão lugar a um canal de ordem $\mathbf{n}+\mathbf{1}$. 
O conceito de microbacia aparece em Moldan \& Cerny (1807) com o sentido de unidade da paisagem mais básica para estudar os processos hidrológicos por causa de sua homogeneidade com respeito æ̀ características hidrológicas e æ̀ características mínimas e necessárias para inferir métodos e maximizar o uso de diretas, e geralmente mais acuradas, medidas hidrológicas.

Esta linha de pensamento também é seguida por Lima \& Zakia (1998), onde a microbacia hidrográfica aparece enquanto uma unidade geomorfológica natural que expressa a menor manifestação física que permite quantificar, de forma integrada, o funcionamento da natureza.

"A bacia hidrográfica pode ser considerada um sistema geomorfológico aberto, recebendo energia do clima reinante sobre a bacia, e perdendo continuamente energia através do deflúvio podendo, assim, ser descrita em termos de variáveis interdependentes, as quais oscilam ao longo de um padrão, ou de uma média. Como tal, ela se encontra, mesmo quando não perturbada, em contínua flutuação, num estado de equilíbrio transacional ou dinâmico. Ou seja, a adição de energia, e a perda de energia no próprio sistema, encontram -se sempre em delicado balanço" (Lima, 1996).

A noção de microbacia enquanto unidade experimental está, em Villela \& Mattos (1975), apresentada como sendo aquela microbacia na qual se podem modificar suas condições naturais para que sejam estudados os efeitos dessas modificações sobre 0 ciclo hidrológico.

Em revisão realizada por Arcova (1996), o autor verifica que o uso de microbacias hidrográficas experimentais no monitoramento de impactos ambientais, especialmente àqueles relacionados ao regime hidrológico de bacias hidrográficas e uso da terra, é praticado há bastante tempo em vários países, sendo que o estudo pioneiro foi realizado na Suíça, em 1899, com o emprego do método hidrométrico de microbacias experimentais. 
Posteriormente, com a polêmica vivida nos Estados Unidos por volta de 1909 sobre a influência das florestas no cima, na saúde pública, no fluxo de nutrientes e na água do solo e riachos, que culminou em 1927 com a desastrosa inundação do Rio Mississippi, levou à instalação, por parte do Departamento de Agricultura desse país, do Laboratório Hidrológico de Coweeta, conforme relatos de Swank et al. (2001). O laboratório, localizado na floresta apalachiana em Ashville, Carolina do Norte, em função dos primeiros 50 anos de pesquisa sintetizou, em um livro intitulado Forest Hydrology and Ecology at Coweeta, as diretrizes básicas e resultados das pesquisas até então conduzidas em suas primeiras microbacias experimentais.

Ainda nos EUA, Reinhart (1958) relata que na Fernow Experimental Forest, em Virginia, cinco microbacias hidrográficas recobertas por floresta já eram monitoradas desde 1951 e avaliados o efeito de diferentes práticas de corte florestal no fluxo anual, mensal, máximo e mínimo. A qualidade da água, a precipitação e o conteúdo de água no solo, também foram monitorados.

Hamilton \& King (1983) registraram que quatro microbacias experimentais foram implementadas na década de 1955-65 no leste da África, oeste da África, Indonésia e Índia. Pesquisas nesta linha também foram iniciadas na década de 1970 nos trópicos e subtrópicos da Austrália e na Malásia. Em 1980 estudos foram iniciados em Taiwan.

Estas microbacias experimentais contam com as mais longas série de dados coletados e analisados, sendo que os efeitos mais estudados são àqueles relacionados com o corte da cobertura florestal, o reflorestamento e a substituição da vegetação sobre a produção e qualidade de água e também sobre a ciclagem de nutrientes.

No Brasil, os primeiros estudos conduzidos nessa perspectiva se iniciaram em 1982 no Parque Estadual da Serra do Mar, Núcleo Cunha (SP), no limite entre a Serra do mar e o Planalto Atlântico. Foram equipadas três microbacias experimentais recobertas com vegetação natural de Mata Atlântica que são monitoradas continuamente pelo Laboratório de Hidrologia Florestal Eng. Walter Emmerich, do Instituto Florestal de São Paulo, resultado da cooperação técnica entre os governos do Brasil e Japão a partir da Japan Internacional Cooperation Agency (JICA, 1980; 1986 apud Arcova, 1996). 
A partir de 1989, tem início a instalação de uma rede de microbacias experimentais em vários estados brasileiros, através do Programa de Monitoramento e Modelagem de Bacias Hidrográficas, coordenado pelo Instituto de Pesquisas e Estudos Florestais através do Laboratório de Hidrologia Florestal do Departamento de Ciências Florestais da ESALQ/USP, a qual passa a integrar a perspectiva do monitoramento ambiental de microbacias e o manejo florestal sustentável com base na identificação de critérios e Indicadores hidrológicos.

Através das medições das precipitações pluviométricas e dos deflúvios destas microbacias, vários autores (Andrade, 1991; Scardua, 1994; Azevedo, 1995; Câmara,1999) conduziram estudos sobre o balanço hídrico mensal e anual, processo de interceptação das chuvas pelas florestas, dinâmica da água no solo e ciclagem de nutrientes. De acordo com os resultados encontrados nessas microbacias experimentais, algumas variáveis foram selecionadas e testadas para o monitoramento da qualidade da água, cujos resultados podem ser utilizados como indicadores da qualidade do manejo florestal realizado, permitindo identificar os impactos gerados por esta atividade sobre os recursos hídricos e compará-los a ecossistemas naturais não perturbados.

\subsection{Caracterização hidrológica de microbacias e a identificação de indicadores}

Os métodos de calibração usados variam conforme as condições e objetivos do estudo, sendo os principais: a autocalibração, o método de bacias pareadas e 0 método da curva de dupla massa.

"A avaliação de qualquer alteração no regime hidrológico em uma bacia hidrográfica só pode ser eita caso exista um registro prévio de suas características hidrológicas, e que este período seja suficientemente longo para que se possa avaliar e quantificar a magnitude desta alteração. Estas comparações são possíveis quando correlacionam, na maioria das vezes, o deflúvio com outras variáveis hidrometeorológicas, 
sendo tal procedimento conhecido por calibração ou calibragem de uma bacia hidrográfica" (Arcova, 1996).

De acordo com Scardua (1994), a autocalibração utiliza uma única bacia, a qual é calibrada em função dela mesma, usando dados climáticos e hidrológicos.

"No método das bacias pareadas, uma variável do deflúvio de interesse da bacia a ser alterada é correlacionada com a mesma variável de interesse de uma segunda bacia adjacente ou vizinha, de condições similares àprimeira, denominada de bacia controle" (Arcova, 1996).

O uso de vários pares de bacias, tendo a característica do deflúvio de um determinado número de bacias tratadas, comparada com o deflúvio do mesmo número de bacias controle, também pode ocorrer para fins de calibragem.

Arcova (1996) afirma também que o método da curva de dupla massa pode ser usado tanto para bacias pareadas como para uma única bacia. Os totais acumulados da característica de interesse são plotados contra a variável controle em um gráfico do sistema cartesiano. Assim, o efeito causado pela alteração da vegetação é indicado pela mudança na declividade da curva.

O número de anos necessários para que se obtenha uma calibragem adequada entre bacias pareadas não é fixo, depende dos objetivos de estudo e da variabilidade dos dados utilizados.

"A acurácia a ser alcançada nos experimentos com microbacias é freqüentemente de difícil determinação. Na calibragem, uma equação de predição é definida e a ela está associado um erro de estimativa. Caso este erro seja suficientemente pequeno para ser aceito, significa que o grau de correlação entre as características das bacias e a precisão das observações é satisfatório" (Reigner, 1964).

Observa-se que as características mais utilizadas na calibragem estão relacionadas àquantidade do deflúvio. 
"Os deflúvios mensais, sazonais e anuais são as características de maior interesse em estudos de hidrologia florestal. Outras características, como o deflúvio diário, vazão máxima diária, vazão máxima de hidrogramas isolados, vazão mínima diária, volume de escoamento direto, escoamento base, entre outras, são também frequentes, assim como características inerentes ao regime de vazão" (Scardua ,1994).

Rodier (1976) e Whitehead \& Robinson (1993) levantaram a importância que as bacias hidrográficas, como unidades experimentais, poderiam apresentar para 0 monitoramento ambiental visando o manejo sustentável.

"O manejo ecossistêmico da bacia hidrográfica deve, portanto, considerar o aspecto do estado transacional e a contínua interdependência entre todos os fatores da bacia, a fim de que os impactos decorrentes das atividades antrópicas sejam sempre minimizados. O desenvolvimento de um programa de monitoramento florestal sustentável adequado passa, a princípio, pela identificação das seções dos canais na microbacia onde o monitoramento a longo prazo deverá ser implementado e, o monitoramento dessas áreas problema. Os indicadores daí apontados servem como norteadores das práticas de manejo no sítio florestal ou microbacia como um todo" (Lima, 1996).

"O desenvolvimento de um conjunto de indicadores facilmente mensuráveis que descrevam a condição e saúde das microbacias é essencial para a proteção e uso sustentável dos recursos hídricos" (He et al., 2000).

Do ponto de vista hidrológico, o manejo sustentável é aquele que segundo Lima \& Zakia (1998) permite a utilização dos recursos naturais de modo que não seja destruída a estabilidade do ecossistema, ou seja, a manutenção de seu funcionamento ecológico com base na perpetuação de seus processos hidrológicos, de sua capacidade natural de suporte, de sua diversidade biológica, na sua resiliência e na sua estabilidade. 
A partir de revisão realizada por Gunderson (2000), a resiliência ecológica pode ser definida como a quantidade de alteração que um ecossistema pode absorver sem mudar seu estado e depende, primeiramente, da diversidade dos grupos funcionais que definem sua composição e estrutura. Quando o ecossistema perde resiliência, ele se torna mais vulnerável a perturbações, que de outro modo seriam normalmente absorvidas.

Para Lima et al. (2002) o desenvolvimento de um conjunto de indicadores apropriados que permitam uma caracterização rápida, sensível, específica, confiável e economicamente viável das condições da microbacia para o planejamento e manejo requer a integração das ciências naturais, biológicas e sociais. Por isto deve considerar, ao mesmo tempo, a unidade de manejo florestal, a fazenda ou horto florestal, a microbacia, a região, o país e a biosfera com indicadores específicos para cada uma destas escalas.

"Um conjunto de indicadores selecionados deve produzir rapidamente, respostas sensíveis, específicas e de confiança que correspondam ao stress e, ao mesmo tempo, seja relativamente fácil ou barato para tornarse prático na decisão das intervenções de gestão e manejo nas escalas espacial e temporal" (He et al., 2000).

As Tabelas a seguir (1, 2 e 3 ) sugerem a identificação destas escalas e dos respectivos indicadores, no que diz respeito àproteção do solo e da água.

Tabela 1. Macro escala e indicadores da proteção do solo e da água para o manejo sustentável das plantações florestais

\begin{tabular}{ccc} 
Impacto ambiental & Possíveis causas & Indicadores \\
\hline Uso conflitivo da água & Desmatamento/reflorestamento & Balanço Hidrico regional \\
$\begin{array}{c}\text { Desfiguramento da } \\
\text { paisagem }\end{array}$ & Substituição de ecossistemas & Zoneamento Ecológico \\
naturais por plantações florestais & \\
\hline
\end{tabular}

Fonte: Lima \& Zakia (1998)

Ao nível macro, os elementos que contribuem para assegurar a manutenção dos processos hidrológicos, da capacidade de produção do sítio e do papel social da microbacia, estão contemplados nas políticas ambientais nas esferas Federal, Estadual 
e Municipal. Atualmente, essas fronteiras se ampliam na medida em que o capital externo fixa requisitos e normas de qualidade do produto e do ambiente, como é o caso das normas ISO visando àCertificação Ambiental.

As zonas ripárias atuam, por sua vez, como elemento integrador das escalas macro, e micro. Há que se ressaltar, também, o papel estratégico que os fragmentos florestais exercem na manutenção e ampliação de uma certa diversidade biológica na microbacia, quando interligados às matas ciliares.

"As faixas de vegetação ripária tem mostrado ser uma prática de manejo efetiva para o controle de algumas fontes não pontuais de poluentes, especialmente sedimentos" (Dillaha et al., 1989).

Tabela 2. Meso escala e indicadores da proteção do solo e da água para o manejo sustentável das plantações florestais

\begin{tabular}{ccc}
\hline Impacto ambiental & Possiveis causas & Indicadores \\
\hline & Destruição das zonas ripárias & Condiçōes de proteção vegetal \\
Degradação da & das zonas ripárias \\
microbacia & Sistema viário inadequado & Planejamento hidrológico das \\
& estradas e dos carreadores \\
& Compactação do solo & Taxa de infiltração
\end{tabular}

Fonte: Lima \& Zakia (1998)

$\mathrm{Na}$ escala micro processam-se as transformações que podem ser medidas e avaliadas no deflúvio do riacho, exercendo influência importante as zonas ripárias. 
Tabela 3. Micro escala e indicadores da proteção do solo e da água para o manejo sustentável das plantações florestais

\begin{tabular}{|c|c|c|}
\hline Tmpacto ambiental & Possíveis causas & Tndicadores \\
\hline $\begin{array}{l}\text { Quantidade e regime } \\
\text { de vazão d'água }\end{array}$ & Alteração da cobertura florestas & Mediçáo da vazáo \\
\hline $\begin{array}{l}\text { Eutrofização dos } \\
\text { cursos d'água e } \\
\text { reservatórios }\end{array}$ & Adubação, ausência & $\begin{array}{c}\text { Concentração de } \mathbf{N} \text { e P na mata } \\
\text { ciliar }\end{array}$ \\
\hline $\begin{array}{l}\text { Assoreamento dos } \\
\text { cursos d'água }\end{array}$ & Erosão e sedimentação & $\begin{array}{c}\text { Turbidez, concentração de } \\
\text { sedimentos }\end{array}$ \\
\hline Perda de nutrientes & $\begin{array}{c}\text { Erosão, colheita florestal, preparo } \\
\text { do solo }\end{array}$ & $\begin{array}{l}\text { Condutividade elétrica, } \\
\text { biogeoquímica da microbacia }\end{array}$ \\
\hline Material orgânico & $\begin{array}{c}\text { Decomposição de resíduos } \\
\text { florestais }\end{array}$ & Oxigênio dissolvido, cor \\
\hline
\end{tabular}

Fonte: Lima \& Zakia (1998)

Lima (1998) aponta que o monitoramento ambiental em microbacias, por intermédio da medição criteriosa de indicadores hidrológicos consistentes, constitui um instrumento importante para sinalizar as mudanças desejáveis ou indesejáveis que estejam ocorrendo no ecossistema, como conseqüência das práticas de manejo.

\begin{abstract}
"Pesquisas em pequenas bacias hidrográficas ajudam a determinar condições para uma agricultura sustentável baseada na estabilidade dos ciclos biogeoquímicos, retenção de água, nutrientes e substâncias dissolvidas, e minimização da erosão" (Moldan \& Cerny, 1807).
\end{abstract}

\title{
2.4 O Balanço Hídrico e avaliação do consumo de água pela floresta
}

Resultados experimentais avaliando a evapotranspiração, medida em termos da diferença entre a precipitação anual e o deflúvio anual de uma microbacia hidrográfica contendo cobertura florestal, permitem uma primeira avaliação global do consumo de água pela floresta em termos do efeito no balanço hídrico de uma bacia hidrográfica. 
Lima (1996) cita que a evapotranspiração se refere ao conjunto de perdas evaporativas de uma dada área vegetada, sendo controlada em grande parte por condições meteorológicas, isto é, sua taxa pode ser calculada a partir de dados de energia solar, velocidade do vento, temperatura do ar, umidade atmosférica e outros dados climáticos.

O balanço hídrico permite, assim, uma primeira avaliação, na escala macro, da disponibilidade hídrica de uma região, fornecendo informações importantes para o planejamento de atividades florestais e àquelas relacionadas ao consumo de água e mais propensas a um uso conflitivo.

Em microbacias florestadas, além da transpiração, as perdas de água podem ocorrer também por evaporação direta da água do solo, das superfícies líquidas e, quando chove, da interceptação.

A estimativa da evapotranspiração pode ser obtida por meio de métodos indiretos através de equações empíricas que incorporam variáveis meteorológicas. Dessas equações citam-se a de Thonrthwaite, Penman e Thornthwaite-Holzman.

O balanço hídrico, segundo o método de Thornthwaite \& Mather (1955), apresentado por Amorim Neto (1989), é um método climatológico que permite contabilizar a quantidade de água no solo disponível æ̀s plantas, além de indicar os períodos úmidos ou secos e considera a chuva e/ou irrigação como entrada de água no sistema, e a evapotranspiração como saída.

Normalmente, é predeterminada a capacidade máxima de retenção de água no solo, para permitir o cálculo do balanço hídrico regional mediante um sistema de contabilidade de água no solo.

"As associações entre as variações climáticas e a biogeoquímica do ecossistema ocorrem nas escalas espacial (horizonte do solo, microbacia) e temporal (evento, estação, ano) e integram uma grande variedade de componentes químicos e compartimentos do ecossistema: biológico, pedológico e hidrológico. Isso reflete a complexidade inerente dos sistemas naturais e oferece várias opções de indicadores de 
resposta das variações do ecossistema terrestre æ̀s variações na intensidade dos fatores ambientais. Portanto, mudanças nas flutuações climáticas podem alterar o funcionamento do ecossistema na escala da microbacia temporariamente ou permanentemente dependendo de sua resiliência a perturbações" (Courchesne et al., 2001).

Como método direto para verificação do consumo de água pela floresta e das perdas por evapotranspiração, o balanço hídrico anual da microbacia baseia-se no princípio de conservação de massa, sendo analisado pelas entradas e saídas de água do sistema.

Nas regiões de clima úmido o balanço hídrico anual da microbacia pode ser determinado através da seguinte Equação (1).

$$
P-E T-Q \pm \Delta S=0
$$

Onde,

$$
\begin{aligned}
& \mathrm{P}=\text { precipitação }(\mathrm{mm}) \\
& \mathrm{ET}=\text { evapotranspiração }(\mathrm{mm}) \\
& \mathrm{Q}=\text { Deflúvio }(\mathrm{mm}) \\
& \Delta S=\text { variação do armazenamento da água no solo }
\end{aligned}
$$

Devido às dificuldades na medição da variação do armazenamento da água no solo para o período monitorado, essa variação não será considerada.

Segundo Lima (1996), em estudos desenvolvidos em microbacias experimentais, considera-se o $\Delta S$ tendendo a zero partindo do princípio de que as variações que ocorrem no teor de umidade do solo durante 0 ano hídrico não variam significativamente no início do ano hídrico. Pela definição, $\Delta \mathbf{S}=\mathbf{S}_{\text {inicial }}-\mathbf{S}_{\text {final }}$, onde: $\mathbf{S}_{\text {inicial }}=$ armazenamento de água no solo no início do ano hídrico e $\mathbf{S}_{\text {final }}=$ armazenamento de água no solo no final do período. 
Com estas considerações, a equação do balanço hídrico para um ano hídrico em microbacias hidrográficas pode ser reduzida à

$$
\mathrm{ET}=\mathrm{P}-\mathrm{Q}
$$

Onde,

$$
\begin{aligned}
& \mathrm{ET}=\text { evapotranspiração }(\mathrm{mm}) \\
& \mathrm{P}=\operatorname{precipitação~}(\mathrm{mm}) \\
& \mathrm{Q}=\text { Deflúvio }(\mathrm{mm})
\end{aligned}
$$

Cicco et al. (1987) apud Rodríguez Anido (2002), ressaltam que a correta quantificação da entrada e da saída de água na microbacia é fundamental. A entrada pode ser obtida pela adequada instalação de pluviômetros espacialmente distribuídos e a saída de água da bacia, medida em estações fluviométricas equipadas com vertedores padronizados e aferidos em laboratório, o que permite a obtenção de valores da relação cota-vazão do curso d'água, dados pela curva-chave do vertedor. Quando isso não é possível, recomenda-se fazer a calibragem do vertedor já instalado na própria microbacia, por intermédio de medições de velocidade da água e a área da seção molhada do vertedor para diferentes cotas fluviométricas.

\subsection{Qualidade da água}

Em vista da complexidade de fatores que determinam a qualidade da água e a grande alternativa de variáveis usadas para descrever o status dos corpos hídricos em termos quantitativos, é difícil fornecer uma definição simples de qualidade da água.

"A qualidade do ambiente aquático é definida por uma série de concentrações, especificações e partículas físicas de substâncias orgânicas e inorgânicas, e a composição e estado da biota aquática encontrada num corpo hídrico. A qualidade do ambiente aquático mostra as variações temporais e espaciais em função dos fatores internos e externos do corpo hídrico" (Meybeck \& Helmer, 1992). 
Em revisão apresentada por Fulton \& West (2002) acerca dos impactos das atividades florestais na qualidade da água, os autores concluíram que há operações florestais potenciais para afetar desfavoravelmente a qualidade da água se as melhores práticas de manejo (Best Management Pratics) forem insuficientemente implementadas.

"A qualidade da água refere-se, então, a uma série de parâmetros físicos, químicos, biológicos e radiológicos que exercem influência direta na integridade da bacia hidrográfica que, por sua vez, está ligada a uma série de fatores de ordem natural e antrópica que devem ser observados conjuntamente. A integridade da microbacia envolve não só as práticas de conservação de solo como, também, a preservação de matas ciliares, a prevenção de compactação do solo, manutenção da biodiversidade e construção adequada de estradas" (Lima \& Zakia, 1998).

As fontes de poluição não pontuais estão relacionadas ao comportamento do clima, topografia, uso e cobertura da terra e æ̀s práticas de manejo. Mudanças na estrutura da paisagem resultarão em alterações nas taxas de carregamento dessas fontes incluindo a erosão, a sedimentação e concentração de nutrientes no deflúvio.

Outro aspecto a ser considerado é o padrão de referência com o qual comparar os resultados obtidos nas análises.

Lima (2002) recomenda que na ausência de tal classificação para microbacias, pode-se adotar os critérios propostos pelo Conselho Nacional de Meio Ambiente, que estabelece classes de qualidade das águas superficiais para os diferentes usos. Outro padrão existente é o elaborado pela Secretaria Federal de Controle da Poluição dos Estados Unidos, que estabeleceu o chamado "critério de qualidade de águas superficiais que podem servir como fontes de captação de água para abastecimento público".

As pesquisas desenvolvidas nas diversas microbacias experimentais monitoradas no Brasil tem permitido selecionar algumas variáveis para o monitoramento da qualidade da água e que podem ser utilizadas como indicadores da qualidade do 
manejo florestal realizado, permitindo inclusive, a detecção dos impactos gerados por essa atividade sobre os recursos hídricos.

Lima (2002) considera que a seleção das variáveis físicas e químicas envolve critérios essenciais para o manejo sustentável da plantação florestal. O primeiro destes, refere-se aos indicadores da manutenção da capacidade produtiva do local, traduzida em termos de saída de nutrientes e solo para a água do deflúvio: $\mathrm{N}, \mathrm{P}, \mathrm{K}, \mathrm{Ca}$, $\mathrm{Mg}$ e sedimentos em $\mathrm{Kg} / \mathrm{ha}$. Há os indicadores da manutenção dos processos hidrológicos da microbacia, representada pela manutenção do equilíbrio nas concentrações de $\mathrm{K}, \mathrm{Ca}, \mathrm{Mg}, \mathrm{Fe}, \mathrm{Na}, \mathrm{P}, \mathrm{N}$ e sedimentos em suspensão em mg/l. A condutividade elétrica e o pH também são parâmetros diretamente associados æ̀̀ concentrações de nutrientes. E, por fim, os indicadores da manutenção do equilíbrio do sistema aquático, representada por parâmetros limitantes para a biota aquática: $Q_{2}$ dissolvido, concentrações de sedimentos em suspensão, e dos nutrientes $\mathrm{N}$ e $\mathrm{P}$, turbidez, pH e temperatura

Câmara \& Lima (1999) ao avaliarem os efeitos do corte raso de uma plantação de eucalipto de 50 anos sobre a hidrologia de uma microbacia experimental, concluíram que, dentre os parâmetros químicos, foram considerados melhores indicadores, em primeiro lugar, o magnésio, seguido pelo cálcio. Já os parâmetros físicos apresentaram menor variação no período anterior ao corte e tiveram maiores alterações após o corte raso. Entre estes parâmetros, mostraram-se melhores indicadores a turbidez, a cor e a condutividade elétrica.

"Um dos indicadores da qualidade da água das bacias hidrográficas cobertas de vegetação é o teor e a quantidade de nutrientes que se encontram no deflúvio" (Schumacher \& Hoppe, 1998).

Deste modo, as variáveis apropriadas para atingir os objetivos propostos são apresentadas a seguir com respeito a suas origens, fontes, comportamentos e transformações no ecossistema aquático. Os padrões observados em águas naturais e poluídas e o papel da variável nos programas de avaliação são discutidos e, quando 
possível, comparados aos valores estabelecidos na resolução do CONAMA $n^{\circ} 20^{6}$, de 18/06/1986, para águas de Classe II.

As características descritas a seguir para cada parâmetro, quando não identificados os autores, referem-se a observações apresentadas nos trabalhos de Hem (1970) e Moldan \& Cerny (1994).

\subsubsection{Parâmetros Físicos}

Águas naturais possuem coloração que varia entre 0 e 200 unidades. Acima disso, indicam alto teor de matéria orgânica dissolvida. Valores de coloração abaixo de 5 unidades são encontrados em águas muito limpas. No Brasil aceita-se para água bruta, antes do tratamento para distribuição, valores de até $75 \mathrm{mg} \mathrm{Pt} / \mathrm{l}$.

A cor pode ser medida pela comparação de amostras com uma série de diluições de potássio cloroplatinado e cloreto cristalino de cobalto. As unidades são chamadas unidades platina-cobalto baseadas em $1 \mathrm{mgl}^{-1} \mathrm{PtCo}$. Minerais naturais como hidróxido de ferro e substâncias orgânicas como ácidos húmicos dão a cor real para a água. A cor aparente é causada por partículas coloridas e a refração e reflexão da luz nos particulados suspensos.

Valores elevados de turbidez, que é uma medida indireta da concentração de sedimentos, reduzem a fotossíntese da vegetação enraizada submersa e algas. Esse desenvolvimento reduzido de plantas pode, por sua vez, suprimir a produtividade de peixes e influenciar nas comunidades biológicas aquáticas. $O$ valor limite estabelecido é de até 100 UNT.

Alterações nas concentrações iônicas decorrentes da entrada de fertilizantes e defensivos podem causar alterações nos valores de condutividade. À medida que mais sólidos dissolvidos são adicionados, a condutividade específica da água aumenta. Concentrações elevadas podem indicar características corrosivas da água e grau de decomposição elevado e, valores reduzidos, uma acentuada produção primária.

6 Resolução CONAMA $n^{\circ} 20^{6}$, de 18 de jun. 1986. Disponível em http://www.mma.gov.br/port/conama/res/res86/res2086.html (23 de jan. 2003). 
Os sedimentos são os principais poluentes associados às operações florestais. Pesquisas realizadas em microbacias (Vital, 1996; Câmara, 1999 e Câmara \& Lima, 1999) indicam o aumento da concentração de sedimentos após o corte da floresta. A construção de estradas e o preparo intensivo do solo também têm grande potencial para causar erosão e sedimentação dos cursos d'água.

Águas de rios isentas de poluentes têm potencial Hidrogeniônico $(\mathrm{pH})$ variando de 6,5 a 8,5. A escala do $\mathrm{pH}$ varia de 0 a 14 (muito ácido a concentrações muito alcalinas), com o pH 7 apresentando uma condição neutra. De acordo com a resolução especificada, os níveis de $\mathrm{pH}$ devem variar de 6 a 9.

\subsubsection{Parâmetros químicos}

O nitrato é a principal forma de nitrogênio configurado encontrado nas águas. Concentrações de nitratos superiores a $5 \mathrm{mg} / \mathrm{l}$ demonstram condições sanitárias inadequadas, pois a principal fonte de nitrogênio nitrato são dejetos humanos e animais. Devido à competição com algas e outros vegetais, as águas naturais apresentam baixas concentrações de nitrato. Os valores recomendados são de 10 $\mathrm{mg} / \mathrm{l}$.

Distúrbios que venham a ocorrer na bacia hidrográfica, como retirada da floresta, podem provocar elevação das concentrações deste nutriente a níveis várias vezes superiores aos normais.

O fósforo total $(\mathrm{P})$ nas águas de bacias hidrográficas florestadas, resulta principalmente da lixiviação do solo e da rocha e da decomposição da matéria

orgânica. É, geralmente, um elemento limitante para o desenvolvimento das algas e consequentemente, controla a produtividade primária de um corpo hídrico. Na água, ele pode ser encontrado na forma orgânica ou inorgânica. A fertilização por adubos pode contribuir para a elevação da concentração de fósforo na água e é a causa principal da eutrofização. Como é um elemento ativamente tomado pelas plantas, o P é raramente encontrado em altas concentrações em águas doces superficiais. $\mathrm{O}$ valor limite recomendado é $0,025 \mathrm{mg} / \mathrm{l}$. 
Embora o potássio $\left(\mathrm{K}^{+}\right)$seja abundante na litosfera, como componente de minerais (feldspatos, micas etc.), sua concentração em águas naturais normalmente é baixa, especialmente devido à alta resistência dos feldspatos ao intemperismo. De qualquer modo, sais de $\mathrm{K}$ são amplamente usados nas indústrias e fertilizantes e entram, assim, nas águas doces através de descargas industriais e escoamento superficial por terras agricultáveis.

O cálcio $\left(\mathrm{Ca}^{2+}\right)$ é o principal cátion encontrado nas águas naturais, pois praticamente todas as rochas agem como fonte deste elemento. Nas regiões úmidas e nas regiões de ocorrência de rochas calcárias sua concentração é maior. Nas regiões semi-áridas as águas naturais contém, também, elevadas concentrações de Ca.

Os componentes do Ca são estáveis em água quando o dióxido de carbono está presente, mas os níveis de cálcio podem diminuir quando o carbonato de cálcio precipita por causa de um aumento na temperatura, atividade fotossintética ou perda do dióxido de carbono por causa de aumentos na pressão.

As principais fontes de magnésio $\left(\mathrm{Mg}^{2+}\right)$ para as águas naturais são os minerais ferro-magnesianos e algumas rochas carbonatíticas. Normalmente a concentração de $\mathrm{Mg}$ é sempre menor que a do Ca nas águas naturais. Assim como o $\mathrm{Ca}$, o os sais de Mg contribuem para o fenômeno da dureza da água.

\subsection{A compactação do solo e seus efeitos hidrológicos na microbacia}

Lima et al. (2002) afirmam que de todas as operações de manejo das plantações florestais, sem dúvida o preparo do solo e a colheita florestal são as que mais causam impactos ambientais, principalmente em termos de perdas de solo e do conseqüente assoreamento dos cursos d'água.

Seixas et al. (1998) verificaram, por sua vez, que a movimentação de máquinas e equipamentos na floresta resulta na compactação do solo.

"É possível relacionar os danos causados ao solo pelo tráfego de máquinas através de técnicas de predição de resposta do solo sob 
determinadas condições de carga e transmissão das tensões usando como parâmetros propriedades físicas do solo, umidade e características dos equipamentos" (Oliveira Júnior, 1998).

Para Silveira (1923) a vegetação exerce influência considerável sobre o regime hidrológico ao converter o escoamento superficial em escoamento subterrâneo, e interceptar parte da precipitação através dos galhos, folhas e caules. Outro aspecto importante é o do pastoreio de bovinos ser convenientemente conduzido, devendo existir uma rotação de culturas que evite qualquer degradação das propriedades físicohidrológicas do solo, conservando-se uma cobertura de gramíneas suficientemente desenvolvida.

"Em face de uma cobertura vegetal densa que amorteça o impacto das gotas de chuva e da baixa velocidade do escoamento superficial não é de se esperar grandes perdas de solo por erosão. Entretanto, quando há um excessivo pastoreio o solo torna-se descoberto, pela retirada da vegetação pelos animais, ocasionando, assim, um maior volume de enxurrada e um maior transporte de sedimentos, formando sulcos e, em estágios mais avançados, as voçorocas" (Bomfim, 2001).

Um dos indicadores do processo de degradação das pastagens apontados Bomfim (2001) é a redução da sua capacidade de suporte ao longo do tempo.

"A degradação das pastagens está associada a fatores ligados ao estabelecimento da forrageira e a práticas de manejo, sendo que algumas das causas mais importantes dessa degradação são: estabelecimento insatisfatório da pastagem decorrente da ausência ou uso inadequado de práticas de preparo, conservação, correção e/ou adubação do solo após o uso parcial ou prolongado de pastejo; escolha inadequada da espécie forrageira; ausência ou uso inadequado de adubação de manutenção; a ocorrência de pragas, doenças e plantas invasoras e ausência ou aplicação incorreta de práticas de conservação do solo" (Nascimento Júnior, 2001). 
O conhecimento da compactação em solos florestais e de sua relação com as atividades de plantio, manutenção e colheita, se torna, conforme as considerações apresentadas, um fator importante para o manejo adequado das condições físicas do solo a fim de melhorar a produção de água, em quantidade e qualidade, na escala da microbacia hidrográfica. A Tabela 2, citada anteriormente, situa a importância da avaliação da compactação do solo na escala meso, sua influência nas taxas de infiltração e sua relação com as práticas de manejo florestal, relacionando-a aos indicadores e impactos verificados nas demais escalas de análise.

"Torna-se necessário, portanto, uma abordagem mais sistêmica, para não usar o termo holístico, já meio desgastado, de manejo florestal, que inclua também a questão da escala, já que o manejo sustentável envolve múltiplas dimensões e múltiplas escalas" (Lima et al., 2002). 


\section{MATERIAL E MÉTODOS}

\section{1 Área de estudo}

O município de Bofete chamou-se antes Rio Bonito, tendo sido inicialmente um pequeno povoado conhecido por Samambaia, formado em torno de uma capela, já conhecido em 1846.

Regionalmente, "... a área em estudo teve as bases de sua evolução marcada por certa oscilação cultural e social entre Tatuí e Botucatu, se prendendo ao desenvolvimento das vias de comunicação e da economia agrícola" (Candido, 1987).

As primeiras formas de uso da terra referem-se às fazendas de cria pertencentes a padres da Companhia de Jesus, instaladas no início do século XVIII. A partir de então, com o cultivo de grãos e cereais, o município se pauta numa agricultura basicamente voltada para subsistência com uma ligeira ampliação da produção de café nos anos posteriores. Com a crise cafeeira, em 1902 e uma forte geada, em 1918, inicia uma fase de decadência progressiva que perdura até o final da década de 40 , marcada pelo mau estado e descuido da superfície plantada.

Candido (1987) registra que, por ocasião de sua visita ao município, em 1948, nem um só fazendeiro ou sitiante possuía jipe, automóvel ou estrada de automóvel em suas terras. Não se praticava adubação, não se utilizavam quaisquer produtos veterinários, não havia uma só máquina agrícola, a maior parte do transporte se fazia a carroça ou lombo de animal.

Em 1980 a tendência para a pecuária que implicava a transformação em pastagens das terras de cultivo encontra resistências pois a estabilização da pobreza, após a crise sofrida com o café, dependia da agricultura de semi-subsistência baseada 
na pequena propriedade. Com a incorporação progressiva dos agrupamentos rurais à esfera de influência da economia capitalista, o conseqüente aumento da dependência econômica condicionou um novo ritmo de trabalho e ambos condicionaram uma reorganização ecológica, que transforma as relações com o meio abrindo caminho para novos ajustes.

A inserção da eucaliptocultura no município, a partir da década de 1970, caracteriza as transformações paisagísticas e sócio-ambientais nesta nova fase. A recente fotografia aérea (Figura 1) obtida em 07/07/2000 (1:25.000), mostrada na figura a seguir, permite vislumbrar as rugosidades $^{7}$ presentes na paisagem em decorrência desta evolução.

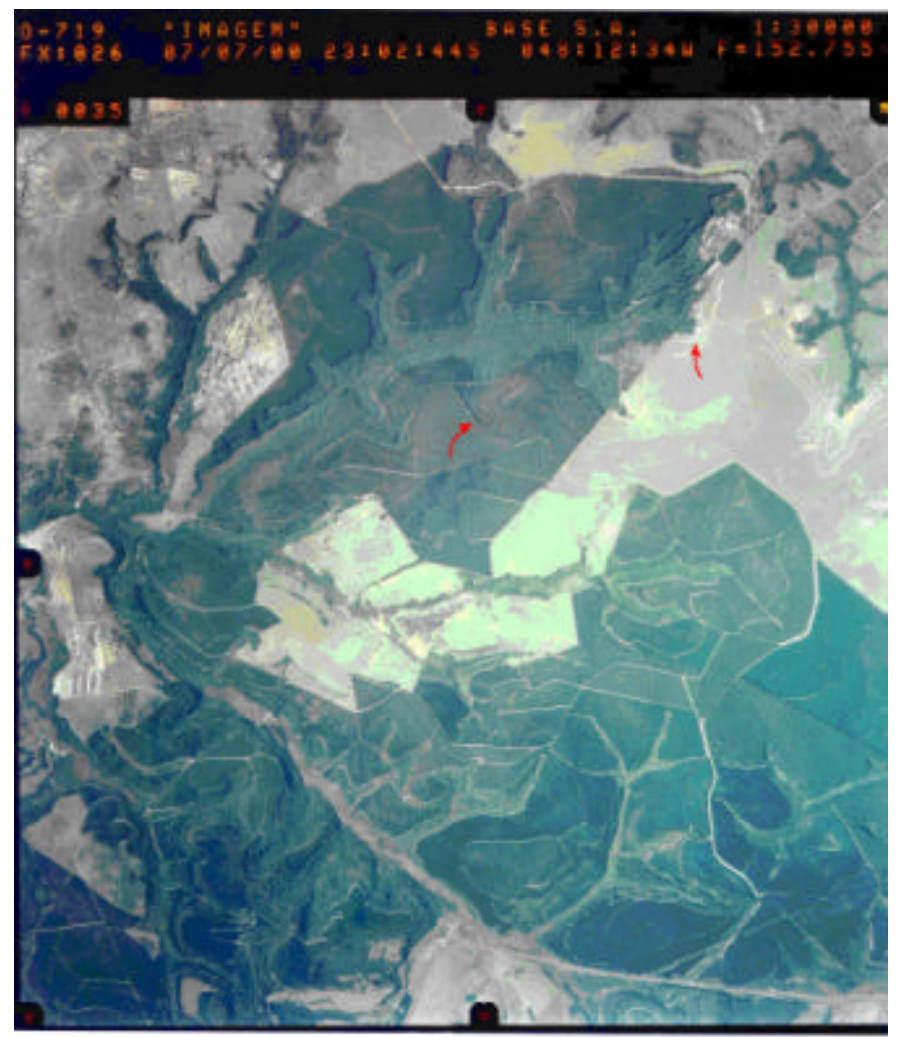

Figura 1 - Contexto espacial de inserção das microbacias na paisagem (escala macro)

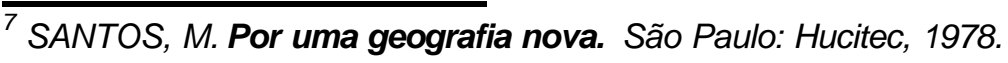


É marcante a diferença observada em relação a manutenção das áreas de preservação permanente e reserva legal nas duas formas predominantes de uso da terra. Logo, isso expressa a disparidade na aplicabilidade e materialização das leis ambientais brasileiras numa escala macro.

\subsection{Localização da área experimental}

As microbacias hidrográficas monitoradas localizam-se na mesma vertente da sub-bacia do Rio do Peixe e fazem parte da Fazenda Santa Terezinha, de propriedade da Eucatex/S.A. Situam-se no município de Bofete, na região centro-sul do estado de São Paulo (Figura 2), compreendendo as coordenadas geográficas: $23^{\circ} 04^{\prime}$ de Latitude Sul e 48¹3' de Longitude Oeste. A altitude média é de $600 \mathrm{~m}$.

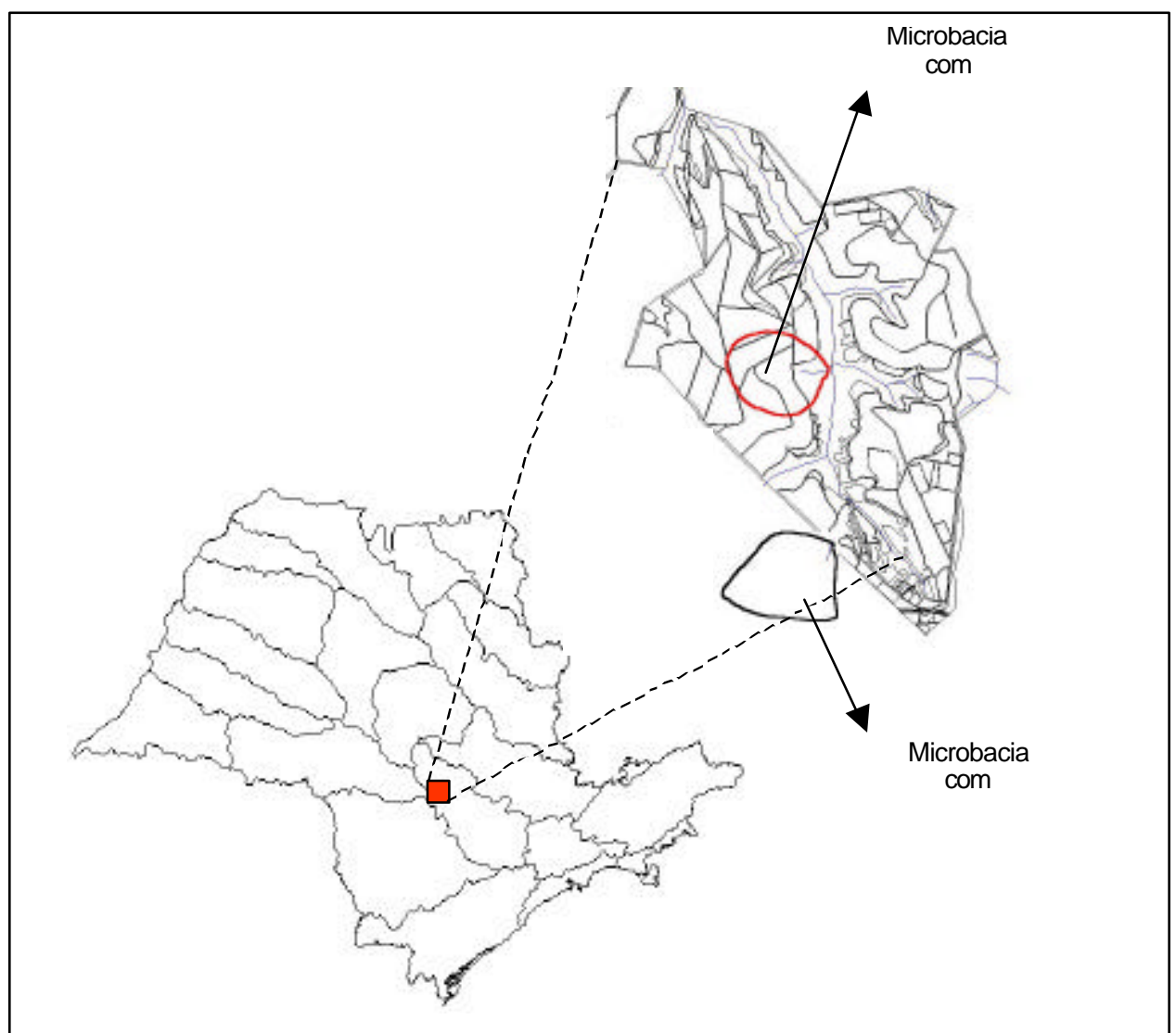

Figura 2 - Localização da área de estudo e identificação das microbacias Fonte: Figura adaptada de Ferraz (2002) 
A microbacia $E$ possui 50,23 ha de área de drenagem, com sua porção superior ocupada por eucalipto desde 1972. Os primeiros plantios foram de Eucalyptus saligna, para fins de serraria. A partir de 1990 a área foi reformada com o E. grandis, por sua melhor adaptação ao tipo de solo do local, sendo usado o espaçamento de 3,00 x 1,75 m. Atualmente, a microbacia representa um mosaico de talhões de eucalipto nas mais variadas idades e condições de sub-bosque, como é especificado no Quadro 1 e na Figura 3.

\begin{tabular}{|l|c|c|c|c|c|}
\hline Talhão & Área (ha) & $\begin{array}{c}\text { Data de } \\
\text { plantio }\end{array}$ & Espaçamento & $\begin{array}{c}\text { Última } \\
\text { intervenção }\end{array}$ & Atividade \\
\hline T-67 & 10,27 & Set/84 & $3,0 \times 1,5$ & Mai/93 & Corte \\
T-68 & 13,05 & Jul/90 & $3,0 \times 1,5$ & nov/2002 & Corte \\
T-69 & 15,20 & Jul/90 & $3,0 \times 1,5$ & Abr/98 & Desbrota mecânica \\
T-77 & 23,01 & Dez/90 & $3,0 \times 1,5$ & Abr/98 & Desbrota mecânica \\
T-78 & 29,20 & Dez/90 & $3,0 \times 1,5$ & Mar/97 & Corte \\
\hline
\end{tabular}

Quadro 1 - Características dos talhões que compõem a vegetação da microbacia E

Os talhões 67 e 68 apresentam um sub-bosque bem desenvolvido, composto principalmente por samambaias, indicando uma maior maturidade da floresta e uma ciclagem de nutrientes mais estabilizada. Nos demais talhões o fechamento da copa da floresta não permite a formação de sub-bosques. No geral, a maior fertilidade do solo da microbacia E, conforme mostram as análises físico-químicas, estão relacionadas a maior capacidade de ciclagem de nutrientes pela floresta. 


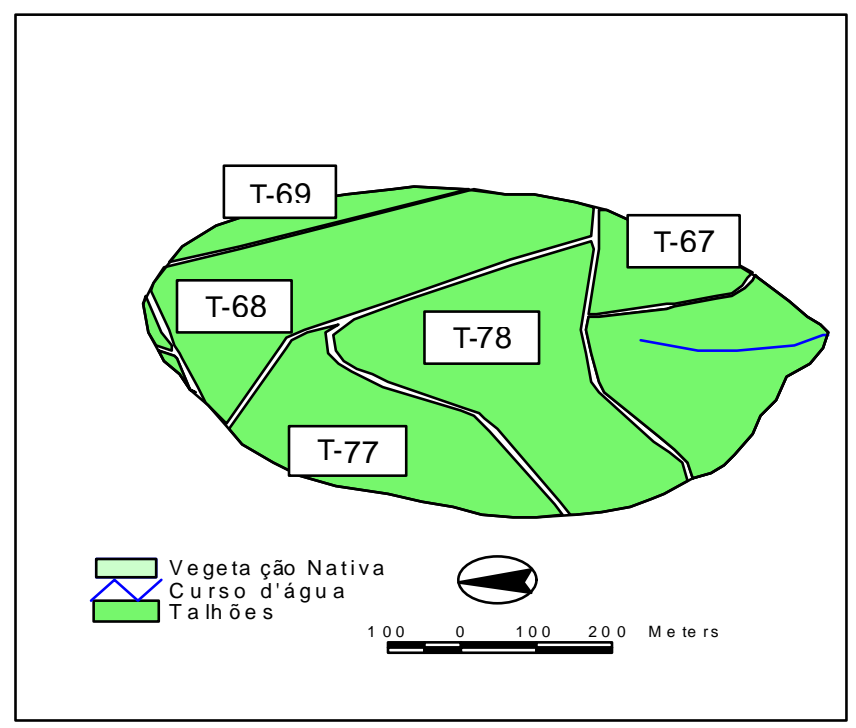

Figura 3 - Distribuição dos talhões na microbacia E

Margeando o curso d'água denominado de Córrego D'água Fria, encontra-se um cinturão de mata secundária nativa, contribuindo para a preservação da zona ripária e para a manutenção da integridade da microbacia.

A microbacia $P$, com área de drenagem de 60,80 ha, está coberta predominantemente por capim braquiária destinado àpecuária extensiva, uso tradicional da terra na região. A microbacia possui uma estreita faixa de mata ciliar ao longo das margens do canal, em estado visível de degradação. Esse fragmento é testemunha da vegetação nativa de cerrado que ocupava toda a área até o final da década de 70.

\subsection{Relevo}

Tendo como base a constância do escoamento, os cursos d'água das duas microbacias estudadas são classificados como perenes, ou seja, contém água durante todo o tempo. O lençol subterrâneo mantém uma alimentação contínua e não desce abaixo do leito do curso d'água, mesmo durante as secas mais severas. 
A área de drenagem, a forma da bacia, a ordem dos cursos d'água e a densidade de drenagem são elementos importantes na determinação do comportamento hidrológico das microbacias, apontados por Villela \& Mattos (1975) e descritos, para as microbacias estudadas, por Ferraz (2002), conforme detalhado a seguir.

\subsection{1 Área de drenagem}

A área drenagem de uma bacia é a área plana inclusa entre seus divisores topográficos e é o elemento básico para o cálculo das outras características físicas. É expressa em $\mathrm{Km}^{2}$ ou hectares.

\subsubsection{Forma}

A forma superficial de uma bacia hidrográfica é importante devido ao tempo de concentração, definido como o tempo, a partir do início da precipitação, que leva a água dos limites da bacia para chegar à saída da mesma. Existem vários índices utilizados para determinar a forma das bacias, procurando relacioná-las com formas geométricas conhecidas. Assim, o coeficiente de compacidade a relaciona com um círculo e o fator de forma com um retângulo.

\subsubsection{Coeficiente de compacidade $(\mathbf{K c})$}

Refere-se a relação entre o perímetro da bacia e a circunferência de um círculo de área igual àda bacia. Este coeficiente é um número admensional que varia com a forma da bacia, independentemente de seu tamanho, quanto mais irregular for a bacia, maior será o coeficiente de compacidade. Um coeficiente mínimo igual à unidade corresponderia a uma bacia circular. Obtém-se esse valor através da Fórmula 3.

$$
\mathrm{K}_{\mathrm{c}}=0,28 \underline{\mathrm{P}}_{\mathrm{A}}
$$

Onde,

$\mathrm{P}=$ perímetro da bacia em $\mathrm{Km}$

$\mathrm{A}=\mathrm{a}$ área da bacia em $\mathrm{Km}^{2}$

A microbacia com eucalipto, com área igual a 50,23 ha e perímetro igual a 2583 $\mathrm{m}$, tem um coeficiente de compacidade de 1,44. A microbacia com pastagem, por sua 
vez, com área igual a 60,80 ha e perímetro igual $3026 \mathrm{~m}$, possui um coeficiente de compacidade de 1,39, o que indica ser uma área não muito sujeita a enchentes.

\subsubsection{Fator de forma $(\mathbf{K f})$}

É a relação entre a largura média e o comprimento axial da bacia. Mede-se o comprimento da bacia $(L)$ quando se segue o curso d'água mais longo desde a desembocadura até a cabeceira mais distante na bacia e é obtida pela Fórmula 4.

$$
K_{f}=\underline{A}_{L^{2}}
$$

Onde,

$\mathrm{A}=\mathrm{a}$ área da bacia em $\mathrm{Km}^{2}$

O fator de forma também indica maior ou menor tendência para enchentes de uma bacia. Uma bacia com um fator de forma baixo é menos sujeita a enchentes que outra de mesmo tamanho porém com maior fator de forma.

As microbacias com eucalipto e pastagem apresentaram, respectivamente, 0,58 e 0,52, o que comprova o indicado pelo coeficiente de compacidade: microbacias não muito sujeitas a enchentes.

\subsubsection{Razão de elongação ( $\mathbf{R e})$}

É a relação entre o diâmetro do círculo de área igual à área da bacia e o comprimento do eixo da bacia, dada pela Fórmula 5.

$$
R_{e}=\frac{1,128 \times A^{0,5}}{L}
$$

Onde,

$\mathrm{A}=\mathrm{a}$ área da bacia em $\mathrm{Km}^{2}$

$\mathrm{L}=$ comprimento da bacia

Em bacias circulares, os afluentes atingem o curso d'água principal em praticamente um ponto, dando uma intensa vazão num só ponto. Nas bacias 
alongadas os afluentes se distribuem regularmente ao longo do rio principal. A probabilidade de uma chuva intensa cobrir toda uma bacia circular é maior que nas bacias alongadas, dando vazão intensa e maior probabilidade de enchente. Portanto, a tendência para maiores enchentes é tanto mais acentuada quanto mais próximo da unidade for o valor deste índice.

3.3.6 Índice de circularidade (IC)

É dado pela Fórmula 6.

$\mathrm{I}_{\mathrm{C}}=\frac{12,57^{\mathrm{A}}}{\mathrm{P}^{2}}$

Onde,

$\mathrm{I}_{\mathrm{C}} \leq 1$

$\mathrm{A}=\mathrm{a}$ área da bacia em $\mathrm{km}^{2}$

$\mathrm{P}=$ perímetro da bacia em $\mathrm{km}$

Simultaneamente ao índice de circularidade, o coeficiente de compacidade e a razão de elongação também tendem para a unidade àmedida que a bacia se aproxima da forma circular.

\subsubsection{Ordem dos rios}

As microbacias estudadas são consideradas de primeira ordem, pois são pequenos canais que não têm tributários, segundo a classificação apresentada por Strahler (1964).

\subsubsection{Densidade de drenagem ( $\mathbf{D d})$}

Indica o grau de desenvolvimento de um sistema de drenagem e varia inversamente com a extensão do escoamento superficial, fornecendo uma indicação da eficiência da drenagem da bacia. Esse índice varia de $0.5 \mathrm{Km} / \mathrm{Km}^{2}$, para bacia com drenagem pobre, a 3,5 ou mais, para bacias excepcionalmente bem drenadas.

A microbacia $E$ apresenta uma densidade de drenagem na ordem de 0,52 $\mathrm{Km} / \mathrm{Km}^{2}$. A microbacia $\mathrm{P}$, por sua vez, apresenta $0,27 \mathrm{Km} / \mathrm{Km}^{2}$ de densidade de 
drenagem. Os valores encontrados indicam que ambas as microbacias apresentam drenagem fraca.

Resumidamente, as principais características morfométricas das microbacias, estão apresentadas no Quadro 2.

O relevo de uma bacia hidrográfica tem grande influência sobre os fatores meteorológicos e hidrológicos, pois a velocidade do escoamento superficial é determinada pela declividade do terreno, enquanto que a temperatura, a precipitação e a evaporação dentre outros, são funções da altitude da bacia.

\begin{tabular}{|l|c|c|}
\hline \multicolumn{1}{|c|}{ Características } & Eucalipto & Pasto \\
\hline Área de drenagem (ha) & 50,23 & 60,80 \\
Perímetro (m) & 2583 & 3026 \\
Comp. canal principal $(\mathrm{m})$ & 263 & 170 \\
Maior eixo $(\mathrm{m})$ & 925 & 1080 \\
Menor eixo (m) & 749 & 910 \\
Índice de circularidade & 0,94 & 0,83 \\
Coeficiente de compacidade & 1,44 & 1,39 \\
Razão de elongação & 0,74 & 0,95 \\
Fator de forma & 0,58 & 0,52 \\
Ordem dos cursos d'água & $1^{\underline{a}}$ ordem & $1^{\underline{a}}$ ordem \\
Densidade de drenagem & $0.52 \mathrm{~km} / \mathrm{km}^{2}$ & $0,27 \mathrm{~km} / \mathrm{km}^{2}$ \\
\hline
\end{tabular}

Quadro 2 - Características morfométricas das microbacias da Fazenda Santa Terezinha

Fonte: Ferraz (2002)

A magnitude dos picos de enchente e a maior ou a menor oportunidade de infiltração e susceptibilidade para erosão dependem da rapidez com que ocorre o escoamento sobre os terrenos da bacia.

Observa-se na Figura 4 que a variação altimétrica na microbacia E é de 70m. 


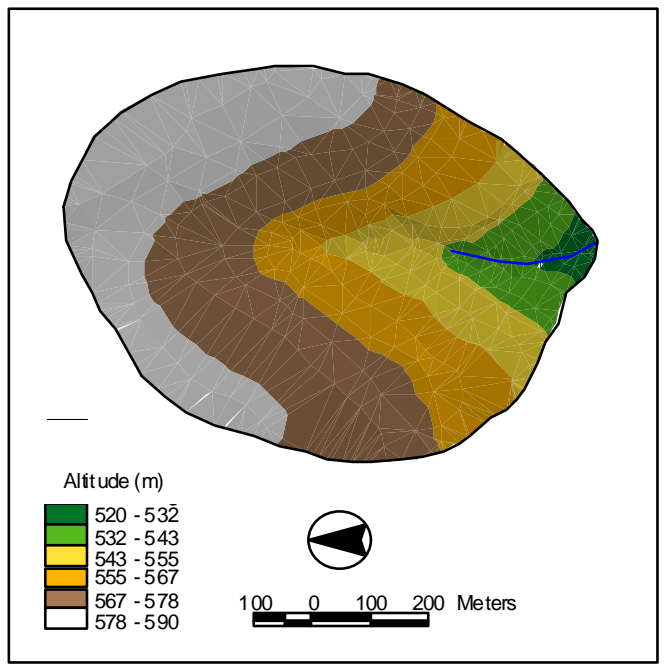

Figura 4 - Variação altimétrica na microbacia $\mathrm{E}$

Para a microbacia P, esta variação é de 63m (Figura 5).

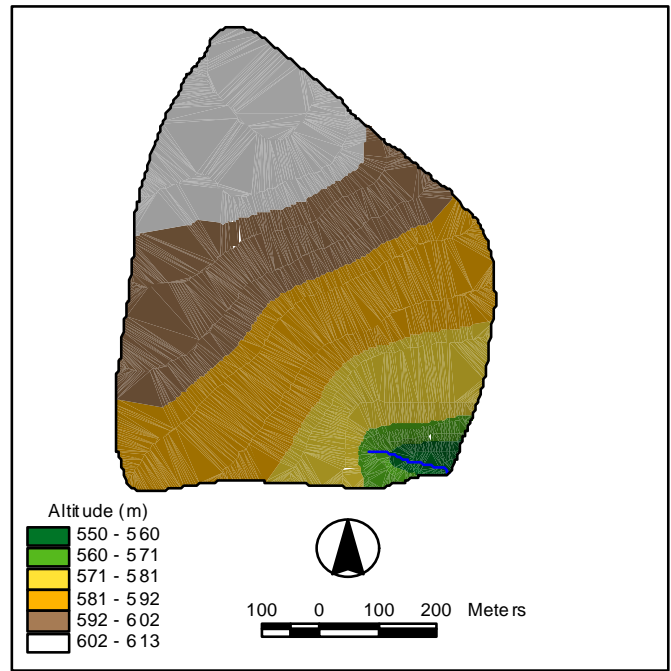

Figura 5 - Variação altimétrica determinada pelo Modelo Digital do Terreno para a microbacia $P$

Fonte: (Ferraz, 2002)

\subsection{Clima}

O clima regional é do tipo mesotérmico úmido (Cfa), conforme classificação de Köeppen, com precipitação média mensal do mês mais seco entre 30 e 60 mm, sendo 
a temperatura mínima anual $18,38^{\circ} \mathrm{C}$ e a precipitação média, extraída de uma média de 20 anos de dados (1980 a 1999), de 1440 mm (SIGRH, 2001).

Para a caracterização das condições climáticas locais, as medições da temperatura, pluviosidade e umidade relativa do ar foram feitas através de equipamentos instalados numa única estação meteorológica. Por esse motivo, a fim de proceder àcalibração, a variação geográfica destes fatores de uma microbacia para a outra foi considerada desprezível, dada a proximidade de ambas (cerca de 1.000 metros), e àsemelhança das feições geomorfológicas.

As tendências gerais para o comportamento da variação da temperatura e umidade descritas em 1975 por Villela \& Mattos, sugerem que, "no caso da temperatura, a variação é produzida pela flutuação diária da radiação solar incidente. A temperatura começa a se elevar ao nascer do sol e atinge seu máximo 1 a 3 horas depois do sol ter atingido sua altitude máxima. As temperaturas mínimas ocorrem normalmente por volta do nascer do sol. Durante a noite, quando a radiação solar está ausente, a temperatura é afetada somente por esfriamento radiante. $\mathrm{O}$ intervalo diurno de temperaturas, isto é, a diferença entre a máxima e a mínima diária, é afetado pelo estado do céu. Em dias nebulosos a temperatura máxima é menor por causa da redução da insolação. Por outro lado, a mínima é maior porque as nuvens reduzem a perda de radiação. A temperatura média diária é normalmente determinada pela média aritmética entre as temperaturas máxima e mínima".

Os dados de umidade e temperatura coletados para o período de setembro de 2001 a agosto de 2002, indicam uma ligeira variação desses fatores ao longo do período estudado, mas que corresponde às tendências gerais. Essa variação pode ser mais bem visualizada na Figura 6 . 


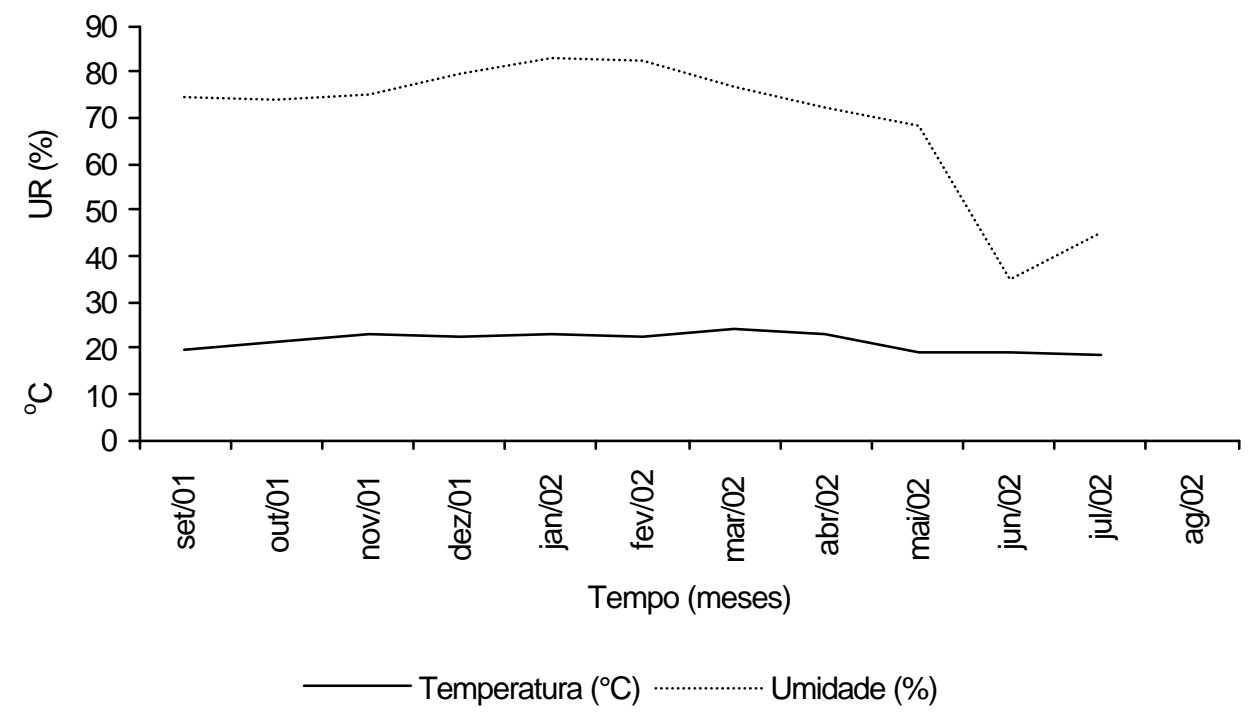

Figura 6 - Variação da Temperatura e Umidade Relativa do Ar no período de setembro/01 a agosto/02

As temperaturas médias mensais variaram de $24,31^{\circ} \mathrm{C}$, em março, a $18,38{ }^{\circ} \mathrm{C}$ em julho, observando-se uma amplitude de variação de $5,93^{\circ} \mathrm{C}$ no período monitorado.

\subsection{Vegetação}

"A formação florestal nativa predominante na Fazenda Santa Terezinha é a Floresta Estacional Semidecidual, também denominada por Floresta Mesófila Semidecidual e genericamente conhecida por Mata de Planalto" (Rizzini, 1963).

Albuquerque \& Rodrigues (2000) citam que a vegetação de Bofete ocorre em uma condição ecotonal onde a matriz é floresta Estacional Semidecidual, com ocorrência de elementos de floresta Ombrófila Densa e Mista e Cerrado Senso Lato.

"Estas Matas de Planalto ocupam uma área expressiva do sudeste do Brasil, ao longo dos estados de São Paulo, parte do Paraná, Minas Gerais, Mato Grosso, Goiás e, em menor proporção, os Estados do Espírito Santo e Rio de Janeiro até o sul da Bahia. Constitui-se em uma formação descontínua que em alguns trechos entremeia campos, 
campos rupestres, cerrados, cerradões e matas ciliares. Ocorrem em áreas de clima e solos variados, com característica climática apresentando invernos secos e frios e verões úmidos e quentes. $A$ deciduidade das folhas acentua-se nos meses mais frios para um grande número de espécies, particularmente æ̀ que pertencem aos estratos superiores" (Leitão Filho, 1982).

$\mathrm{Na}$ escala meso, verificou-se que a maioria dos fragmentos de vegetação nativa que possuem nascentes e cursos d'água está interligada a outros fragmentos dentro da fazenda, demonstrando a qualidade destes ambientes e a importância da sua conservação em termos de corredores de avifauna e fluxo gênico, o que propicia a manutenção de uma certa diversidade biológica na microbacia sob eucalipto.

Dário \& Almeida (2000) afirmam que em qualquer ambiente estudado, os núcleos de dispersão exercem papel importante para a conservação da biodiversidade. Se forem implantadas faixas (corredores) interligando os fragmentos (núcleos de dispersão), essas faixas sofrerão influências diretas destes núcleos de dispersão.

Wilson \& Lindenmayer (1996) sugerem que os corredores de vegetação natural podem complementar a cadeia de reserva existente aumentando a área efetiva de habitat para a fauna e com isso, os vínculos entre a fauna e o habitat. No entanto, esses corredores podem não ser efetivos para a conservação de todas as espécies e o estabelecimento destes não é a solução para todos os problemas de conservação da biodiversidade. Antes, devem ser utilizados como uma das estratégias para mitigar os efeitos de áreas agrícolas e de plantios florestais sobre a fauna e a flora.

A cobertura vegetal da microbacia E pode ser visualizada na Figura (7) a seguir, tanto a floresta plantada (Talhão-67), quanto a mata ciliar que margeia o Córrego D'Água Fria. 


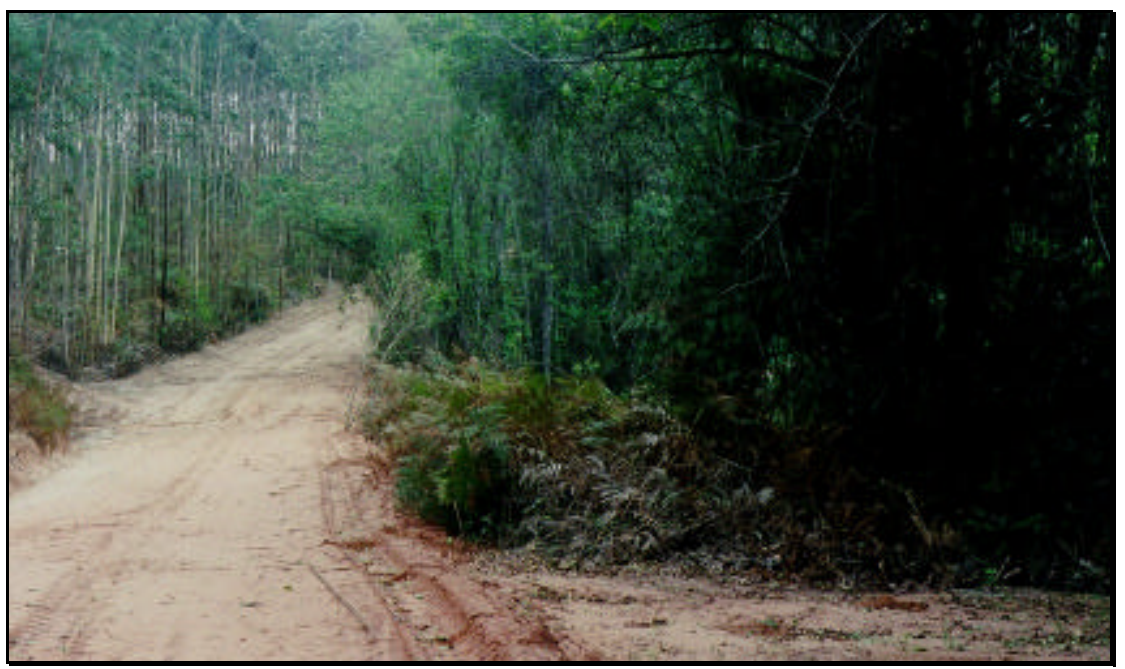

Figura 7 - Eucalipto (esquerda) e mata ciliar (direita), na microbacia $\mathrm{E}$

Na microbacia $P$, a presença da mata ciliar se restringe æ̀s margens do curso d'água, o restante da cobertura vegetal é a gramínea Brachiaria decumbens (Figuras 8 e 9).

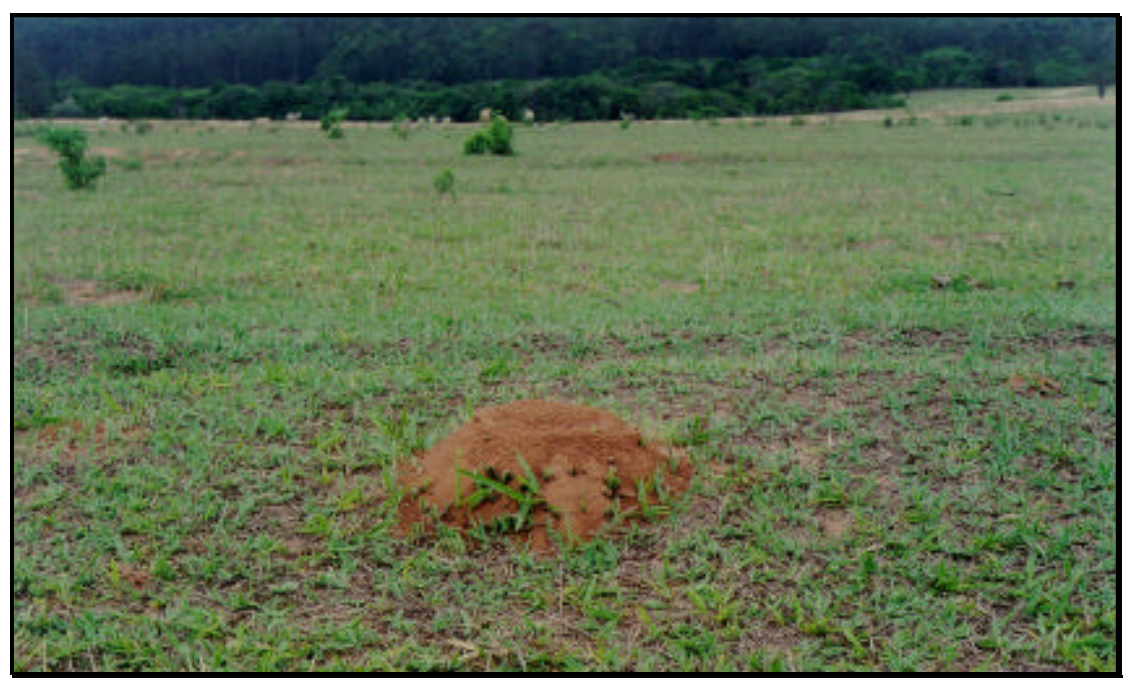

Figura 8 - Cobertura vegetal da microbacia P 


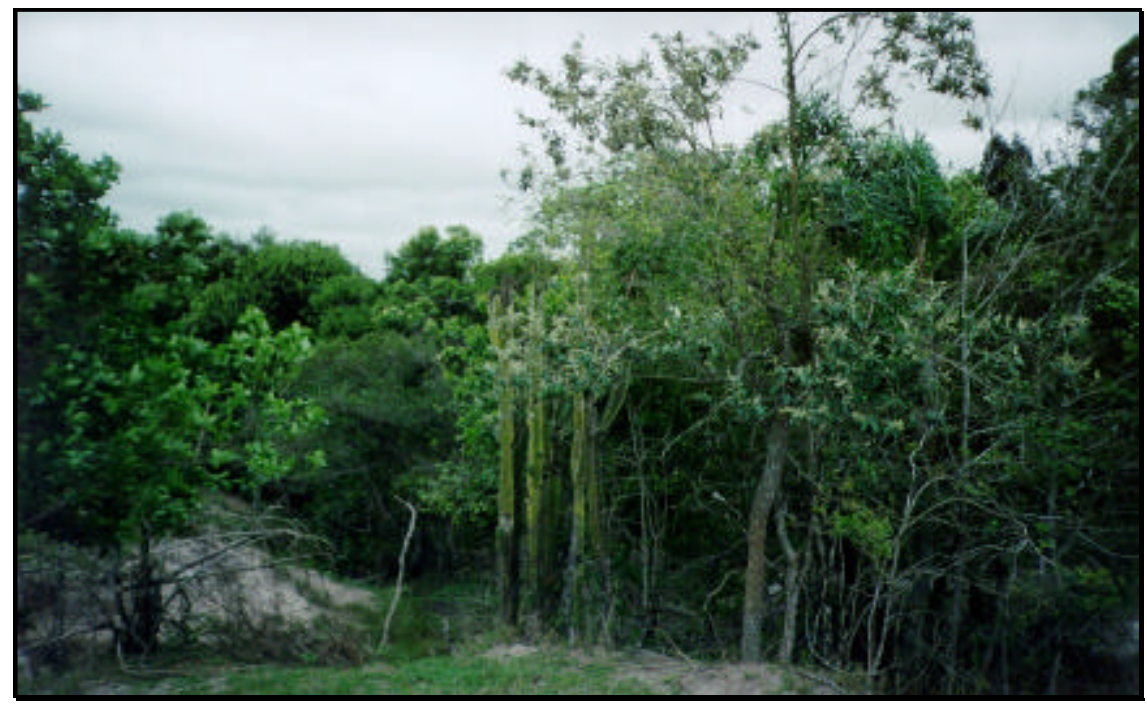

Figura 9 - Aspecto da mata ciliar presente na microbacia $\mathrm{P}$

\subsection{Geologia}

O mapa geológico do Estado de São Paulo (IPT, 1981) classifica o embasamento geológico da área em estudo como pertence à Formação Pirambóia, litologicamente caracterizada por uma sucessão de camadas arenosas, com predominância de cores avermelhadas.

Os arenitos são geralmente de granulação média a fina, possuindo fração argilosa maior na parte inferior que na superior da formação. Predomina a estratificação plano-paralela, com marcas ou não de ondas, podendo apresentar camadas estreitas de materiais de textura mais fina como siltitos e argilitos. As características litológicas e estruturais indicam ambiente de deposição continental úmido, oxidante, associado a canais fluviais meandrantes (Pessotti, 1998).

\subsection{Solos e geomorfologia}

Pessotti (1998), em levantamento semidetalhado dos solos da Fazenda Santa Terezinha, verificou que os solos encontrados são todos de textura arenosa, com predominância de Latossolos Vermelho-Amarelo de textura médio arenosa; Areias 
Quartzozas com tendência ou não a podzolização, ocorrendo em formas de relevo suave ondulada e ondulada; e Podozólicos Vermelho-Amarelos de textura arenosa sobre média e Vermelho-Escuro, em menor proporção, ocupando formas onduladas do relevo.

As amostras de solo foram coletadas entre 5 a $17,5 \mathrm{~cm}$ de profundidade nas parcelas instaladas para amostragem da densidade e compactação do solo. A partir das amostras coletadas para determinação da densidade, separou-se uma amostra composta para cada microbacia. As amostras foram acondicionadas em sacos plásticos e enviadas ao laboratório a fim de proceder as análises.

As análises físico-químicas do solo foram realizadas no Laboratório de Ecologia do Departamento de Ciências Florestais da ESALQ/USP, conforme metodologia apontada por Raij et al. (2001). Os resultados e os métodos de análise utilizados são apresentados nas Tabelas 4, e 5 e no Quadro 3.

A análise textural foi determinada por sedimentação em cilindro de Koettgen, após dispersão e agitação mecânica por 16 horas utilizando como dispersante uma solução de $\mathrm{NaOH}$ com hexametafosfato de sódio.

A análise granulométrica teve como objetivo separar e determinar as partículas de diferentes tamanhos para os solos das microbacias. As frações areia grossa, areia média e areia fina foram separadas por tamisação em peneiras de malha igual a 0,5; 0,25 e $0,10 \mathrm{~mm}$ de diâmetro, respectivamente. A fração argila foi determinada pelo hidrômetro de Boyoucos e a fração silte, determinada como a diferença entre o peso de terra fina seca em estufa menos o peso total mais argila.

Tabela 4. Características Físicas do solo das microbacias

\begin{tabular}{lcccccr}
\hline Microbacia & $\begin{array}{c}\text { Argila } \\
(\%)\end{array}$ & $\begin{array}{c}\text { Silte } \\
(\%)\end{array}$ & Total & Grossa & $\begin{array}{c}\text { Areia (\%) } \\
\text { Média }\end{array}$ & Fina \\
\hline Pasto & 6 & 0 & 94 & 3 & 27 & 64 \\
Eucalipto & 8 & 3 & 89 & 4 & 33 & 52 \\
\hline
\end{tabular}

Os parâmetros químicos e os métodos usados para sua determinação estão apresentados no Quadro 3 e seus respectivos valores, na Tabela 4. 


\begin{tabular}{|l|c|}
\hline \multicolumn{1}{|c|}{ Parâmetro } & Método \\
\hline PH & Potenciométrico \\
Mat. Orgânica & Colorimétrico \\
Fósforo & Colorimétrico ou espectrofotométrico \\
Potássio & Espectrofotométrico ou fotométrico \\
Cálcio & Espectrofotométrico \\
Magnésio & Espectrofotométrico \\
Alumínio & Titulométrico \\
Acidez Potencial $(\mathrm{H}+\mathrm{Al})$ & Indireto/potenciomét rico $(\mathrm{pH} \mathrm{SMP})$ \\
Soma das Bases $-\mathrm{SB}$ & Cálculo $\left(\mathrm{K}^{+}+\mathrm{Ca}{ }^{2+}+\mathrm{Mg}^{2+}\right)$ \\
Cap.Troca Catiônica - T & Cálculo $([\mathrm{SB}+(\mathrm{H}+\mathrm{Al})])$ \\
Saturação de Bases $-\mathrm{V}$ & Cálculo $((\mathrm{S} / \mathrm{T}) \times 100)$ \\
\hline
\end{tabular}

Quadro 3 - Métodos utilizados na determinação dos parâmetros químicos do solo

Tabela 5. Parâmetros químicos do solo das microbacias

\begin{tabular}{|c|c|c|c|c|c|c|c|c|c|c|}
\hline Microbacia & $\begin{array}{c}\mathrm{P} \\
\mathrm{Mgdm}^{-3}\end{array}$ & $\begin{array}{l}\text { M.O. } \\
\mathrm{g} \mathrm{dm}^{-3}\end{array}$ & $\begin{array}{c}\mathrm{pH} \\
\mathrm{CaCl} 2\end{array}$ & $\mathrm{~K}$ & $\mathrm{Ca}$ & $\begin{array}{r}\mathrm{Mg} \\
\mathrm{mr}\end{array}$ & $\begin{array}{l}\mathrm{H}+\mathrm{Al} \\
\mathrm{dm}^{-3}\end{array}$ & $\overline{A l}$ & SB & $\begin{array}{l}\mathrm{T} \\
\mathrm{T}\end{array}$ \\
\hline Pasto & 3 & 6 & 4,3 & 0,7 & 3 & 2 & 18 & 3 & 6 & 24 \\
\hline Eucalipto & 4 & 12 & 3,9 & 0,3 & 2 & 2 & 45 & 13 & 4 & 49 \\
\hline
\end{tabular}

Os solos arenosos (menos de $10 \%$ de argila), condicionam uma drenagem excessiva e diminuta retenção de água, limitando-os æ̀ culturas, de um modo geral (Silva, 1995).

"Desagregação, aeração e drenagem boas, assim como fácil subsolagem são características de solos arenosos. Por outro lado, tais solos são em geral muito desagregados e abertos, não possuindo capacidade adequada de adsorção e de manutenção de umidade e de nutrientes. Portanto, são comumente secos, insuficientemente férteis e carentes de granulação" (Brady, 1989).

Em geral, para solos mais arenosos e deficientes no fornecimento de água, observa-se, mais freqüentemente, maiores respostas àadubação (Raij et al., 1996). 
No aspecto químico, a maior parte da área está sob domínio de solos com baixos teores de nutrientes essenciais, considerando-se as exigências nutricionais do eucalipto, o que aponta para a necessidade de adubação nas diversas fases do ciclo da floresta, bem como a necessidade de uma atenção especial para as pastagens. Esta situação deve ser considerada juntamente com os diferentes estágios que a floresta apresenta.

"A magnitude dos fluxos de nutrientes via ciclagem aumenta consideravelmente na fase de fechamento das copas, quando as partes inferiores começam a perder suas folhas devido às limitações de luminosidade. Antes da queda das folhas, grande parte dos nutrientes migram para os tecidos mais jovens das árvores. Com a deposição de folhas, galhos e outros resíduos vegetais, forma-se a serapilheira sobre a superfície do solo que, ao se decompor, libera nutrientes para as árvores, os quais são imediatamente aproveitados pelo emaranhado de radicelas que se misturam com os componentes da serapilheira. Sob tais condições, quanto mais velho for o povoamento florestal, menor sua dependência da fertilização, pois a ciclagem de nutrientes, por si só, atende grande parte das exigências nutricionais das árvores" (Raij et al., 1996).

\subsection{Fluviometria e pluviometria}

Para efeito da quantificação do balanço hídrico anual das microbacias experimentais, foram feitas medições contínuas da precipitação pluviométrica e do deflúvio.

A coleta dos dados analisados na pesquisa, abrangeu um período de 24 meses, estendendo-se de novembro de 2000 a outubro de 2002, para as medições do deflúvio e da precipitação. No que diz respeito à qualidade da água do deflúvio, a série de dados analisados compreendeu 12 meses (novembro de 2001 a outubro de 2002). 


\subsubsection{Medição do deflúvio}

Ambas as microbacias foram instrumentadas com uma estação linimétrica, conforme ilustram as Figuras 10 e 11, composta de tanque de sedimentação e tranqüilização de fluxo, vertedor misto, linígrafo digital, régua linimétrica e 2 garrafas coletoras de amostra do escoamento direto, instaladas em diferentes alturas no poço tranquilizador.

A parede de concreto onde se fixou o vertedor foi construída transversalmente ao curso d'água e com profundidade suficiente para atingir a camada de impedimento do subsolo, de modo a vedar a passagem de água por baixo e lateralmente àestrutura.

O vertedor misto é uma estrutura com comportamento hidráulico denominado de crista curta, com seção transversal composta, tendo formato triangular com ângulo de $150^{\circ}$ em sua parte inferior e formato retangular em sua parte superior. Essa estrutura tem capacidade para medir vazões entre 3 e $1800 \mathrm{l} / \mathrm{s}$.

No ponto escolhido para instalação do vertedor foi construído um tanque de concreto onde a água do riacho se estabiliza antes de passar pela seção do vertedor, de modo a anular os efeitos da turbulência da água. Nesse tanque de estabilização foi colocada uma régua graduada, para medir o nível da água, de modo a possibilitar o ajuste do linígrafo.

Cada estação foi dimensionada de modo a adequar as feições geomorfológicas das seções onde foram construídas. 


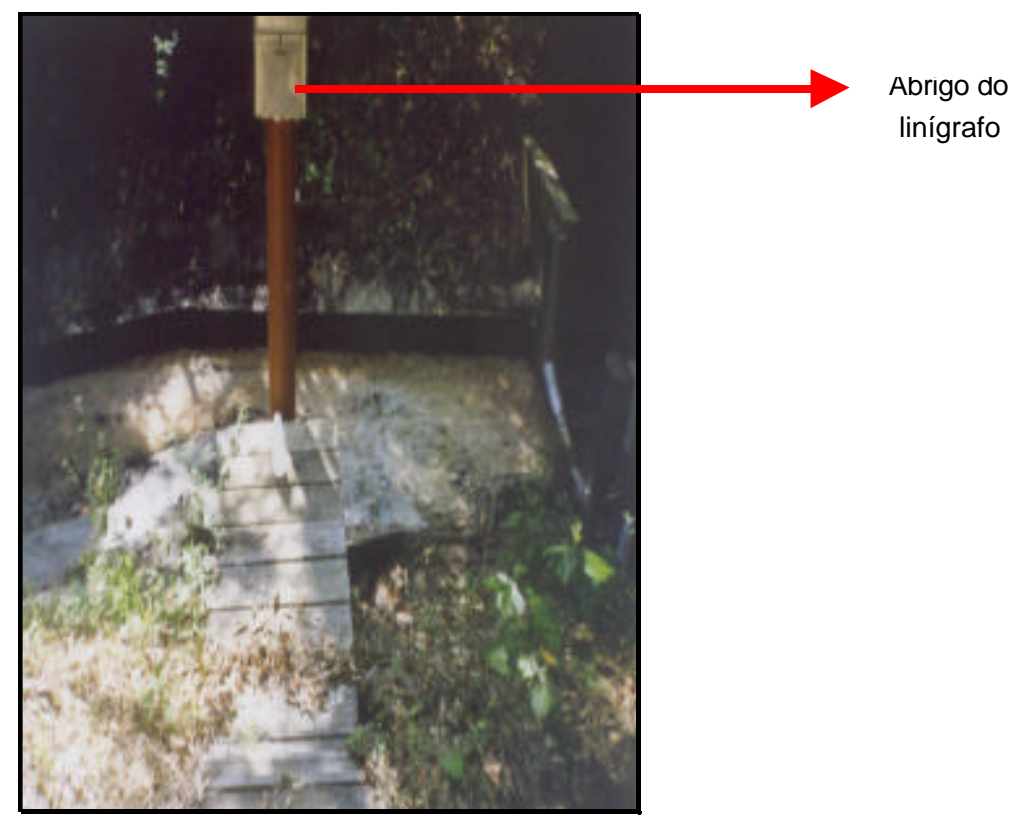

Figura 10 - Visão lateral do vertedor instalado na microbacia $P$

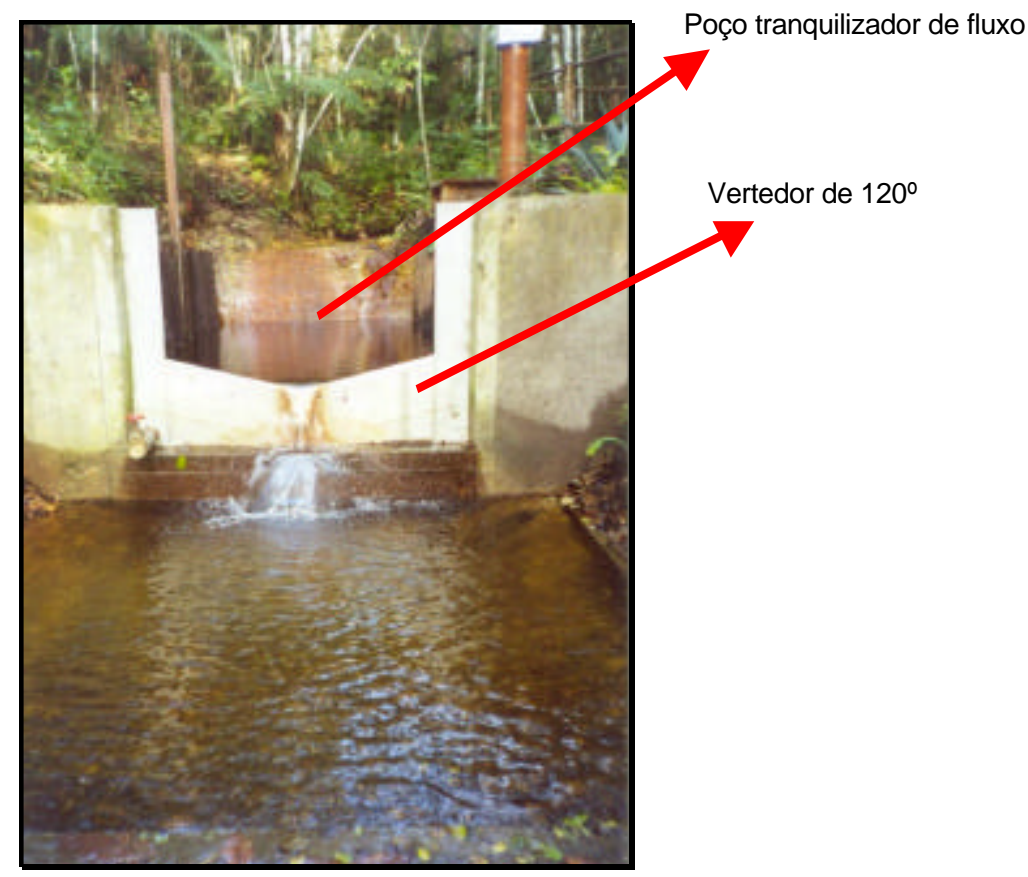

Figura 11 - Visão àmontante do vertedor instalado na microbacia $\mathrm{E}$

A equação de calibragem estabelecida para calcular a vazão em função da leitura da cota do vertedor é a mesma para ambos os vertedores instalados (Fórmula 7). 


$$
Q d=e^{-0,0548(L N ~ h) ~ 3-0,4450(L N ~ h) 2+1,4574(L N ~ h)+0,9955}
$$

$R^{2}=0,9999$

Onde,

$\mathrm{Qd}=$ vazão vertedor desassoreado $\left(\mathrm{m}^{3} / \mathrm{s}\right)$

$\mathrm{H}=$ cota de montante $(\mathrm{m})$

O dimensionamento dos vertedores prevê também situações em que estes funcionem assoreados. Quando isso ocorre, as vazões aumentam cerca de $5 \% \mathrm{em}$ cotas médias e altas. A equação acima foi determinada considerando-se escoamento livre a jus ante.

Nas situações de escoamento com afogamento, essas vazões devem ser multiplicadas por um coeficiente f segundo mostra o Quadro 4.

\begin{tabular}{|l|c|c|c|c|c|}
\hline \multirow{2}{*}{ Situação } & \multicolumn{5}{|c|}{ Submergência S (\%) } \\
\cline { 2 - 6 } & 60 & 70 & 80 & 90 & 95 \\
\hline Desafogado & 0,95 & 0,93 & 0,88 & 0,75 & 0,60 \\
\hline Atogado & 0,90 & 0,84 & 0,75 & 0,60 & ----- \\
\hline
\end{tabular}

Quadro 4 - Coeficiente de correção dos valores de vazão das microbacias em situações de escoamento com afogamento

Os linígrafos digitais registram e armazenam ininterruptamente a data, hora e variação da altura da lâmina da água. Mensalmente os dados armazenados são descarregados em um microcomputador portátil através de um dispositivo de leitura ótica, com programa específico para leitura dos dados, que por sua vez são exportados para um outro computador onde são convertidos para a extensão .xls (planilhas de dados do Microsoft Excel). Cria-se uma tabela no Excel com os dados de cota e tempo referentes a cada mês e, a partir das equações de vazão dos vertedores, obtém-se os dados diários de vazão em m³/s. 


\subsubsection{Medição da precipitação}

A determinação da precipitação das microbacias foi obtida a partir dos dados coletados na estação meteorológica, onde também são registrados os dados de temperatura e umidade relativa do ar. A estação é equipada com os seguintes equipamentos (Figura 12): 1 pluviógrafo digital, um pluviômetro, um medidor de temperatura e umidade relativa do ar e um coletor de alíquotas de água das chuvas.

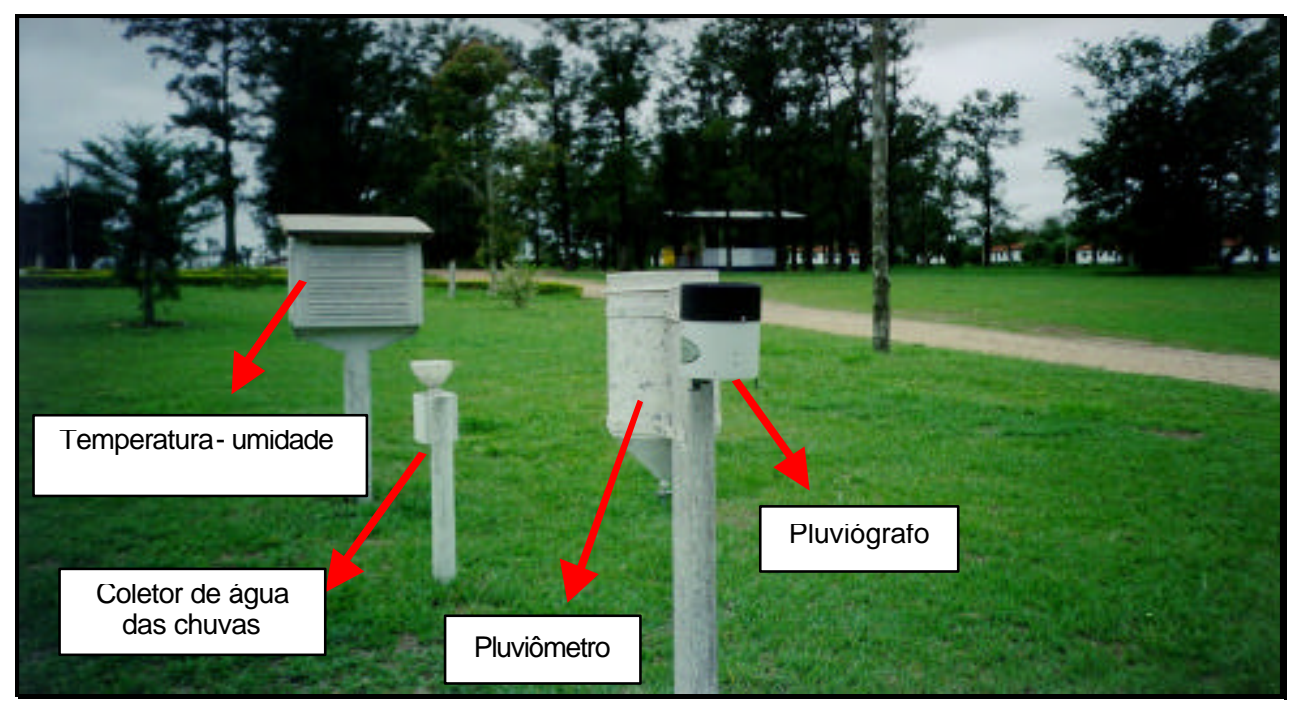

Figura 12 - Estação meteorológica instalada na área experimental da Fazenda Santa Terezinha

A definição do ano hídrico foi realizada através da análise de regressão linear simples entre os dados de precipitação e vazão ao longo de um ano. Estes dados médios mensais são confrontados até obter o melhor coeficiente de correlação. Normalmente o ano hídrico tem início no final da estação seca e início da estação chuvosa, quando a variação do armazenamento da água no solo tende a zero.

\subsubsection{Balanço hídrico}

Através da análise comparativa entre as microbacias e dos dados de precipitação e vazão avaliados no período monitorado para efeito do estudo, buscou-se fechar o balanço hídrico local e regional e quantificar as perdas médias por evapotranspiração. 


\subsection{Comparação das características do deflúvio das microbacias}

Os estudos comparativos das características do deflúvio das microbacias foram desenvolvidos através da análise das curvas de duração de fluxo do deflúvio diário, do escoamento direto e do pico de vazão, segundo metodologia adaptada de Arcova (1996).

\subsection{Qualidade da água: monitoramento dos parâmetros físico-químicos}

Para efeito da pesquisa, a avaliação da qualidade da água foi baseada na análise da variação sazonal dos parâmetros físico-químicos buscando identificar tendências no comportamento desses elementos na água do deflúvio das microbacias monitoradas.

As amostras de água do deflúvio foram coletadas de forma manual nos vertedores. Inicialmente, a cada semana, a fim de verificar se as intervenções provenientes da construção da estrutura física não mais afetariam o resultado das análises. Posteriormente, as coletas passaram a ser quinzenais.

Após a coleta, as amostras de água eram transferidas para garrafas, onde ficavam armazenadas em geladeira até o transporte para o laboratório.

As análises físico-químicas da água foram realizadas no Laboratório de Ecologia Aplicada do Departamento de Ciências Florestais da ESALQ/USP para as seguintes variáveis: turbidez, cor, condutividade, sedimentos, $\mathrm{pH}$, nitrogênio nitrato $(\mathrm{N})$, fósforo $(\mathrm{P})$, potássio $(\mathrm{K})$, cálcio $(\mathrm{Ca})$ e magnésio $(\mathrm{Mg})$.

A turbidez e a cor foram determinadas pelo Método Colorimétrico-DR2000. A condutividade, pelo Condutivimétrico; os sedimentos suspensos por filtração e pesagem e o pH, pelo Método Potenciométrico. Para determinação do nitrato usou-se Brucina e para o Fósforo, Colorimetria. O Potássio, o Cálcio e o Magnésio foram determinados por espectrofometria. 


\subsection{Compactação do solo}

Conforme metodologia adaptada de alguns autores (Oliveira Júnior, 1998; Lima et al., 2000; Fernandes \& Souza, 2001; Seixas, 2002 e Silva et al., 2002) coletaram-se para as duas microbacias, amostras indeformadas de solo com um martelo (MAS) e anéis metálicos de $50,8 \mathrm{~mm}$ de diâmetro por $50,8 \mathrm{~mm}$ de altura. Para cada parcela instalada na microbacia $E$ obteve-se vinte (20) amostras para densidade, sendo dez (10) na fileira de plantio e outras dez na rua, sendo cinco 5 amostras na primeira camada de 5 a $10 \mathrm{~cm}$ de profundidade e outras cinco na segunda camada de 12,5 a $17,5 \mathrm{~cm}$ de profundidade.

Os efeitos avaliados para a microbacia $E$ foram os seguintes (Figura 13):

Efeito "A" (na linha de plantio), entre uma árvore e outra;

Efeito "B" (na entrelinha), cerca de 30 a $35 \mathrm{~cm}$ a partir da árvore.

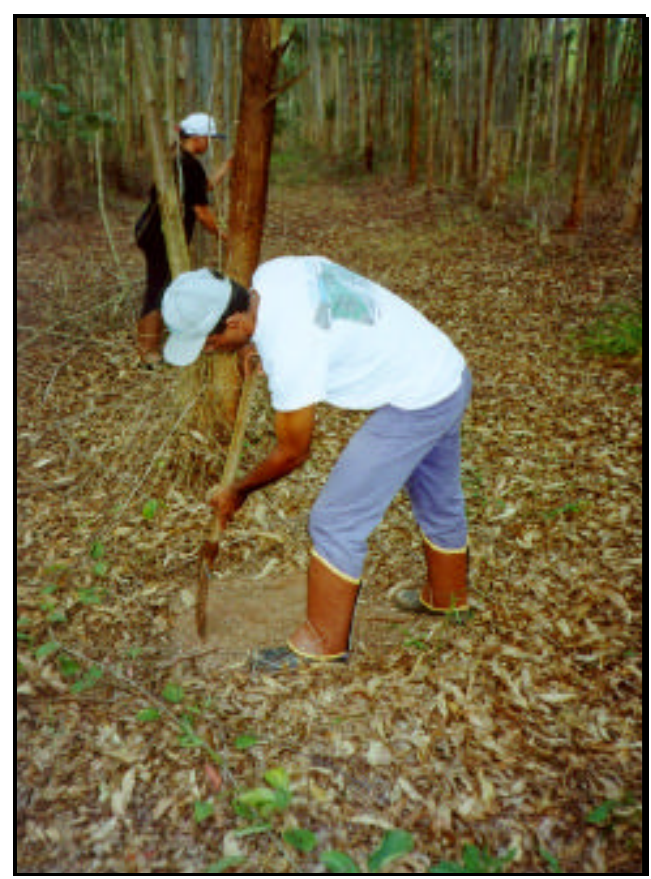

Figura 13 - Amostragem realizada na linha de plantio para avaliar o Efeito "A" da compactação do solo na microbacia $\mathrm{E}$ 
Na microbacia P, para cada parcela instalada, foram obtidas vinte (20) amostras para densidade, sendo dez (10) na trilha do gado e outras dez fora da trilha, sendo cinco (5) amostras na primeira camada de 5 a $10 \mathrm{~cm}$ de profundidade e outras cinco na segunda camada de 12,5 a $17,5 \mathrm{~cm}$ de profundidade

Para a microbacia P avaliou-se (Figura 14):

Efeito "C" (na trilha do gado);

Efeito "D" (fora da trilha).

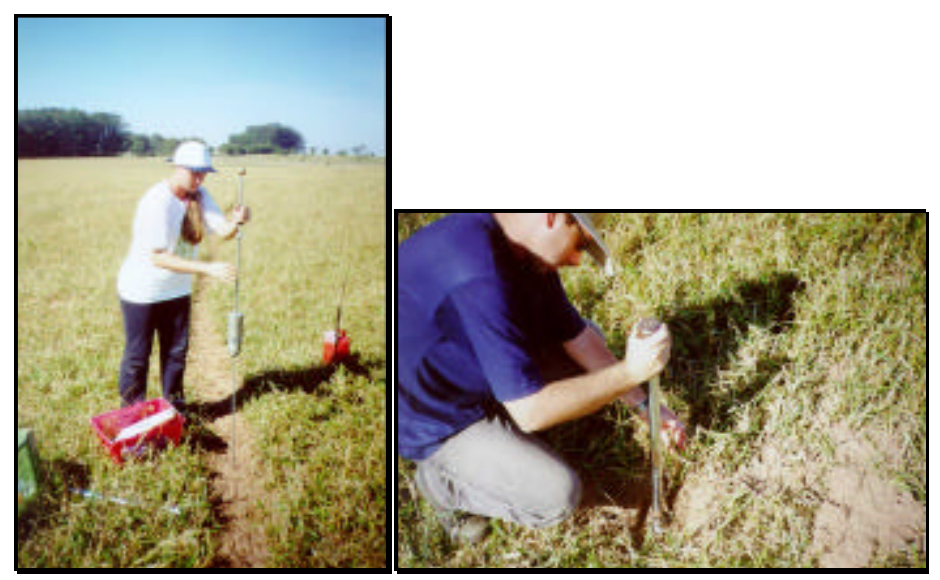

Figura 14 - A primeira fotografia, da esquerda para a direita, refere-se a coleta dos dados de índice de cone na trilha de pisoteio do gado, na microbacia P. A segunda, mostra a coleta das amostras indeformadas de solo para determinação da densidade e teor de umidade

A partir destas amostras determinou-se a densidade de partículas, densidade do solo, teor de água do solo, composição granulométrica e índice de cone, segundo metodologia apresentada pela Embrapa (1979).

\subsubsection{Densidade de partículas ( $\mathbf{p} \mathbf{p})$}

A densidade das partículas é expressa pela relação entre a massa total das partículas do solo e o volume total das mesmas, sem considerar o espaço poroso entre elas. Expressa-se em g/cm³ e, no geral, considera-se seu valor médio de 2,65 (Silva, 1995 e Brady, 1989). 


\subsubsection{Densidade do solo (ps)}

É definida pela relação entre uma massa de solo e o volume total do anel usado para retirar as amostras (Lima et al., 2000). O volume contido no anel metálico usado nas amostragens de campo para o presente trabalho é de $81,54 \mathrm{~cm}^{3}$.

\subsubsection{Teor de água (U)}

É a relação entre a massa de água contida numa amostra, sobre a massa de solo. U é o teor de água do solo estimado e usualmente expresso em porcentagem (Oliveira Júnior, 1999).

Para determinação da massa seca colocaram-se as amostras em estufa a 105ํㄷ $\left(+-2^{\circ} \mathrm{C}\right)$ por $24 \mathrm{~h}$.

\subsection{4 Índice de cone (IC)}

Estimou-se a resistência a penetração do solo pelo índice de cone a partir das leituras obtidas com um penetrômetro de impacto até a profundidade de $50 \mathrm{~cm}$, transformando-se o número de impactos do penetrômetro ao longo do perfil do solo para força por unidade de área (MPa), por meio da Fórmula (8) utilizada por Stolf (1990), como segue:

$$
\text { IC }=0,0981^{*}\left(5,6+6,89^{*} n\right)
$$

Sendo:

$$
\mathrm{n}=\left[\frac{\mathrm{impactos}}{\mathrm{dm}}\right]
$$

Os penetrômetros são constituídos de uma ponteira-padrão e por uma haste, que devem ser introduzidas no solo, com a finalidade de medir o esforço à penetração à medida que esta se desloca ao longo do perfil do solo a uma velocidade constante padronizada.

O índice de cone pode ser entendido como sendo a relação entre a força exercida para introduzir o cone no solo e a sua área da base. 
O desenho experimental foi aleatório, com um total de oito (08) parcelas ( $3 \mathrm{X}$ 20m) para cada microbacia, distribuídas de modo a contemplar as porções alta, média e baixa.

Os valores de índice de cone foram comparados com aqueles obtidos entre árvores, para a microbacia sob eucalipto e fora da trilha de pisoteio, para a microbacia com pasto e entre microbacias. 


\section{RESULTADOS E DISCUSSÃO}

\subsection{Balanço hídrico}

Para realização do balanço hídrico regional, na ausência de uma série histórica de dados de temperatura de Bofete ou da Fazenda Santa Terezinha, foram utilizados dados de precipitação e temperatura referentes a região de Conchas, Anhembi e Itatinga (SP), para o período de 1941 a 1970. Estes dados foram compilados por Sentelhas et al. (1998).

Um resumo dos valores do balanço hídrico regional para estas regiões é apresentado no Quadro 5, para uma capacidade de armazenamento de $100 \mathrm{~mm}$.

\begin{tabular}{|c|c|c|c|cc|c|c|c|}
\hline Estações & & $\begin{array}{c}\mathrm{T} \\
\left({ }^{\circ} \mathrm{C}\right)\end{array}$ & $\begin{array}{c}\mathrm{P} \\
(\mathrm{mm})\end{array}$ & $\begin{array}{c}\text { ETP } \\
(\mathrm{mm})\end{array}$ & $\begin{array}{c}\text { ETR } \\
(\mathrm{mm})\end{array}$ & $\begin{array}{c}\text { ARM } \\
(\mathrm{mm})\end{array}$ & $\begin{array}{c}\text { DEF } \\
(\mathrm{mm})\end{array}$ & $\begin{array}{c}\text { EXC } \\
(\mathrm{mm})\end{array}$ \\
\hline Conchas & Total & 266,2 & 1166,0 & 1091,53 & 1018,7 & 807 & 72,8 & 147,3 \\
& Média & 22,2 & 97,2 & 90,96 & 84,9 & 67,3 & 6,1 & 12,3 \\
\hline Anhembi & Total & 261,5 & 1243,0 & 1055,26 & 1009,9 & 869 & 45,4 & 233,1 \\
& Média & 21,8 & 103,6 & 87,94 & 84,2 & 72,4 & 3,8 & 19,4 \\
\hline Itatinga & Total & 238,5 & 1308,0 & 920,63 & 918,2 & 1148 & 2,4 & 389,8 \\
& Média & 19,9 & 109,0 & 76,72 & 76,5 & 95,7 & 0,2 & 32,5 \\
\hline
\end{tabular}

$\mathrm{T}=$ Temperatura; $\mathrm{P}=$ Precipitação; $\mathrm{ETP}=$ Evapotranspiração Potencial; ETR= Evapotranspiração Real; $A R M=$ Armazenamento; $D E F=$ Deficiência; $E X C=$ Excedente

Fonte: Sentelhas et al. (1998)

De acordo com os dados de temperatura e precipitação utilizados, foi observada deficiência hídrica variando de 72,8 mm a 2,4 mm. Nos meses de maio, junho e julho e no período de setembro a fevereiro ocorre, no geral, reposição de água no solo. Nos 
meses de janeiro, fevereiro, março, junho, outubro, novembro e dezembro ocorrem excedentes de água (variando entre 147,3 a 389,8 mm), sujeitos àpercolação.

Há que se considerar que a ocorrência de déficit hídrico na região, embora seja pequena, associada ao solo areia quartzosa (ou neossolos quartzarênicos, pelos novos critérios de classificação brasileira de solos. EMBRAPA, 19997) de baixa retenção de água, aponta para a necessidade de implementação de técnicas de manejo que possibilitem potencializar a capacidade de armazenamento de água no solo, como um aspecto importante a ser considerado durante o planejamento de uso das microbacias.

Estes valores dos balanços hídricos regionais, quando comparados aos resultados observados no balanço de massa para as microbacias experimentais apontam para valores um pouco elevados.

De fato, os dados coletados nas estações linimétricas para o período experimental apresentaram falhas decorrentes de erro na leitura dos linígrafos, principalmente em eventos de precipitação de intensidade maior. Como forma de compensar os dados perdidos procedeu-se a identificação desses períodos gerando uma média compensada para o período que apresentou falhas.

A forma de registro dos dados pluviométricos também contribuiu para atingir estes valores, uma vez que o pluviógrafo entrou em qeração somente a partir de agosto de 2001. Antes, a leitura era feita manualmente em um pluviômetro do tipo "Ville de Paris".

Em decorrência disto, o cálculo do balanço hídrico das microbacias ou balanço de massa sofreu prejuízos podendo estar superestimado. No entanto, em termos de padrão de comportamento esperado para as microbacias e respectivas coberturas vegetais, o balanço segue os padrões observados na literatura, recentemente apresentados por Cossalter \& Pye-Smith (2003).

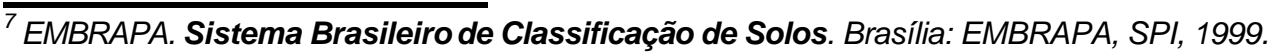


Ressalvados estes aspectos, a Tabela 6 apresenta o balanço de massa efetuado para as microbacias.

Tabela 6. Balanço de massa para a verificação das perdas médias por evapotranspiração nas microbacias monitoradas no período de nov/00 a out/02

\begin{tabular}{lccccc}
\hline Microbacia & $\begin{array}{c}\text { Area da bacia } \\
\text { (há) }\end{array}$ & Ano & $\begin{array}{c}\text { P Total } \\
(\mathrm{mm})\end{array}$ & $\begin{array}{c}\text { Q Total } \\
(\mathrm{mm})\end{array}$ & $\mathrm{P}-\mathrm{Q}$ \\
\hline Eucalipto & 50,23 & Nov/00 a out/01 & 1893,80 & 148,76 & 1745,04 \\
& & Nov/01 a out/02 & 1407,90 & 125,62 & 1282,28 \\
\multicolumn{1}{c}{ média } & & Nov/01 a out/02 & $\mathbf{1 6 5 0 , 8 5}$ & $\mathbf{1 3 7 , 1 9}$ & $\mathbf{1 5 1 3 , 6 6}$ \\
Pasto & \multirow{2}{*}{60,8} & Nov/00 a out/01 & 1893,80 & 383,35 & 1510,45 \\
& & Nov/01 a out/02 & 1407,90 & 365,67 & 1042,23 \\
\multicolumn{1}{c}{ média } & & Nov/01 a out/02 & $\mathbf{1 6 5 0 , 8 5}$ & $\mathbf{3 7 4 , 5 1}$ & $\mathbf{1 2 7 6 , 3 4}$ \\
\hline
\end{tabular}

As elevadas precipitações registradas, principalmente para o ano hídrico de nov/00 a out/01, podem estar representado anos atípicos, quando observada a série histórica de 20 anos de dados de precipitação da Fazenda Santa Terezinha (Apêndice 1.1).

As Figuras 15 e 16 ilustram, simplificadamente, através do balanço de massa, as entradas e saídas de água no sistema para os dois anos de monitoramento.

Considerando que, em ambas as microbacias, a entrada total de água via precipitação somou 1650, $85 \mathrm{~mm}$, observa-se que, para a microbacia E 91,27 \% saiu do sistema via evapotranspiração e 8,3\%, via deflúvio. 


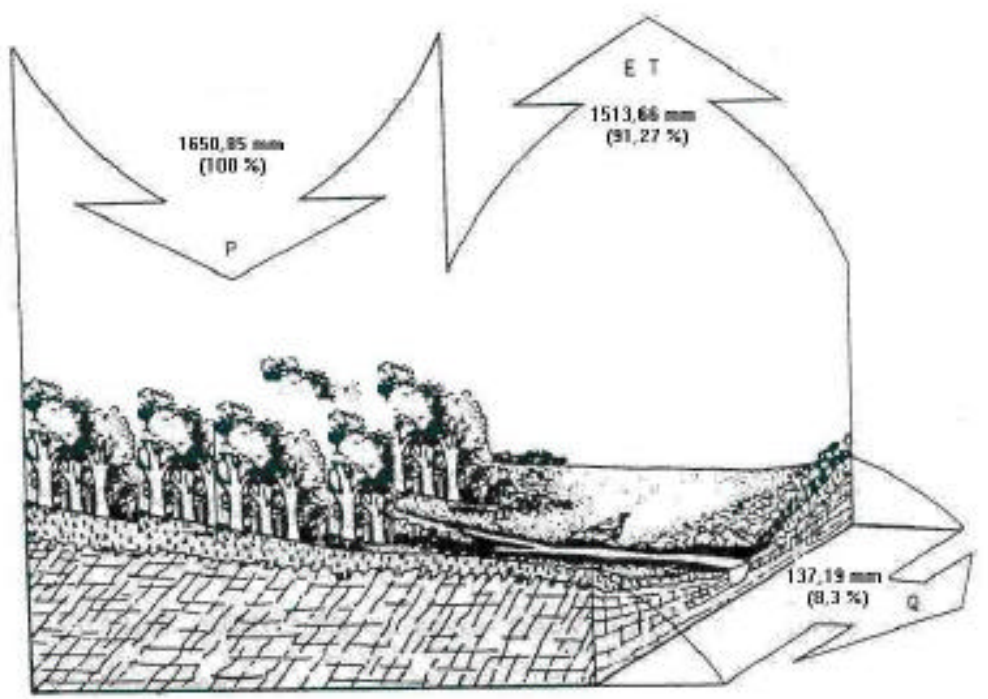

Figura 15 - Representação esquemática do balanço de massa efetuado para a microbacia $E$, sendo: $P$ (entrada de água no sistema via precipitação); ET (saída via evapotranspiração) e Q (deflúvio)

Fonte: Figura adaptada de Ranzini (1990)

Para a microbacia $\mathrm{P}$, verificou-se que 77,3 \% da precipitação evapotranspirou-se. A relação vazão/precipitação é de $22,7 \%$.

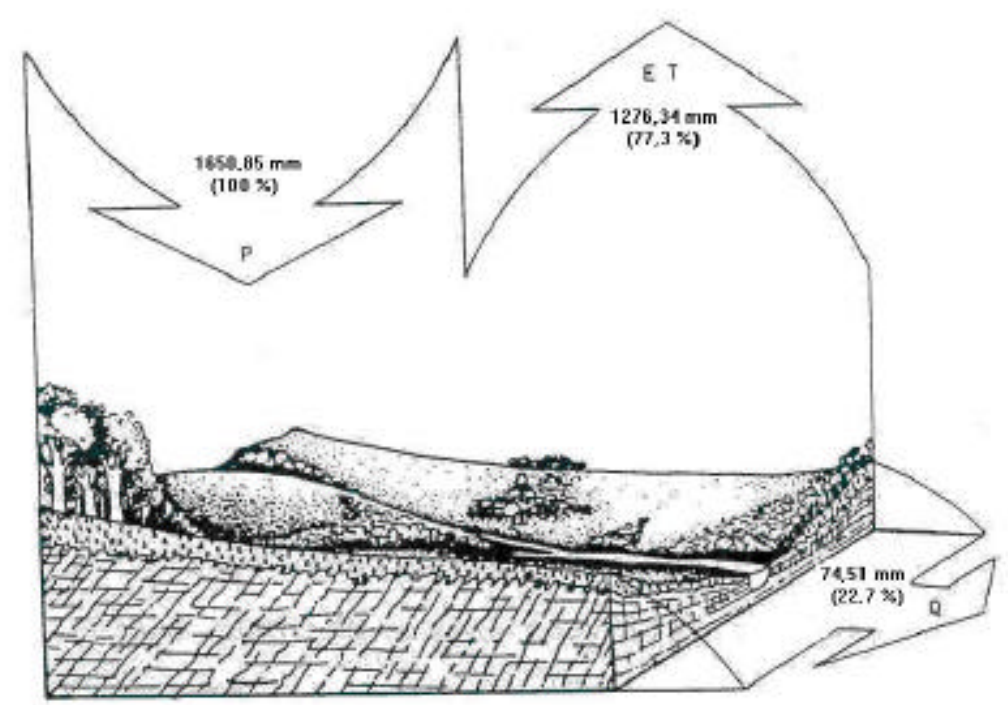

Figura 16 - Representação esquemática do balanço de massa efetuado para a microbacia $P$, sendo: $P$ (entrada de água no sistema via precipitação); ET (saída via evapotranspiração) e Q (deflúvio) 
A idade do povoamento florestal pode ser uma dos fatores que contribuem para tais resultados, mas estudos têm verificado uma tendência no aumento do deflúvio após o corte raso da floresta.

Vital \& Lima (1996) ao estudarem o balanço hídrico em duas microbacias adjacentes reflorestadas com Eucalyptus saligna Smith, localizadas no Vale do Paraíba (SP), observaram valores de evapotranspiração de $1185,9 \mathrm{~mm}$ para a microbacia A e $1128,9 \mathrm{~mm}$ para a microbacia $B$. Observou-se também uma tendência na diminuição do deflúvio com o crescimento do povoamento florestal, assim como o aumento do deflúvio da microbacia A no primeiro ano após o corte raso da plantação.

Comportamento semelhante também foi observado por Câmara (1999) que verificou, durante o primeiro ano hídrico após o corte raso do eucalipto, um aumento no deflúvio anual de $94 \mathrm{~mm}$ em relação àmédia dos seis anos anteriores ao corte. Este aumento correspondeu a uma alteração de 1,0 \% na correlação precipitação/deflúvio.

\subsection{Características hidrológicas}

Foram selecionadas seis (06) estações pluviométricas monitoradas pelo Departamento de Águas e Energia Elétrica do estado de São Paulo, apresentadas no Quadro 6, para verificação da consistência dos dados de precipitação registrados na área experimental.

\begin{tabular}{|c|c|c|c|c|c|}
\hline Estação & Localidade & Bacia & Latitude & Longitude & \begin{tabular}{|c}
$\begin{array}{c}\text { Altitude } \\
(\mathrm{m})\end{array}$ \\
\end{tabular} \\
\hline E5-073 & Itatinga & Novo & $23^{\circ}=66^{\prime}$ & $48^{\circ} 37^{\prime}$ & 870 \\
\hline D5-037 & Anhembi & Tietê médio/inferior & $22^{\circ} 47^{\prime}$ & $48^{\circ}=08^{\prime}$ & 480 \\
\hline D5-044 & Faz. Barreiro Rico & Piracicaba & $22^{\circ} 41^{\prime}$ & $48^{\circ} 07^{\prime}$ & 560 \\
\hline D5-083 & Pirambóia & Peixe & $22^{\circ} 56^{\prime}$ & $48^{\circ} 10^{\prime}$ & 490 \\
\hline E5-016 & Bofete & Peixe & $23^{\circ} 06^{\prime}$ & $48^{\circ} 16^{\prime}$ & 580 \\
\hline E5-001 & Conchas & Conchas & $23^{\circ} 00^{\prime}$ & $48^{\circ} 01^{\prime}$ & 500 \\
\hline E5-064 & Faz. Sta Terezinha & Peixe & $23^{\circ} 04^{\prime}$ & $48^{\circ} 11^{\prime}$ & 580 \\
\hline
\end{tabular}

Quadro 6 - Localização das estações meteorológicas utilizadas para verificar a consistência dos dados das microbacias estudadas 
As médias anuais dessas estações foram confrontadas com a precipitação anual acumulada coletada para as microbacias.

Algumas das estações pluviométricas apresentaram falhas em seus registros devido àausência do observador ou por defeitos no aparelho. Frente ànecessidade de se trabalhar com séries contínuas, essas falhas foram preenchidas através da Equação (10) apresentada por Villela \& Mattos (1975). Segundo os autores, o método utilizado para se fazer esta estimativa tem como base os registros de três estações localizadas o mais próximo possível da estação que apresenta falha nos dados de precipitação.

Designando-se por $\mathbf{x}$ a estação que apresentou falha e por $A, B$, e $C$ as estações vizinhas, pôde-se determinar a precipitação $\mathbf{P x}$ da estação $\mathbf{x}$ pela média ponderada do registro das três estações vizinhas, onde os pesos são as razões entre as precipitações normais anuais e $N$, é a precipitação normal anual.

$$
P x=13\left(\frac{N x}{N A} P A+\frac{N x}{N B} P B+\frac{N x P C}{N C}\right)
$$

A análise de duplas massas permite verificar a homogeneidade dos dados, isto é, se houve alguma anormalidade na estação pluviométrica, tais como mudança de local ou das condições do aparelho ou modificação no método de observação.

De acordo com Villela \& Mattos (1975) esse método consiste em construir-se uma curva dupla acumulativa, na qual são relacionados os totais anuais acumulados de um determinado posto e a média acumulada dos totais anuais de todos os postos da região, considerada homogênea, sob o ponto de vista meteorológico.

Como mostra a Figura 17, a curva obtida não apresentou mudança na declividade, significando que não houve anormalidades no período observado.

A análise de hidrogramas buscando caracterizar períodos sazonais distintos também sofreu prejuízos em função do não registro de alguns picos de vazão com intensidades maiores. Outro fator que limitou a caracterização de uma quantidade maior de eventos foi o início do registro automático da precipitação somente a partir do mês de agosto de 2001, o que não permite o acompanhamento da distribuição e duração da chuva no tempo. 


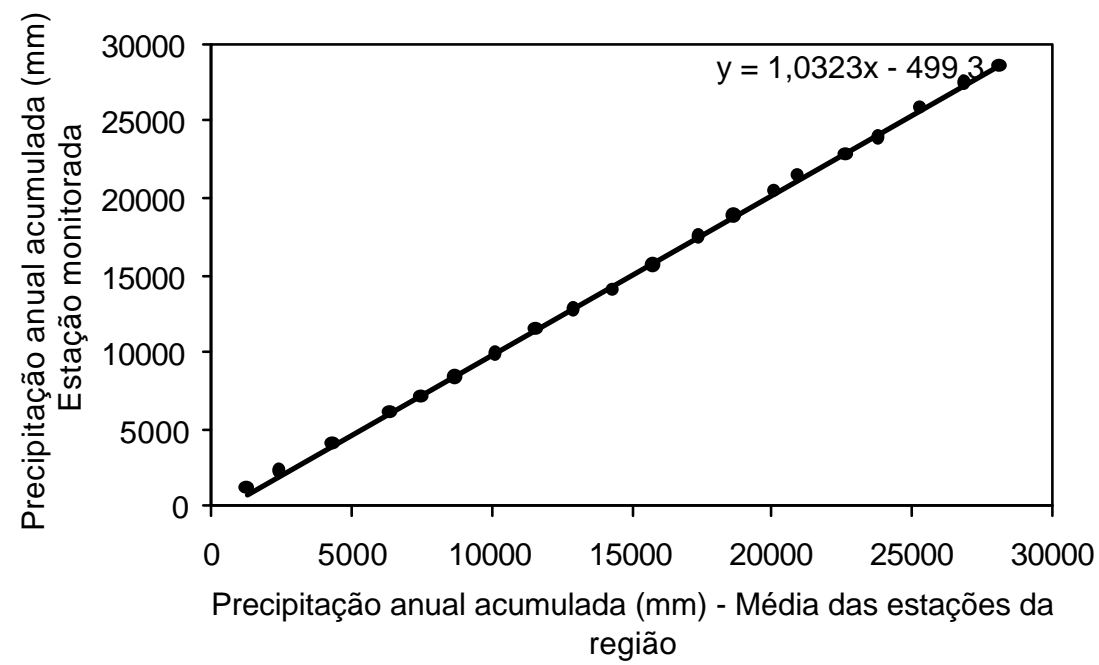

Figura 17 - Verificação da homogeneidade dos dados de precipitação coletados na estação meteorológica instalada na área do experimento

Os eventos hidrológicos selecionados, na medida em que a qualidade do registro dos dados permitiu, são representativos da resposta das microbacias æ̀ precipitações (Apêndice1.2) e da sua capacidade em armazenar água no ecossistema.

As figuras a seguir ilustram, cronologicamente, os eventos selecionados para análise dos hidrogramas, especificados na Tabela 7 e Apêndice 1.3. Para complementar a análise, a Tabela 8 discrimina os respectivos eventos de precipitação.

Tabela 7. Discriminação dos componentes dos hidrogramas analisados para o período experimental

\begin{tabular}{ccccccccc}
\hline \multirow{2}{*}{ Bacia } & Início Ed & Pidrograma & Término Ed & $\begin{array}{c}\text { Duração } \\
\text { Ed }(\mathrm{min})\end{array}$ & $\begin{array}{c}\mathrm{P} \\
(\mathrm{mm})\end{array}$ & $\begin{array}{c}\text { Q } \\
(\mathrm{mm})\end{array}$ & $\begin{array}{c}\text { Ed } \\
(\mathrm{mm})\end{array}$ & $\begin{array}{c}\text { Eb } \\
(\mathrm{mm})\end{array}$ \\
\hline ME & $28 / 11 / 01-23: 15$ & $29 / 11-0: 15$ & $29 / 11 / 01-10: 15$ & 665 & 41,15 & 4,64 & 0,52 & 4,12 \\
MP & $28 / 11 / 01-23: 05$ & $28 / 11-23: 20$ & $29 / 11 / 01-10: 15$ & 675 & 41,15 & 14,26 & 0,71 & 13,55 \\
ME & $07 / 04 / 02-18: 25$ & $07 / 04-19: 00$ & $08 / 04 / 02-1: 25$ & 465 & 10,16 & 0,74 & 0,27 & 0,47 \\
MP & $07 / 04 / 02-17: 20$ & $07 / 04-17: 35$ & $07 / 04 / 02-21: 05$ & 480 & 10,16 & 2,21 & 0,4 & 1,81 \\
ME & $20 / 09 / 02-14: 25$ & $29 / 09-20: 40$ & $21 / 09 / 02-8: 45$ & 1.150 & 26,16 & 3,63 & 0,4 & 3,23 \\
MP & $20 / 09 / 02-14: 05$ & $29 / 09-14: 55$ & $21 / 09 / 02-9: 10$ & 1.550 & 26,16 & 136,86 & 8,3 & 128,56 \\
\hline
\end{tabular}


Tabela 8. Caracterização das precipitações referentes aos hidrogramas analisados.

\begin{tabular}{ccc}
\hline Início da precipitação & Término & Tempo (min) \\
\hline $28 / 11 / 0123: 01$ & $29 / 11 / 0108: 59$ & 598 \\
$07 / 04 / 02 ~ 17: 30$ & $07 / 04 / 0219: 04$ & 95 \\
$20 / 9 / 021: 30$ & $21 / 09 / 0202: 48$ & 1518 \\
\hline
\end{tabular}

A chuva de 41,15 mm ocorrida no dia 29/11/01, com duração de 598 minutos gerou, para a microbacia $\mathrm{E}$ (Figura 18) um escoamento direto de $0,52 \mathrm{~mm}$, sendo 0 escoamento base de $4,12 \mathrm{~mm}(1,27 \%)$. Para esse mesmo evento a microbacia $P$ (Figura 19) apresentou um escoamento direto de $0,71 \mathrm{~mm}$ e o base de $13,55 \mathrm{~mm}(1,72$ $\%)$.

Há que se observar, também, que as últimas chuvas foram registradas 11 dias antes deste evento de 28/11/01 e ocorreram entre os dias 13 e 17 de novembro, somando uma precipitação de $66,04 \mathrm{~mm}$.

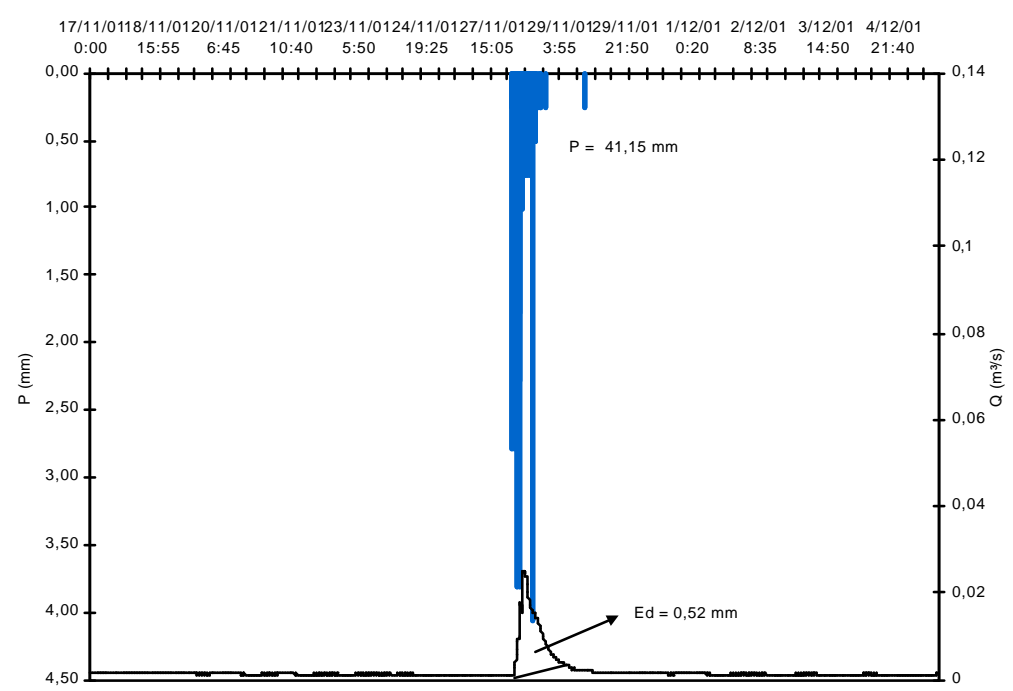

Figura 18 - Hidrograma gerado para a microbacia E em função da chuva ocorrida em 29/11/01

Observa-se, graficamente, que as respostas das microbacia àprecipitação foram bem distintas, indicando maior eficiência da microbacia $E$ na capacidade de infiltração da água no solo. 


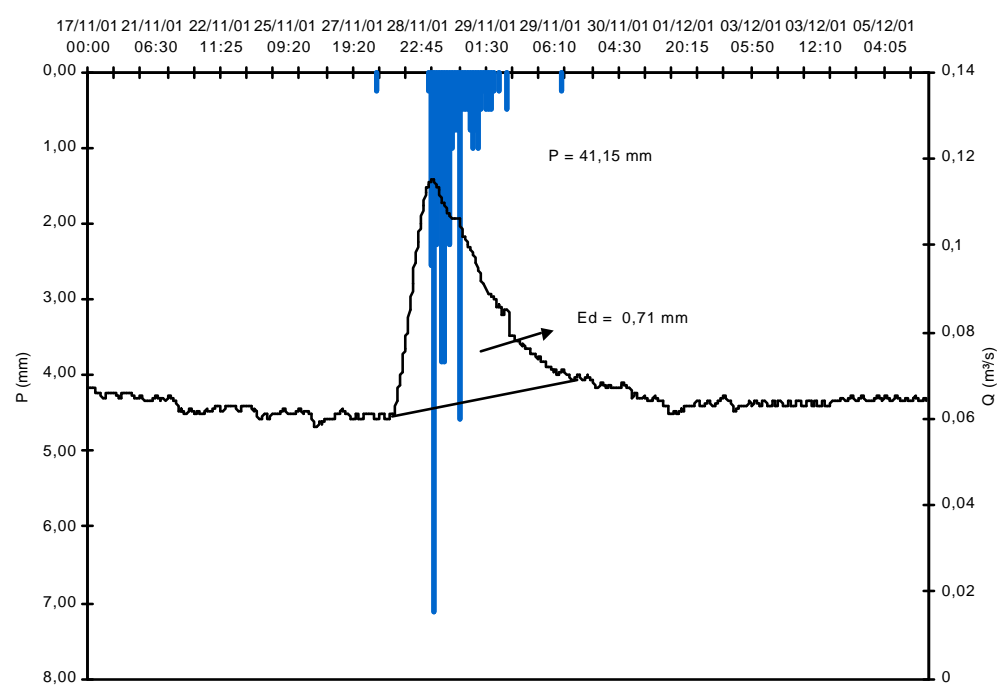

Figura 19 - Hidrograma gerado para a microbacia P em função da chuva ocorrida em 29/11/01

Para uma precipitação ocorrida no dia 07/04/02 de 10,16 mm, o escoamento direto apresentado pela microbacia $E$ (Figura 20 ) foi de $0,27 \mathrm{~mm}$ e para a microbacia $P$ (Figura 21) 0,4 mm sendo, os respectivos escoamentos base, de 0,47 mm e 1,81 $\mathrm{mm}$ $(2,68 \%$ e 3,98 \%). Essa chuva teve a duração de 95 minutos.

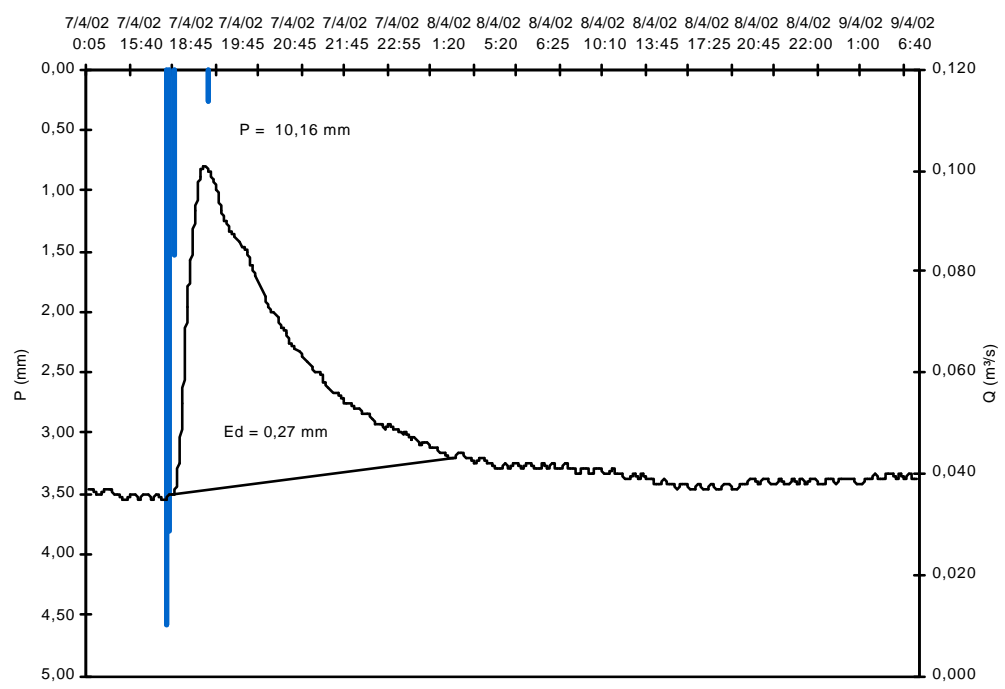

Figura 20 - Hidrograma gerado para a microbacia E em função da chuva ocorrida em 07/04/02 
As últimas precipitações registradas ocorreram 04 dias antes deste evento, somando $1,53 \mathrm{~mm}$.

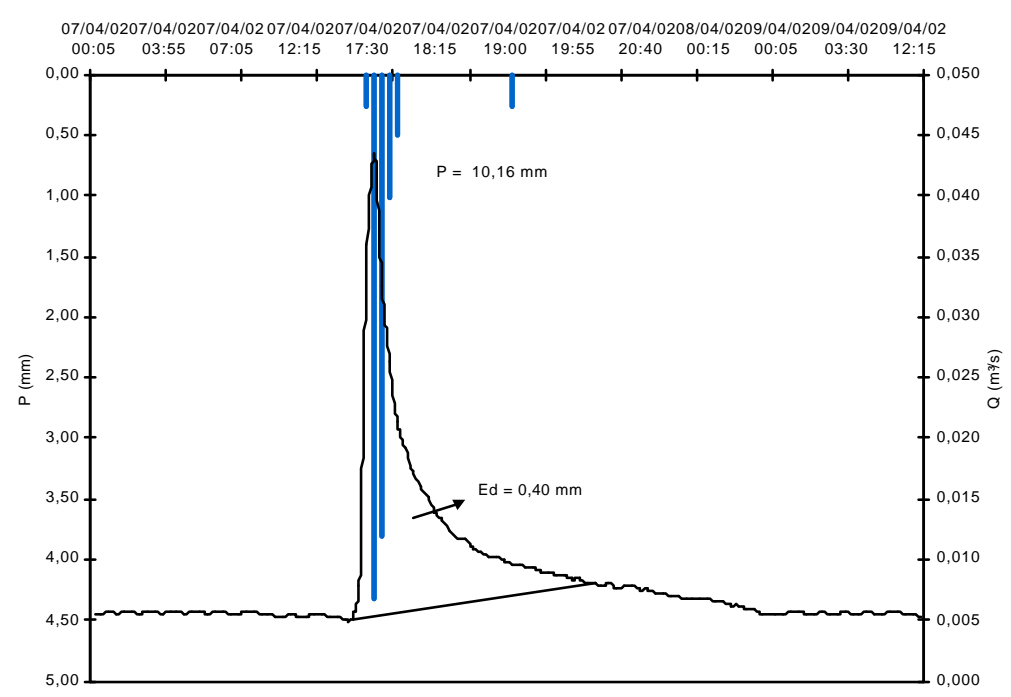

Figura 21 - Hidrograma gerado para a microbacia P em função da chuva ocorrida em 07/04/02

Para 26,6 mm de chuva ocorridos em 20/09/02, a microbacia E (Figura 22) apresentou $0,4 \mathrm{~mm}$ de escoamento direto e 3,23 de escoamento base, expressando $1,53 \%$ na relação precipitação/vazão. A mesma chuva, que durou 1518 minutos, na microbacia P (Figura 23) gerou 8,3 mm de escoamento direto e 128,26 de escoamento base ou seja, 31,74 \% em relação àprecipitação. 


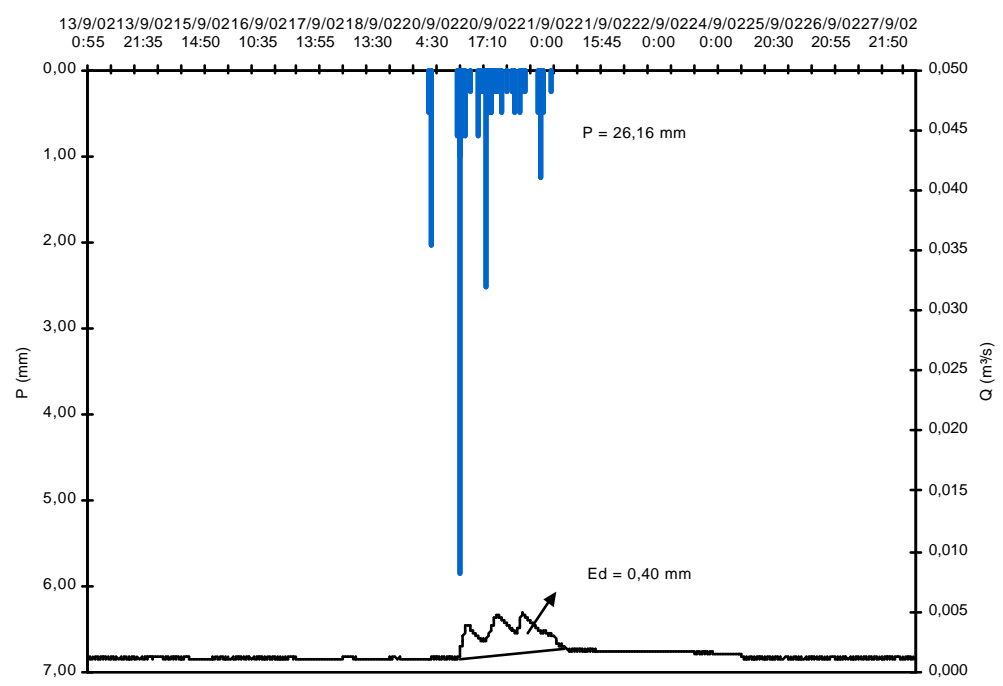

Figura 22 - Hidrograma gerado para a microbacia E em função da chuva ocorrida em 20/09/02

Para se ter uma idéia das condições de umidade antecedente, as precipitações anteriores ao evento ocorreram em 07/09/02 e 14/09/02, somando 20,58 mm.

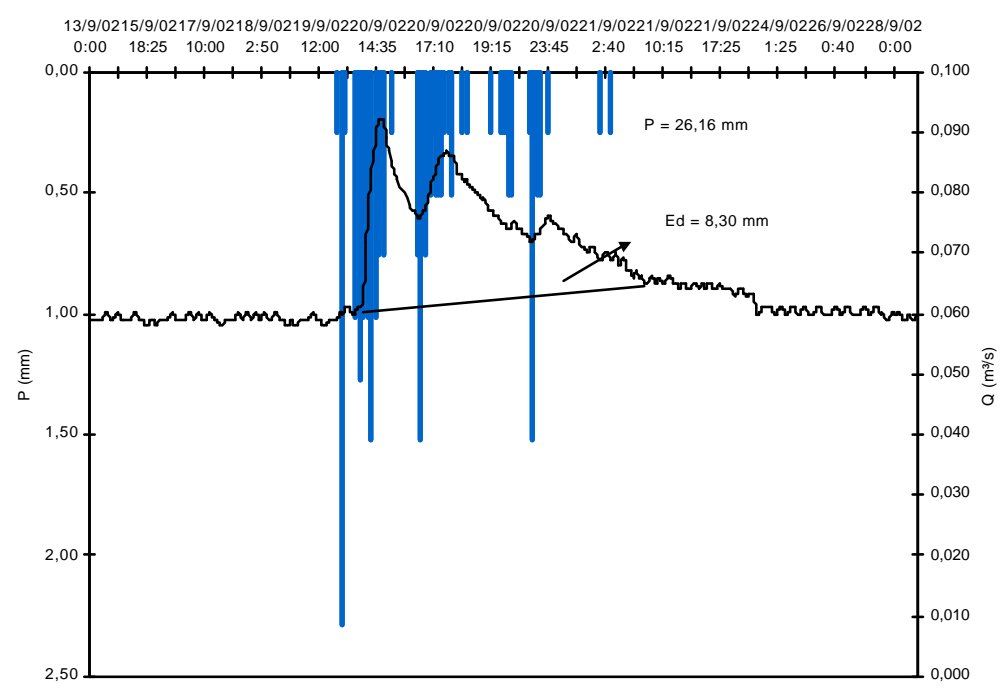

Figura 23 - Hidrograma gerado para a microbacia P em função da chuva ocorrida em 20/09/02

Coletivamente, a análise comparativa destes hidrogramas selecionados mostram maior escoamento direto e maior pico de vazão na microbacia com pastagem. 


\subsection{Qualidade da água}

As concentrações mensais para todos os parâmetros monitorados no deflúvio das microbacias estão apresentadas em anexo (Apêndices 2.1 e 2.2).

\subsubsection{Parâmetros físicos}

Observa-se no Quadro 7 que, em termos de valores médios e variação (mínimo e máximo), a microbacia $\mathrm{E}$ apresentou níveis de concentração de todos os parâmetros avaliados geralmente inferiores aos apresentados pela microbacia $\mathrm{P}$, indicando uma menor perda de nutrientes pelo deflúvio.

\begin{tabular}{|l|c|c|c|c|c|c|}
\hline \multirow{2}{*}{\multicolumn{1}{c|}{ Parâmetros }} & \multicolumn{3}{|c|}{ ME } & \multicolumn{3}{c|}{ MP } \\
\cline { 2 - 7 } & Média & Min. & Max. & Média & Min. & Max. \\
\hline Cor Real (PtCo) & 29 & 17 & 71 & 30 & 4 & 73 \\
Turbidez (FTU) & 42 & 17 & 101 & 318 & 143 & 450 \\
Condutividade (mSc-1) & 0,05 & 0,04 & 0,07 & 0,06 & 0,05 & 0,13 \\
Sedimentos (mg/l) & 135,6 & 21,0 & 563,0 & 4272,6 & 367,7 & 15307,9 \\
PH & 5,7 & 5,5 & 6,0 & 5,9 & 5,5 & 6,2 \\
\hline
\end{tabular}

Quadro 7 - Valores médios e variação (mínimo e máximo) da turbidez, cor real, condutividade, sedimentos e $\mathrm{pH}$ no deflúvio das microbacias $\mathrm{E}$ e $\mathrm{P}$

As diferenças de turbidez e sedimentos entre as microbacias foram mais significativas no período das chuvas, embora os níveis de concentração para a microbacia $\mathrm{P}$ tenham permanecido superiores ao longo do período monitorado (Figura 24 e 25). Entre novembro e junho foram registrados os picos de turbidez nas microbacias.

$O$ valor médio de turbidez detectado na microbacia $P$ foi mais que o triplo do registrado na microbacia $\mathrm{E}$. A maior proteção do solo pela floresta tende a produzir menor taxa de escoamento superficial, comparativamente a microbacia $P$, que apresenta uma cobertura de gramíneas bastante degradada. Consequentemente, os níveis de turbidez da água da microbacia $E$ tendem a ser inferiores, uma vez que o potencial de carreamento de partículas para os cursos d'água é reduzido. Isso também é indicado visualmente (Figura 41). 


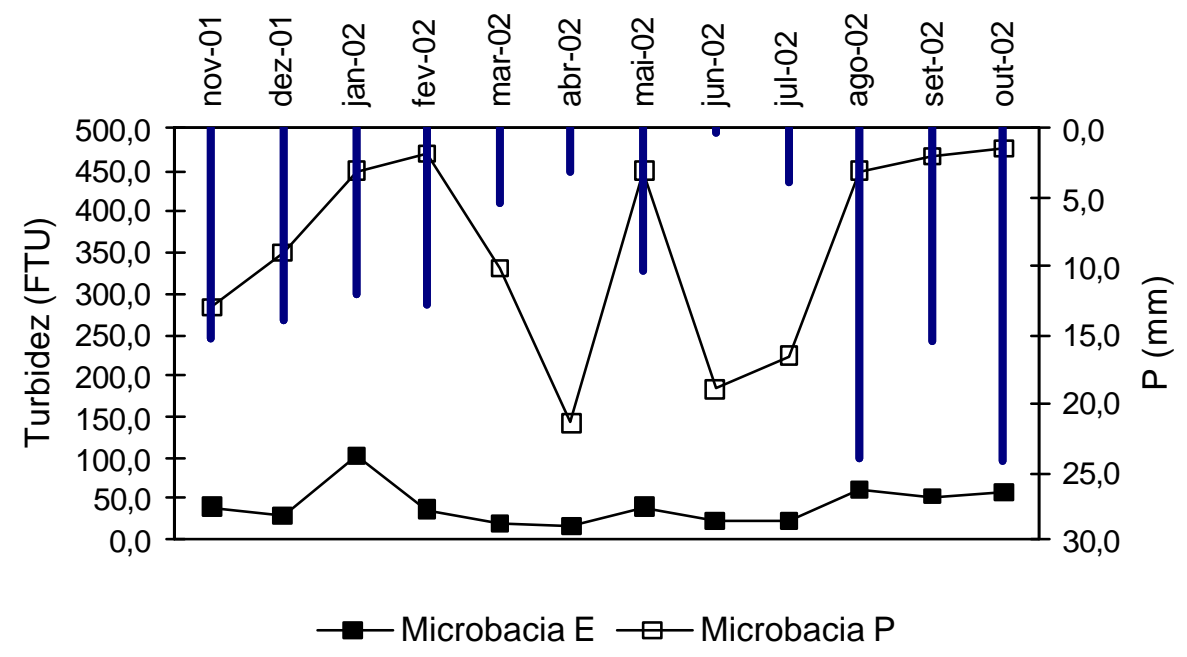

Figura 24 - Precipitação e turbidez média mensal no deflúvio das microbacias

Arcova \& Cicco (1999) ao avaliarem a qualidade da água do deflúvio em quatro microbacias com diferentes usos do solo na região de Cunha (SP), observaram valores médios de turbidez variando de 10,6 a 5,1 (FTU) para microbacias com floresta de Mata Atlântica e valores de 11,6 e 11,8 (FTU) nas microbacias onde predominam atividades de agricultura e pecuária.

A microbacia $\mathrm{P}$ apresentou valores de cor real maiores que a microbacia $\mathrm{P}$. Este parâmetro segue o mesmo padrão apresentado pela turbidez, com os picos de cor real e turbidez ocorrendo nos mesmos meses, isto é de outubro a junho (Figura 16), associados a ocorrência de precipitações. 


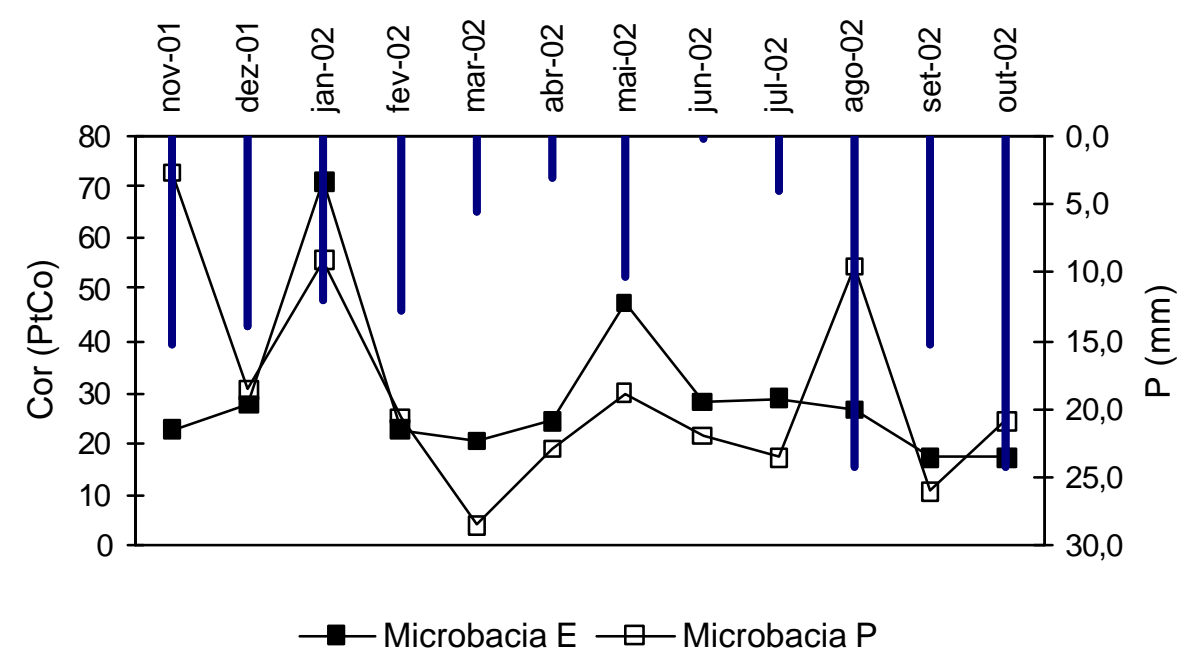

Figura 25 - Valores médios mensais da cor real no deflúvio das microbacias

Azevedo et al. (1995) ao analisarem as características químicas e físicas do deflúvio de microbacias hidrográficas cobertas com pastagem e Eucalyptus grandis, localizadas no município de Teixeira de Freitas (BA), observaram, para a cor real da água, valores de $183 \mathrm{mg} \mathrm{PtCo//} \mathrm{referentes} \mathrm{ao} \mathrm{primeiro} \mathrm{caso} \mathrm{e} 39 \mathrm{mg} \mathrm{Pt} / \mathrm{l}$, para o caso da microbacia com eucalipto.

Rodríguez Anido (2002) ao monitorar uma microbacia experimental recoberta com vegetação natural de Mata Atlântica, verificou valores médios variando de 2 a 8 unidades.

Quanto à condutividade elétrica da água, a microbacia $P$ apresentou valores ligeiramente superiores aos registrados na microbacia E (Figura 26). Mas, no geral, os valores observados não variaram muito para o período monitorado. Os reduzidos valores estão associados aos solos quimicamente fracos.

Arcova \& Cicco (1999) encontraram para o deflúvio de duas microbacias com floresta de Mata Atlântica e outras duas com agricultura e pecuária, os respectivos valores médios de condutividade: 11,6 e 13,3; 12,8 e 16,9 (ì S/cm). 


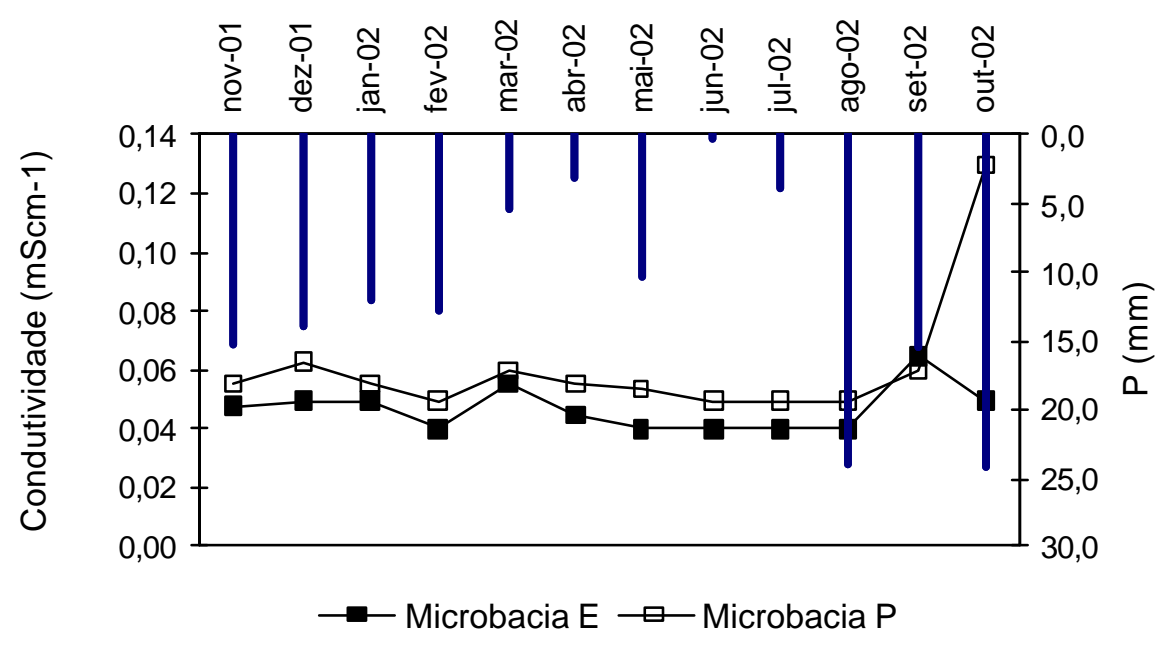

Figura 26 - Valores médios mensais de condutividade no deflúvio das microbacias

Azevedo et al. (1995) observaram valores médios mensais de condutividade da ordem de 65,6 (ì S/cm) no deflúvio de uma microbacia com pastagem. Para uma microbacia com Eucalyptus grandis esses valores corresponderam a 76,5.

As elevadas taxas de concentração de turbidez e sedimentos (Figura 24 e 27) se devem também às condições geológicas e pedológicas do local. Embora, para a microbacia $E$ um outro fator que contribui para elevar o índice de turbidez é a presença de dois carreadores contornando a área de preservação permanente.

No caso da microbacia $P$, os elevados índices observados devem-se, também, a exposição da nascente ao pisoteio do gado favorecendo a desagregação das partículas do solo e àformação de vossorocas. Nesse sentido, as trilhas formadas pelo pisoteio do gado funcionam como direcionamento do fluxo de escoamento superficial escavando ainda mais o solo e agravando o estado das erosões.

Os picos referentes aos elevados valores observados principalmente no deflúvio da microbacia $P$ indicam a participação efetiva do escoamento superficial na geração do deflúvio e no carreamento e aporte de sedimentos que chega ao vertedor. 


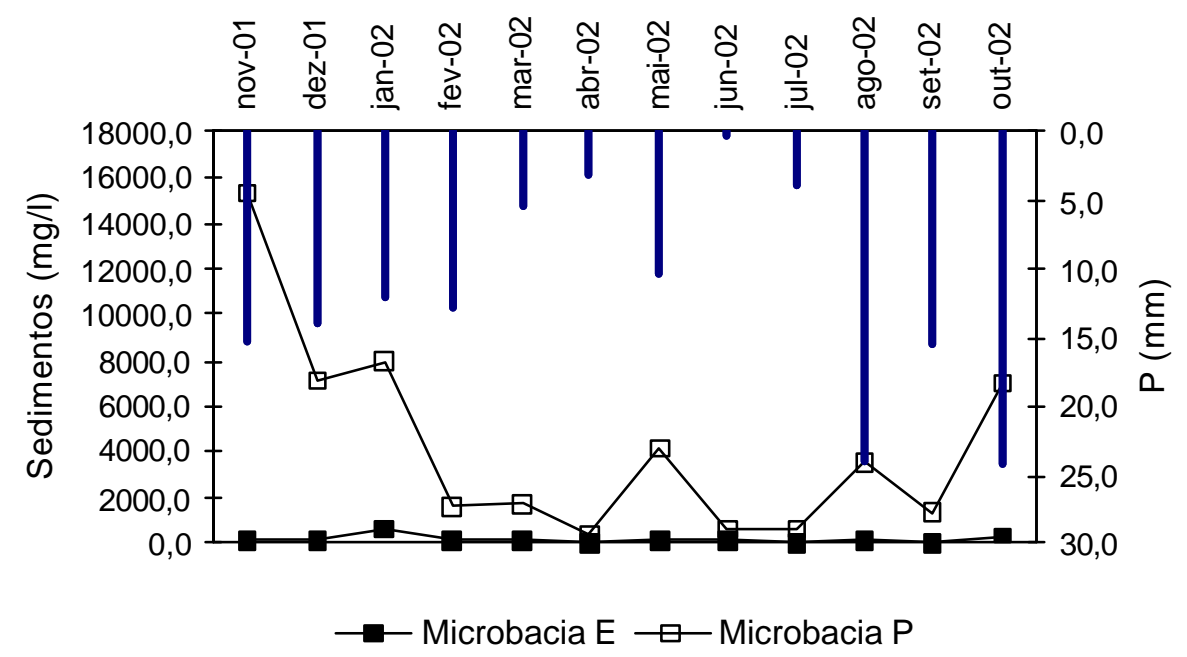

Figura 27 - Valores médios mensais de sedimentos na água das microbacias

A resposta da produção de sedimentos verificada no deflúvio das microbacias e associada aos eventos de precipitação demonstra, assim, a validade dos indicadores visuais identificados para as microbacias.

Como mostra a Figura 28 , os valores de $\mathrm{pH}$ oscilaram mais para a microbacia $\mathrm{P}$, mantendo um comportamento mais constante na microbacia $\mathrm{E}$.

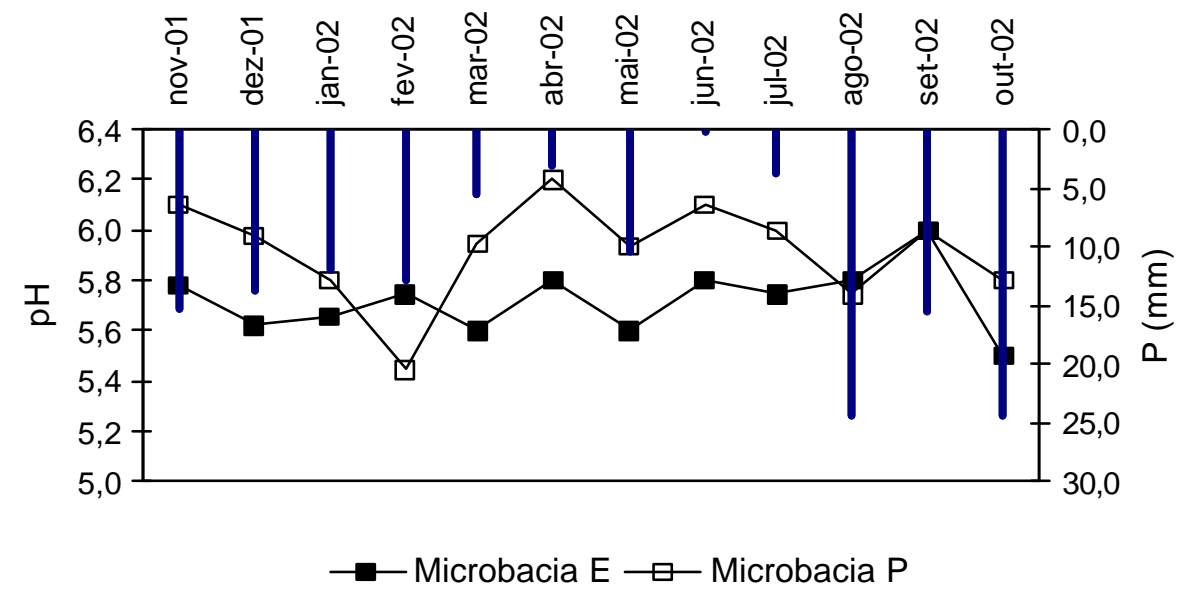

Figura 28 - Valores médios mensais do $\mathrm{pH}$ na água do deflúvio das microbacias 
Valores médios mensais de pH encontrados por Azevedo et al. (1995) no deflúvio de uma microbacia com pastagem foram de 5,73. A microbacia com Eucalyptus grandis apresentou valores de 6,10.

\subsubsection{Parâmetros químicos}

O Quadro 8apresenta, em termos médios e variação (mínimo e máximo), o comportamento das concentrações de nitrogênio nitrato, fósforo, potássio, cálcio e magnésio observados durante o período monitorado.

\begin{tabular}{|l|c|cc|c|c|c|}
\hline \multirow{2}{*}{ Parâmetro } & \multicolumn{3}{|c|}{ ME } & \multicolumn{3}{c|}{ MP } \\
\cline { 2 - 7 } & Média & Min & Máx & Média & Min & Máx \\
\hline Nitrato & 0,8 & 0,3 & 2,6 & 5,5 & 2,3 & 7,5 \\
Fósforo & 0,07 & 0,02 & 0,43 & 0,46 & 0,08 & 2,73 \\
Potássio & 0,6 & 0,3 & 2,0 & 1,9 & 1,0 & 5,7 \\
Cálcio & 0,5 & 0,3 & 1,2 & 1,8 & 1,2 & 6,6 \\
Magnésio & 0,17 & 0,10 & 0,23 & 0,7 & 0,4 & 2,3 \\
\hline
\end{tabular}

Quadro 8 - Valores médios e variação (mínimo e máximo) do nitrato, fósforo, potássio, cálcio e magnésio no deflúvio das microbacias E e $\mathrm{P}$

De um modo geral, observa-se que, semelhantemente aos parâmetros físicos a microbacia $P$ apresentou concentrações mais elevadas em relação àquelas observadas para a microbacia E.

As perdas médias mensais de nutrientes pelo deflúvio, em $\mathrm{kg} / \mathrm{ha}$, são apresentadas nas tabelas a seguir, referentes ao ano hídrico de novembro de 2001 a outubro de 2002 para as duas microbacias monitoradas.

Para a microbacia E (Tabela 9), o nitrogênio apresentou perdas ligeiramente mais elevadas entre os parâmetros avaliados. Para todos os nutrientes, as perdas mais significativas ocorreram nos meses de janeiro, agosto e setembro/02. 
Tabela 9. Perdas médias mensais de nutrientes no deflúvio da microbacia $E$

\begin{tabular}{lcccccc}
\hline Mès & $\begin{array}{c}P \\
(\mathrm{~mm})\end{array}$ & $\begin{array}{c}\text { Nitrato } \\
(\mathrm{Kg} / \mathrm{ha})\end{array}$ & $\begin{array}{c}\text { Fósforo } \\
(\mathrm{Kg} / \mathrm{ha})\end{array}$ & $\begin{array}{c}\text { Potássio } \\
(\mathrm{Kg} / \mathrm{ha})\end{array}$ & $\begin{array}{c}\text { Cálcio } \\
(\mathrm{Kg} / \mathrm{ha})\end{array}$ & $\begin{array}{c}\text { Magnésio } \\
(\mathrm{Kg} / \mathrm{ha})\end{array}$ \\
\hline nov-01 & 15,34 & 0,04 & 0,004 & 0,05 & 0,05 & 0,02 \\
dez-01 & 13,81 & 0,03 & 0,004 & 0,04 & 0,06 & 0,01 \\
jan-02 & 12,01 & 0,07 & 0,005 & 0,04 & 0,13 & 0,02 \\
fev-02 & 12,81 & 0,06 & 0,004 & 0,03 & 0,06 & 0,02 \\
mar-02 & 5,51 & 0,19 & 0,003 & 0,04 & 0,03 & 0,01 \\
abr-02 & 3,05 & 0,02 & 0,002 & 0,02 & 0,03 & 0,01 \\
mai-02 & 10,36 & 0,05 & 0,003 & 0,05 & 0,04 & 0,02 \\
jun-02 & 0,25 & 0,05 & 0,001 & 0,02 & 0,02 & 0,01 \\
jul-02 & 3,88 & 0,05 & 0,002 & 0,02 & 0,02 & 0,01 \\
ago-02 & 24,18 & 0,11 & 0,010 & 0,09 & 0,09 & 0,05 \\
set-02 & 15,41 & 0,04 & 0,023 & 0,11 & 0,03 & 0,01 \\
out-02 & 24,26 & 0,03 & 0,002 & 0,03 & 0,02 & 0,01 \\
Total & 140,87 & 0,74 & 0,06 & 0,54 & 0,58 & 0,19 \\
\hline
\end{tabular}

Na microbacia $P$ as perdas médias mensais de nutrientes pelo deflúvio (Tabela 10) se mostraram, no geral, mais elevadas em relação a microbacia $E$, principalmente nos meses de dezembro/01, janeiro, fevereiro e outubro/02.

Em termos de perdas médias mensais dos nutrientes calculadas para a microbacia P, o nitrato apresentou o maior valor, $19,59 \mathrm{Kg} / \mathrm{ha} / \mathrm{ano}$, sendo o mês de dezembro/01 o que contribuiu com as perdas mais elevadas. 
Tabela 10. Perdas médias mensais de nutrientes no deflúvio da microbacia $P$

\begin{tabular}{lcccccc}
\hline \multicolumn{1}{c}{ Més } & $\begin{array}{c}\mathrm{P} \\
(\mathrm{mm})\end{array}$ & $\begin{array}{c}\text { Nitrato } \\
(\mathrm{Kg} / \mathrm{ha})\end{array}$ & $\begin{array}{c}\text { Fósforo } \\
(\mathrm{Kg} / \mathrm{ha})\end{array}$ & $\begin{array}{c}\text { Potássio } \\
(\mathrm{Kg} / \mathrm{ha})\end{array}$ & $\begin{array}{c}\text { Cálcio } \\
(\mathrm{Kg} / \mathrm{ha})\end{array}$ & $\begin{array}{c}\text { Magnésio } \\
(\mathrm{Kg} / \mathrm{ha})\end{array}$ \\
\hline Nov-01 & 15,34 & 1,25 & 0,04 & 0,75 & 0,31 & 0,13 \\
Dez-01 & 13,81 & 3,46 & 0,25 & 1,28 & 0,80 & 0,37 \\
Jan-02 & 12,01 & 2,44 & 0,24 & 0,57 & 0,51 & 0,18 \\
Fev-02 & 12,81 & 1,36 & 1,09 & 0,92 & 0,72 & 0,22 \\
mar-02 & 5,51 & 1,67 & 0,03 & 0,44 & 0,34 & 0,01 \\
abr-02 & 3,05 & 1,42 & 0,02 & 0,34 & 0,35 & 0,13 \\
mai-02 & 10,36 & 1,80 & 0,13 & 0,39 & 0,38 & 0,15 \\
jun-02 & 0,25 & 1,41 & 0,02 & 0,23 & 0,30 & 0,09 \\
jul-02 & 3,88 & 1,71 & 0,02 & 0,22 & 0,33 & 0,10 \\
ago-02 & 24,18 & 1,32 & 0,16 & 0,30 & 0,31 & 0,13 \\
set-02 & 15,41 & 1,22 & 0,02 & 0,27 & 0,30 & 0,11 \\
out-02 & 24,26 & 0,52 & 0,02 & 1,32 & 1,51 & 0,53 \\
Total & 140,87 & 19,59 & 2,04 & 7,01 & 6,17 & 2,15 \\
\hline
\end{tabular}

Na Figura 29 observam-se as elevadas saídas via deflúvio, notadamente na microbacia $P$. 


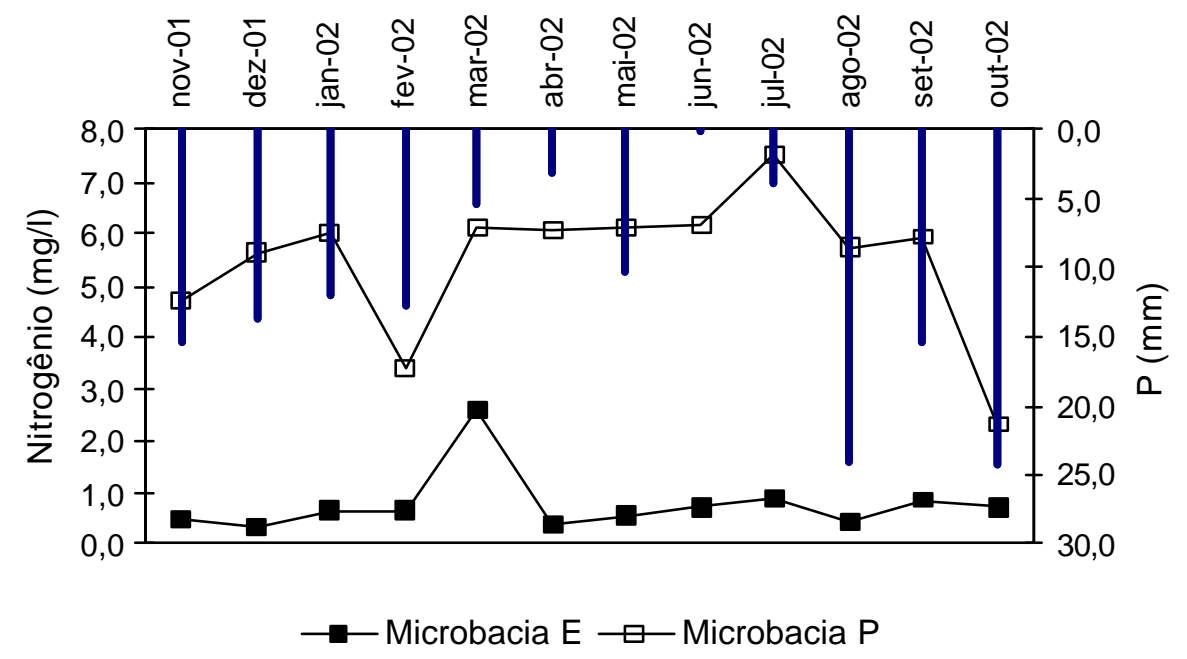

Figura 29 - Valores médios mensais do nitrato (nitrogênio) no deflúvio das microbacias

Para a microbacia E, a perda anual de nitrato correspondeu a 0,74 kg/ha, apresentando um pico de 0,19 kg/ha em março de 2002 .

O fósforo, pela característica natural de estar disponível em baixas concentrações no ambiente e por ser pouco móvel, apresentou as menores perdas observadas em relação aos demais nutrientes para ambas as microbacias (Figura 30). 


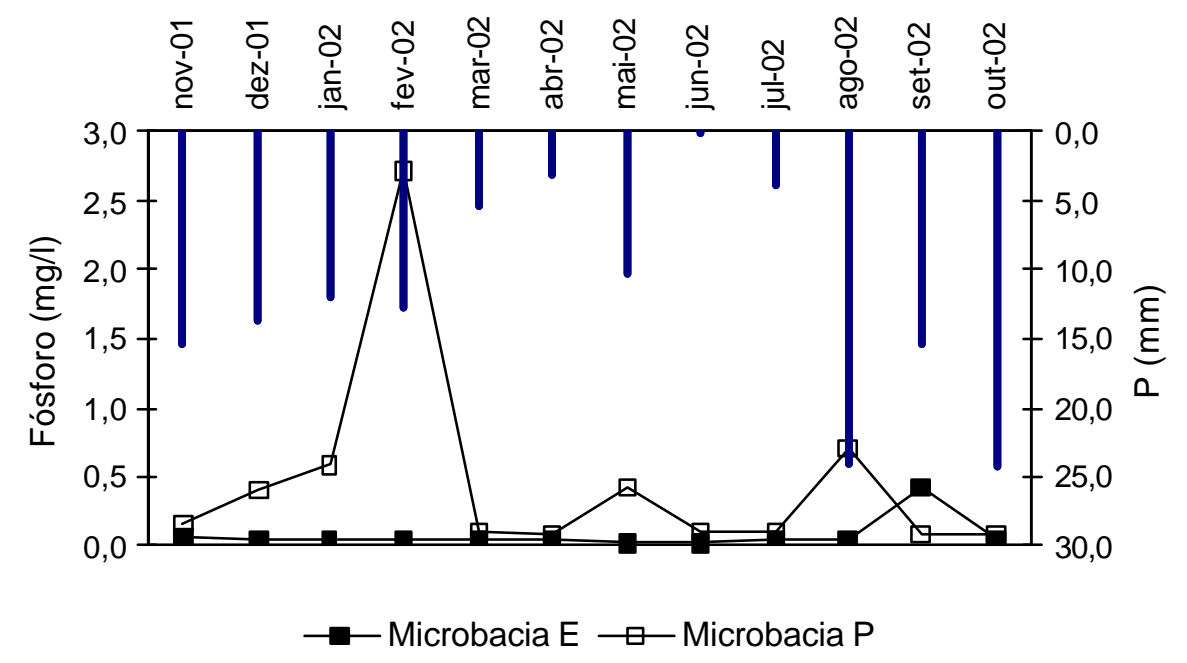

Figura 30 - Valores mensais de fósforo na água das microbacias

Para a microbacia $\mathrm{P}$ as perdas ao longo do ano somaram $2,04 \mathrm{~kg} / \mathrm{ha}$, sendo que no mês de fevereiro/02 observou-se uma considerável perda na ordem de 1,09 kg/ha. Na microbacia $\mathrm{E}$, seu comportamento no deflúvio tendeu a um comportamento mais estável, resultando em $0,06 \mathrm{~kg} / \mathrm{ha}$ perdidos.

Os valores de potássio observados não variaram proporcionalmente aos eventos de precipitação. Para a microbacia E a perda, em $\mathrm{kg} / \mathrm{ha}$, correspondeu a 0,54 , enquanto que na microbacia $P$, o valor observado foi de 7,01 . Nota-se na Figura 31 um pico no mês de outubro/02 de aproximadamente $6,0 \mathrm{mg} / \mathrm{l}$. 


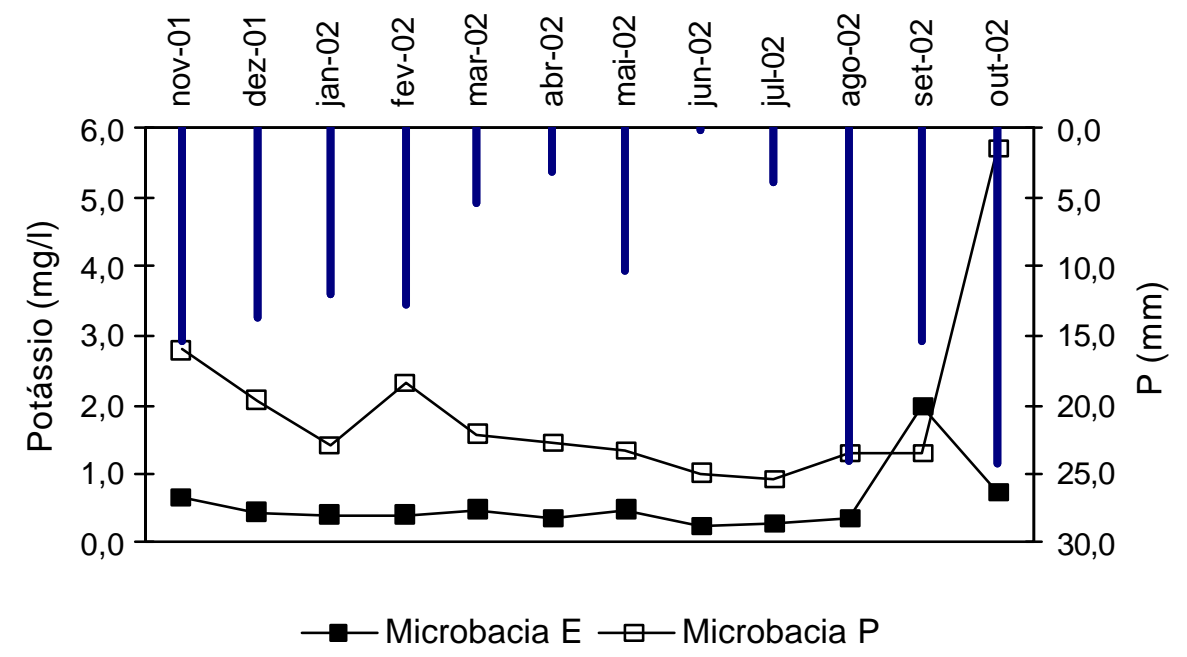

Figura 31 - Valores mensais de potássio na água das microbacias

A variação da concentração média mensal de $\mathrm{K}$ no deflúvio de uma microbacia com Eucalyptus grandis observada por Scardua (1994) oscilou de 0,11 a 0,45 mg/l. Azevedo et al. (1993) monitorando uma microbacia recoberta com Eucalyptus saligna encontrou valores de $0,77 \mathrm{mg} / \mathrm{l}$. Para uma microbacia com pasto, as concentrações foram de $1,59 \mathrm{mg} / \mathrm{l}$.

As concentrações médias mensais de cálcio no deflúvio das microbacias apresentaram um comportamento estável, exceto para os meses de janeiro/02. $\mathrm{Na}$ microbacia $P$ observa-se, também, (Figura 32) uma alteração no mês de outubro/02, para os demais meses sua concentração foi de $2,0 \mathrm{mg} / \mathrm{l}$, com uma perda de $6,17 \mathrm{~kg} / \mathrm{ha}$ no ano monitorado. 


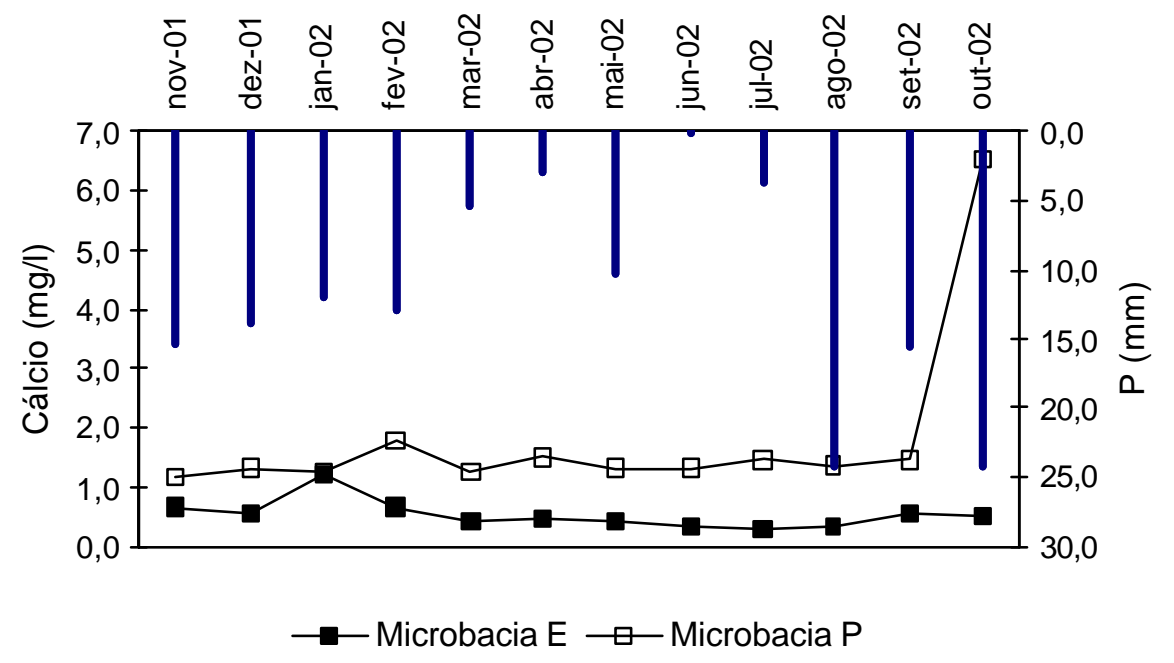

Figura 32 - Valores mensais de cálcio na água das microbacias

A perda anual na microbacia E, para o cálcio, foi de $0,58 \mathrm{~kg} / \mathrm{ha}$.

As concentrações médias mensais observadas no deflúvio da microbacia $E$ variaram de 0,6 a 1,20 mg/l, assemelhando-se aos valores encontrados por Scardua (1994).

Azevedo et al. (1995) obteve valores referentes ao deflúvio de 0,28 mg/l em microbacia com eucalipto e $0,82 \mathrm{mg} / \mathrm{l}$, em microbacia com pasto.

O magnésio também apresentou perdas menores quando comparado aos demais nutrientes observados, sendo $0,19 \mathrm{~kg} / \mathrm{ha}$ para a microbacia $E$ e 2,15 kg/ha, para a microbacia $P$. 


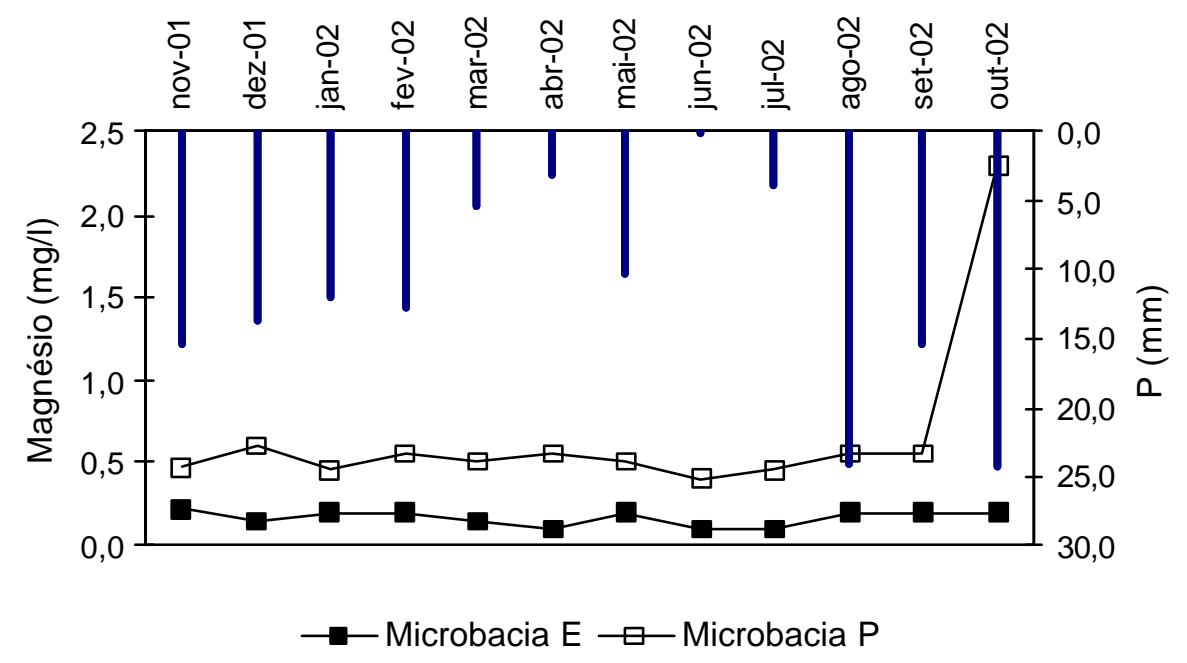

Figura 33 - Valores mensais de magnésio na água das microbacias

A variação do comportamento do magnésio, mostrada na Figura 33, expressa em $\mathrm{mg} /$, foi sensível somente no mês de outubro, saindo de uma concentração média de 0,5 para quase $2,5 \mathrm{mg} / \mathrm{l}$.

Ao caracterizar uma microbacia hidrográfica coberta por rebrota de reflorestamento de Eucalyptus saligna, Scardua (1994) observou valores que oscilaram de 0,36 a $0,60 \mathrm{mg} / \mathrm{l}$ para o deflúvio.

Os valores médios mensais encontrados por Azevedo et al. (1995) corresponderam a $0,87 \mathrm{mg} / \mathrm{l}$ para o deflúvio de uma microbacia com eucalipto e 0,80 , para uma microbacia com pasto.

Em duas microbacias adjacentes, cobertas com Eucalyptus saligna, Vital (1996) observou concentrações médias anuais da densidade de fluxo $\left(\mathrm{kg} \cdot \mathrm{ha}^{-1}\right.$. ano $\left.{ }^{-1}\right)$ de 0,92 no deflúvio da microbacia $A$ e 1,45 no deflúvio da microbacia $B$.

De um modo geral, para todos os nutrientes, verificou-se uma brusca alteração no comportamento da maioria dos parâmetros no mês de outubro/02 para a microbacia $\mathrm{P}$, indicando a ocorrência de alguma perturbação nesse ecossistema. Para a microbacia $E$ as concentrações não sofreram variação. Isso pode dar uma idéia do grau de resiliência dos ecossistemas e do estado da saúde das microbacias. 
Poggiani (1981) cita que a floresta quando em equilíbrio, reduz ao mínimo a saída de nutrientes do ecossistema através da interação solo-vegetação. Desta forma, o solo pode manter o mesmo nível de fertilidade, ou até melhorar suas características ao longo do tempo.

Estas considerações realçam o comportamento verificado para a microbacia $E$ quanto æ̀s perdas médias de nutrientes em ha/ano e ao fluxo dos nutrientes no deflúvio. A maior fertilidade do solo também confirma-se, conforme mostra os resultados das análises fisico-químicas do solo das microbacias na Tabelas 4 e 5.

\subsection{Densidade de partículas ( $\rho p)$, densidade do solo ( $\rho$ s) e teor de umidade (U\%)}

Para a densidade de partículas, índice diretamente vinculado àgranulometria do solo e, consequentemente, não sujeito a sofrer grandes variações, considerou-se o valor médio de $2,65 \mathrm{~g} / \mathrm{cm}^{3}$, conforme recomendado por Silva (1995).

Ressalta-se que o estudo limitou-se àobservação das situações encontradas em ambos os ecossistemas, como efeito do histórico de perturbação, não havendo aplicação de quaisquer tratamentos. A variância dos dados coletados, observada na análise estatística, reflete, portanto as peculiaridades de cada local.

A variabilidade dos dados da microbacia $E$, tanto para densidade do solo, como para compactação, foi maior se comparados aos dados coletados na microbacia P. O que se explica, em parte, conforme detalhado no material e métodos, pela heterogeneidade da idade dos plantios de eucalipto, logo das operações florestais efetuadas e da irregularidade do rastro das máquinas florestais nas entrelinhas de plantio, nem sempre correspondendo aos $35 \mathrm{~cm}$ avaliados a partir da árvore.

Os ecossistemas são considerados, pelas características inerentes a ambos, naturalmente diferenciados em termos de estrutura, cobertura vegetal, heterogeneidade, dentre outros fatores. Por isso buscou-se explorar mais a análise dos dados dentro das microbacias. Detectou-se, assim, diferença estatisticamente significativa nos resultados obtidos entre os locais dos ecossistemas avaliados, sendo: 
na linha de plantio e na entrelinha, para a microbacia $E$ e, na trilha do gado e fora dela, para a microbacia $P$.

Constatou-se, também, uma maior variabilidade para ambos os parâmetros avaliados na microbacia E, se comparados os ecossistemas. Esta diferença do grau de heterogeneidade indica uma maior variância para os dados coletados na microbacia $\mathrm{E}$.

As análises de variância apresentadas nas Tabela 11 e 12, a seguir, referem-se aos valores de densidade do solo observados nos distintos locais, para cada microbacia. Verificou-se diferenças estatisticamente significativas pelo Teste $\mathrm{F}$ ao nível de $1 \%$. Deve-se, portanto, relacionar esse resultado a heterogeneidade dos dados, especialmente no caso da microbacia $E$, e a respectiva amplitude de variação, conforme se verifica nas Figuras 34 e 35.

Tabela 11. ANOVA para a densidade do solo na microbacia E: linha de plantio e entre linhas

\begin{tabular}{ccccccc}
\hline Efeito & GL efeito & QM efeito & GL resíduo & QM resíduo & $F$ & $P$ \\
\hline Local & 1 & 0,137769 & 158 & 0,021700 & 6,348794 & 0,012739
\end{tabular}

Como se observa na Figura abaixo, foram encontrados maiores valores de densidade do solo entre linhas. Na linha de plantio, para os valores encontrados entre uma árvore e outra, a densidade do solo foi menor.

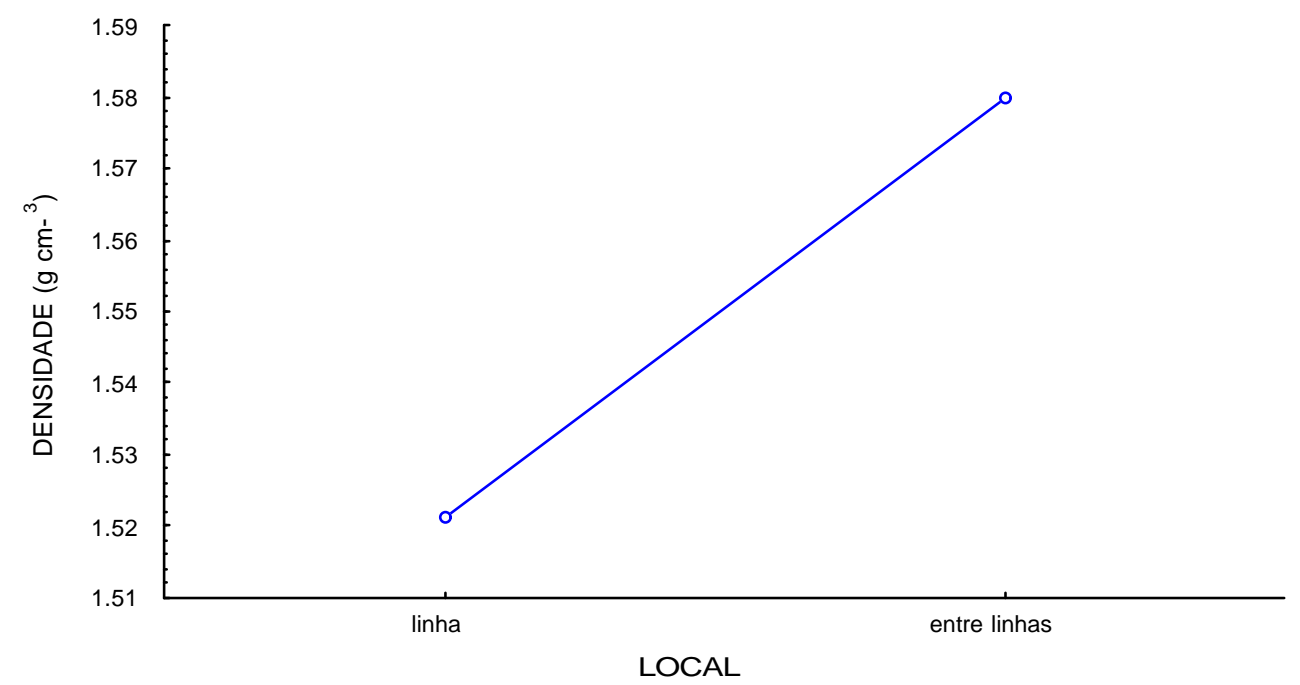

Figura 34 - Densidade do solo na microbacia E 
Estes resultados não implicam, necessariamente, em condições adversas ao ecossistema se considerada a amplitude de variação observada.

De um modo geral, os menores valores de densidade do solo na linha de plantio e os maiores valores entre linhas seguem o padrão observado em outros estudos, demonstrando o efeito residual das operações florestais. Comportamento semelhante é observado quando comparado aos dados de compactação do solo, sendo os valores mais elevados observados entre linhas e os menores, na linha.

Tabela 12. ANOVA: densidade do solo para a microbacia P: trilha e fora da trilha de pisoteio do gado

\begin{tabular}{lllllll}
\hline Efeito & GL efeito & QM efeito & GL residuo & QM residuo & $F$ & $\mathrm{P}$ \\
Local & 1 & 0,056836 & 158 & 0,001375 & 41,32518 & 0,000000 \\
\hline
\end{tabular}

Conforme observa-se na Figura 35, para a microbacia $P$, os valores mais elevados de densidade referem-se àtrilha de pisoteio do gado, enquanto que fora da trilha esses valores foram menores.

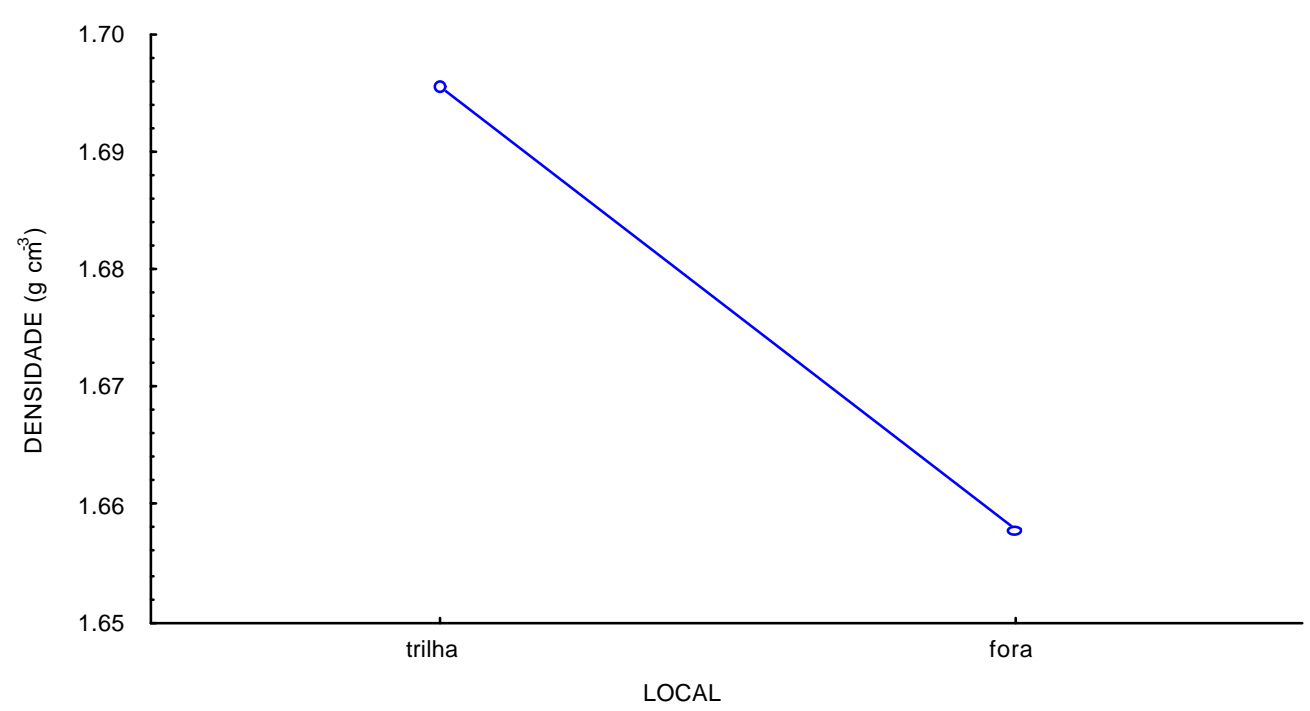

Figura 35 - Densidade do solo verificada na microbacia P

O resultado altamente significativo, no caso da microbacia $\mathrm{P}$, está relacionado a uma maior homogeneidade dos dados avaliados. 
Como a profundidade é uma variável dependente, limitou-se a explorar de modo mais minucioso a camada superior, comparando os efeitos entre os locais, dentro de cada microbacia. As diferenças de densidade e umidade do solo entre os ecossistemas foram analisadas individualmente e são apresentadas a seguir para as duas profundidades avaliadas (Tabela 13 e Tabela 14).

Tabela 13. Média e desvio padrão da densidade e umidade do solo na camada de 5 a $10 \mathrm{~cm}$ de profundidade

\begin{tabular}{llllll}
\hline Microbacia & \multicolumn{1}{c}{ Local } & Média & $\begin{array}{c}\rho\left(\mathrm{g} / \mathrm{cm}^{3}\right) \\
\text { Desv Pad }\end{array}$ & Média & $\begin{array}{c}\text { U\% } \\
\text { Desv Pad }\end{array}$ \\
\cline { 3 - 5 } & Linha de plantio & 1,50 & 0,14 & 5,13 & 2,06 \\
\multirow{3}{*}{ Pasto } & Fora da linha & 1,54 & 0,15 & 4,77 & 1,17 \\
& Trilho do gado & 1,70 & 0,04 & 3,93 & 0,62 \\
& Fora do trilho & 1,65 & 0,03 & 3,62 & 0,52 \\
\hline
\end{tabular}

Quando comparados os valores de densidade para a profundidade de 5 a $10 \mathrm{~cm}$ na linha e fora da linha de plantio para a microbacia E, os resultados não foram estatisticamente significativos, o que se deve a heterogeneidade do plantio florestal já mencionada e da própria composição da estrutura e distribuição de suas raízes. Há que se mencionar, também, os diferentes tratos culturais aplicados na linha de plantio, a exemplo do sulcamento e, entre linhas, como a atividade de máquinas florestais, que também alteram a densidade e os níveis de compactação do solo.

Já os valores de densidade do solo para a profundidade de 5 a $10 \mathrm{~cm}$ na microbacia $P$, na trilha de pisoteio do gado e fora da trilha, foram estatisticamente significativos ao nível de $1 \%$ (Tabela 14). Contribuiu para esse resultado a homogeneidade dos dados, a baixa variância e o elevado número de amostras. A amplitude de variação dos dados observada na Figura 36 evidencia o exposto.

Tabela 14. ANOVA para os valores de densidade do solo da microbacia $P$ avaliados na trilha e fora da trilha, na profundidade de 5 a $10 \mathrm{~cm}$

\begin{tabular}{ccccccc}
\hline Efeito & GL efeito & QM efeito & GL resíduo & QM residuo & $F$ & $\mathrm{P}$ \\
\hline Prof. & 1 & 0,060245 & 78 & 0,001444 & 41,72855 & 0,000000 \\
\hline
\end{tabular}


Ao avaliar os valores de densidade do solo na profundidade de 5 a $10 \mathrm{~cm}$, a Figura 36 permite visualizar valores mais elevados na trilha do gado e valores menores fora da trilha seguindo, também, o comportamento apresentado nos resultados anteriores sem a distinção das profundidades, para o mesmo ecossistema.

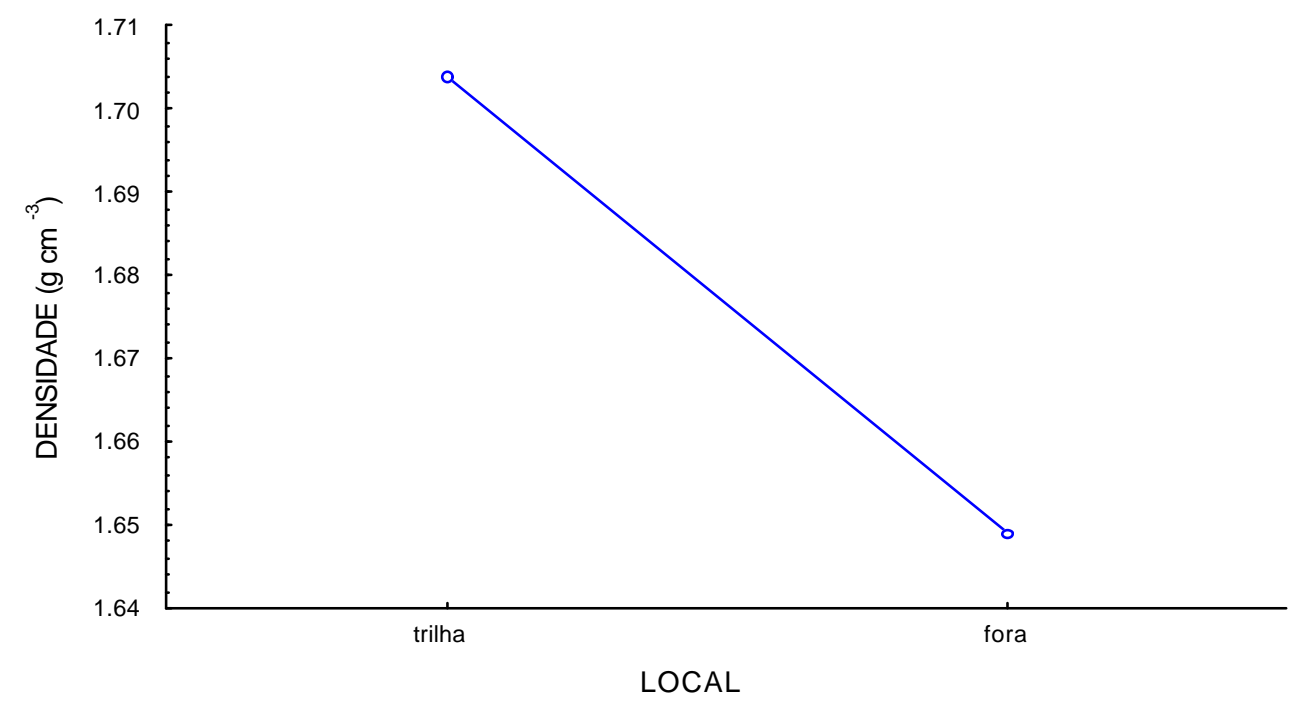

Figura 36 - Densidade do solo na microbacia P: valores observados na trilha e fora da trilha de pisoteio do gado, na profundidade de 5 a $10 \mathrm{~cm}$

Embora a amplitude de variação dos resultados de densidade do solo avaliados seja pequena $\left( \pm 0,05 \mathrm{~g} / \mathrm{cm}^{3}\right)$, o resultado é pertinente àqueles observados na literatura, ou seja, em ambientes com uma intensidade de movimentação maior, no caso da trilha, pela concentração do pisoteio do gado, os valores de densidade do solo tendem a ser mais elevados logo, os de compactação .

Ao avaliarem os efeitos da sobreposição das passadas dos pneus dos tratores florestais no nível de compactação do solo, em quatro faixas de profundidade, num povoamento de eucalipto híbrido, usando um sistema mecanizado de colheita da madeira, Lima et al. (2000) detectaram uma maior intensidade dos efeitos no nível de profundidade de 0 a $10 \mathrm{~cm}$, para os parâmetros: densidade do solo, densidade de partículas, porosidade total, teor de água do solo e resistência do solo àpenetração.

Para a profundidade de 10 a $20 \mathrm{~cm}$ Lima et al. (2000) também detectaram maior intensidade nos efeitos para todos os parâmetros físicos do solo. O estudo verificou ainda que os efeitos do tráfego dos tratores sobre o solo foram maiores nas primeiras 
passadas. O teor de água no solo não apresentou diferenças significativas entre as profundidades avaliadas.

Os valores de densidade e teor de umidade do solo na camada de 12,5 a 17,5 cm de profundidade expressam também uma maior variância dos dados observados na microbacia E, em função dos aspectos mencionados anteriormente, conforme se verifica pelas médias e desvios padrão apresentados na Tabela 15. Observa-se, também, uma maior homogeneidade dos dados na microbacia $P$.

Tabela 15. Média e desvio padrão da densidade e umidade do solo na camada de 12,5 a $17,5 \mathrm{~cm}$

\begin{tabular}{|c|c|c|c|c|c|}
\hline \multirow[t]{2}{*}{ Microbacia } & \multirow[t]{2}{*}{ Local } & \multicolumn{2}{|c|}{$\rho s\left(\mathrm{~g} / \mathrm{cm}^{3}\right)$} & \multicolumn{2}{|c|}{ U\% } \\
\hline & & Média & Desv Pad & Média & Desv Pad \\
\hline \multirow[t]{2}{*}{ Eucalipto } & Linha de plantio & 1,54 & 0,12 & 5,00 & 1,40 \\
\hline & Fora da linha & 1,59 & 0,15 & 4,86 & 0,70 \\
\hline \multirow[t]{2}{*}{ Pasto } & Trilho do gado & 1,69 & 0,03 & 4,39 & 0,55 \\
\hline & Fora do trilho & 1,67 & 0,03 & 3,93 & 0,03 \\
\hline
\end{tabular}

\subsection{Compactação}

De igual modo aos dados de densidade do solo, a análise dos dados de índice de cone considerou os efeitos da compactação do solo nos distintos locais dentro de cada ecossistema avaliado, admitindo a heterogeneidade e complexidade entre as microbacias.

Os resultados apresentaram diferenças significativas (1\%) entre os locais avaliados tanto na microbacia $E$ como para a microbacia $P$, conforme pode ser observado nas Tabelas 16 e 17.

Tabela 16. ANOVA para microbacia $\mathrm{E}$ : dados transformados para atingir homocedasticidade $(Y=\log X)$ e avaliar o efeito da compactação do solo na linha de plantio e entre linhas

\begin{tabular}{ccccccc}
\hline Efeito & GL efeito & QM efeito & GL resíduo & QM resíduo & $F$ & $p$ \\
\hline Local & 1 & 6,277640 & 1009 & 0,455379 & 13,78552 & 0,000216 \\
\hline
\end{tabular}


Na Figura 37 percebe-se que a microbacia E apresentou maiores índices de compactação do solo entre linhas e menores índices na linha.

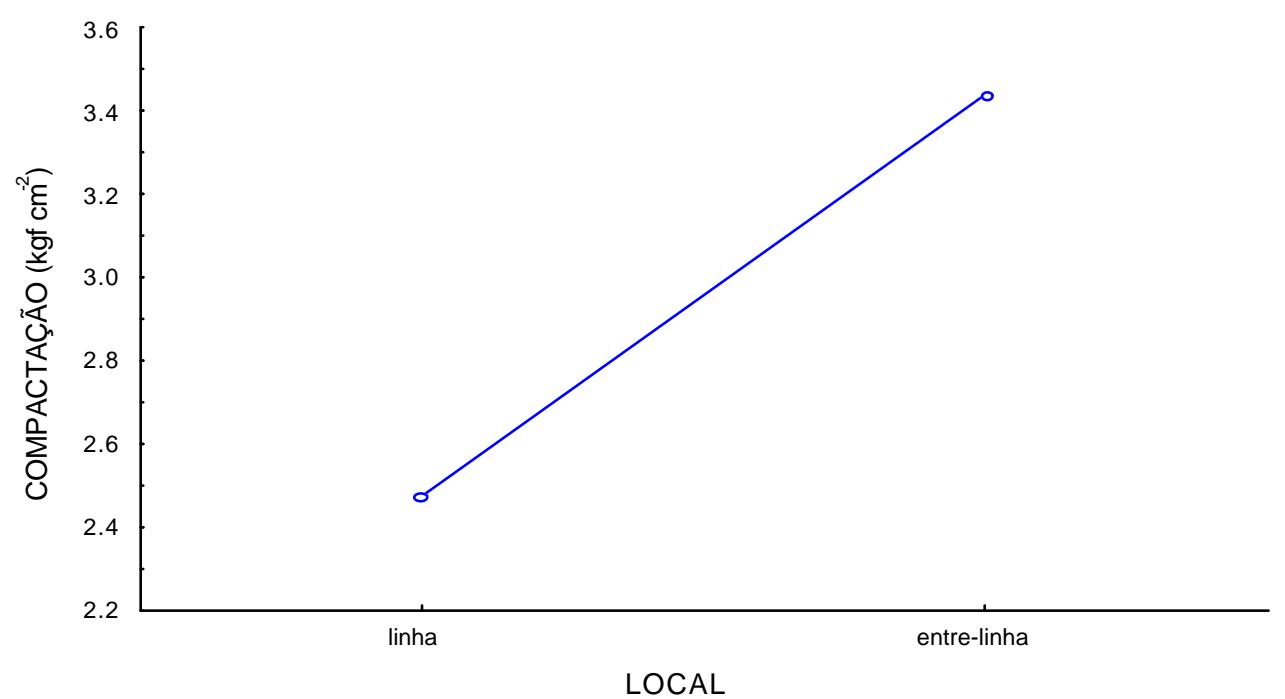

Figura 37 - Compactação do solo observada na microbacia E para a linha de plantio e entre linhas

Para a microbacia $P$, os resultados apresentaram diferenças significativas ao nível de $5 \%$ para os valores encontrados na trilha de pisoteio do gado e fora da trilha, sendo os índices mais elevados referentes ao primeiro caso e os mais baixos, referentes ao segundo (Figura 38).

Tabela 17. ANOVA para avaliar o efeito da compactação do solo na microbacia P: na trilha do gado e fora da trilha de pisoteio do gado

\begin{tabular}{ccccccc}
\hline \multicolumn{1}{c}{ Efeito } & GL efeito & QM efeito & GL residuo & QM residuo & $F$ & $P$ \\
\hline Local & 1 & 4,952847 & 502 & 1,113481 & 4,448076 & 0,035435 \\
\hline
\end{tabular}




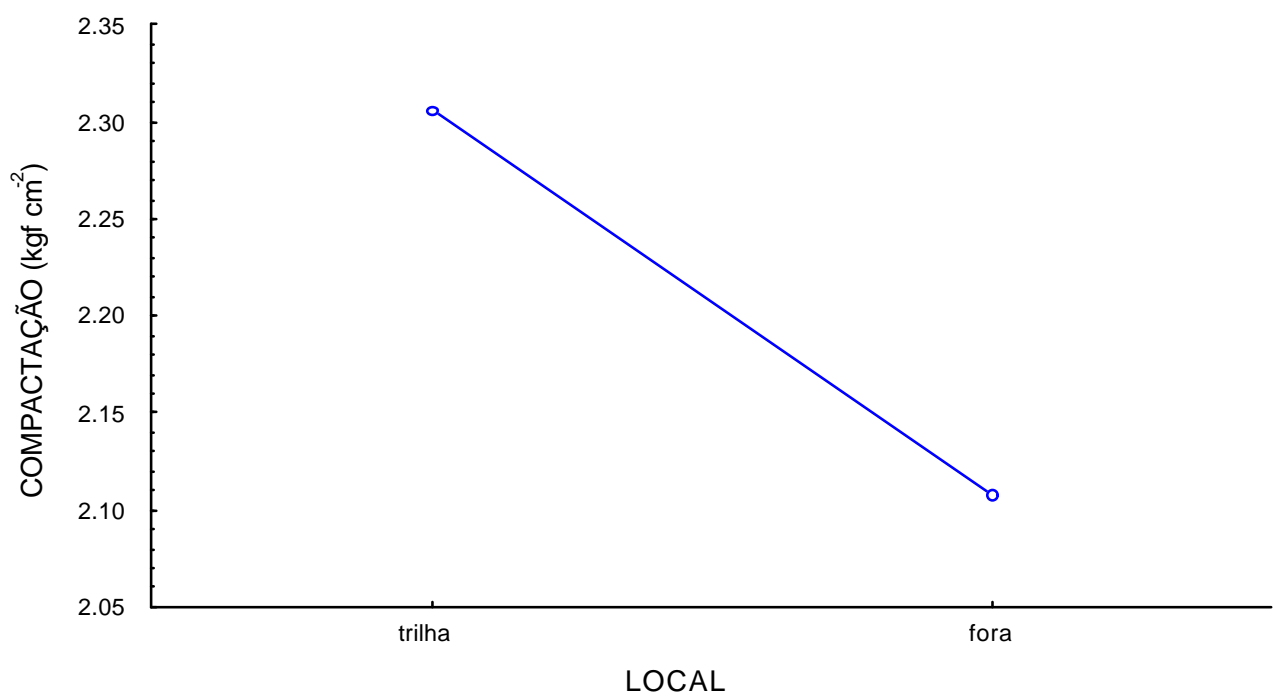

Figura 38 - Compactação do solo observada na microbacia P para a trilha de pisoteio do gado e fora da trilha

As Figuras 39 e 40, a seguir, ilustram a distribuição da compactação, expressa em kgf. $\mathrm{cm}^{-2}$, ao longo do perfil do solo, considerando a profundidade de 0 a $50 \mathrm{~cm}$ para os locais avaliados dentro de cada ecossistema.

A linha divisória no gráfico sinaliza o valor de índice de cone acima do qual a compactação do solo se torna um impedimento físico para o desenvolvimento das raízes (Seixas et al., 1998; Seixas, 2000).

$\mathrm{Na}$ microbacia $\mathrm{E}$ os valores encontrados entre linhas ultrapassaram os 25 a 30 kgf.cm ${ }^{-2}$ a partir dos $15 \mathrm{~cm}$, atingindo valores máximos aos $30 \mathrm{~cm}$ e decrescendo até os $50 \mathrm{~cm}$ de profundidade.

$\mathrm{Na}$ linha de plantio os índices observados acentuam a partir dos $30 \mathrm{~cm}$ de profundidade. 


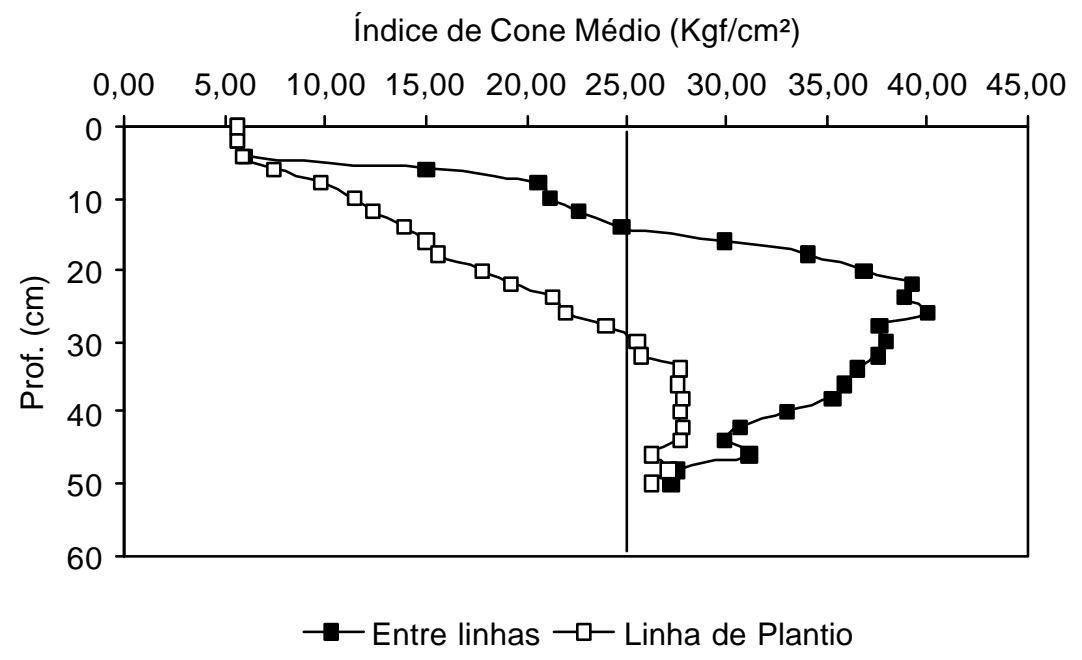

Figura 39 - Índices de cone para a microbacia E: valores encontrados na linha de plantio e entre linhas

A compactação do solo na microbacia $P$, expressa conforme os valores encontrados para a trilha de pisoteio do gado e àqueles fora da trilha permitem identificar um índice de compactação mais elevado na trilha de pisoteio do gado, na camada entre 5 a $30 \mathrm{~cm}$ de profundidade (Figura 40 e Apêndice 3).

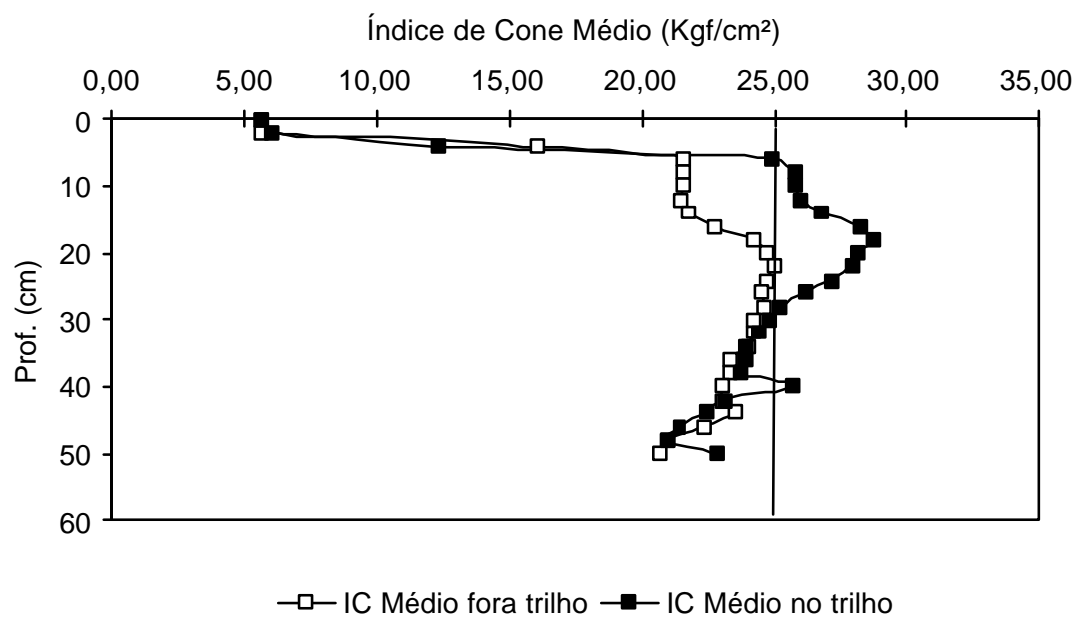

Figura 40 - Índices de cone para a microbacia P: valores observados na trilha e fora da trilha de pisoteio do gado 
$\mathrm{Na}$ microbacia $\mathrm{P}$, os índices de cone médios acima dos $25 \mathrm{kgf.cm}{ }^{-2}$ se concentraram na profundidade de 5 a $30 \mathrm{~cm}$ referente as trilhas de pisoteio do gado. Fora do trilho, os valores não expressam um impedimento físico ao desenvolvimento das plantas.

Seixas et al. (1998) verificaram valores de índice de cone que ultrapassaram a faixa de 25 e $30 \mathrm{kgf} / \mathrm{cm}^{2}$ na profundidade de solo entre 12 e $30 \mathrm{~cm}$, em uma floresta de Eucalyptus grandis.

\subsection{Indicadores qualitativos ou visuais da saúde das microbacias}

Algumas constatações feitas em campo, por estarem tão explicitadas visualmente na paisagem das microbacias, não exigiram a aplicação de metodologias de amostragem para constatar a ocorrência ou não do impacto e foram classificados como "indicadores visuais ou qualitativos da saúde da microbacia" (Figura 41).

Os indicadores visuais expressam, dessa forma, o resultado das ações humanas ao longo do tempo facilmente percebidas na paisagem.

Como os parâmetros de qualidade da água, os atributos visualmente percebidos na paisagem permitem integrar respostas às práticas de manejo na escala da microbacia. Para tal, afim de estabelecer uma avaliação mais consistente desses indicadores, procurou-se relacionar o estágio em que se encontram os impactos visuais com as medições efetuadas na escala micro e os respectivos indicadores de ordem quantitativa.

Os indicadores visuais observados na microbacia com pastagem são apresentados na Figura 41. Para a microbacia com eucalipto, esses indicadores foram percebidos em menor número de ocorrências e variedade, estando mais relacionados com o traçado de estradas e carreadores, o que não demostra uma ausência de perturbação nesse ecossistema daí, então, a necessidade de uma avaliação holística, considerando-se as escalas macro, meso e micro. Há que se considerar também as especificidades intrínsecas a cada lugar, a cada ecossistema. 


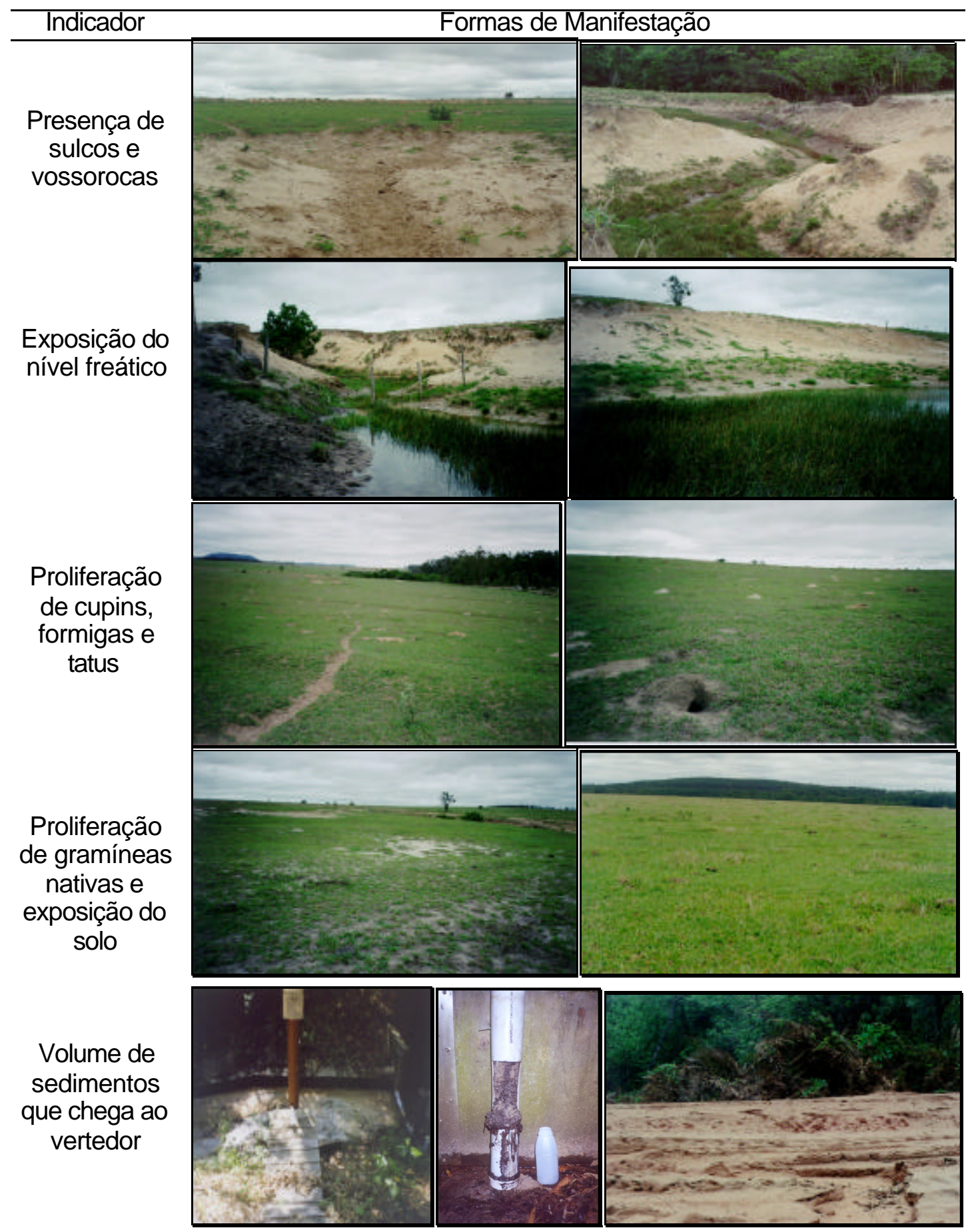

Figura 41 - Indicadores visuais propostos para integrar a avaliação do estado da saúde das microbacias monitoradas 
Resultados de pesquisas desenvolvidas pela Embrapa (1996) verificaram que os "cupins de montículo comumente infestam as pastagens em diversas regiões do Brasil e que os tatus são os mais eficientes em atuarem sobre os cupinzeiros escavando-os".

"Em pastagem degradada o capim permanece baixo, mesmo quando vedado, e a pastagem apresenta manchas de solo descoberto, geralmente compactado, infestação de plantas invasoras e de pragas (cupim, formiga) e erosão. Quando atinge esse estágio a pastagem não tem mais capacidade de recuperação natural" (Corrêa et al,1998).

Para o caso da pastagem, a proliferação de cupins, formigas e tatus indica, então, uma simplificação da diversidade biológica e um desequilíbrio do ecossistema decorrente de alterações na cadeia alimentar entre presa $\mathrm{x}$ predador.

As formigas, por sua vez, têm sido muito utilizadas em diferentes estudos como insetos indicadores de perturbação e para fins de manejo conservacionista. Resultados de pesquisa realizada em Feira de Santana (BA), sobre a influência da estrutura do habitat em comunidades de formigas, indicaram que a pobreza de espécies de formigas observadas na área degradada está ligada àdiminuição no número de nichos realizáveis desse ambiente (Santana-Reis \& Santos, 2001).

Odum (1985) ao discutir a relação entre estabilidade do sistema e a diversidade de espécies, afirma que "em ambientes homogêneos, a dominância tende a ser alta e a diversidade tende a diminuir".

Resultados semelhantes foram encontrados por Cintra et al. (2002) ao analisarem a riqueza de espécies de formigas em floresta primária, floresta secundária não queimada, floresta secundária queimada e pastagem. Os autores verificaram uma menor diversidade de espécies de formigas na pastagem. 


\section{CONCLUSÕES}

De um modo geral, verificou-se que os elementos utilizados para a caracterização hidrológicas das microbacias monitoradas estão interrelacionados, oferecendo, assim, respostas consistentes quanto as operações de manejo e mudanças naturais no ecossistema, quando avaliados em conjunto, para diferentes escalas.

A análise dos resultados apresentados nos hidrogramas e dos balanços hídricos das microbacias, considerando a limitação de dois anos de dados, permitiu identificar um padrão mais regularizado da vazão na microbacia $\mathrm{E}$, o que pode ser atribuído æ̀ condições de cobertura vegetal contribuindo para propiciar uma maior infiltração da água no solo, para o que também contribui o nível de compactação do solo.

A verificação do nível de compactação do solo indicou, para a microbacia $\mathrm{E}$, uma maior compactação nas entrelinhas do que na linha de plantio das árvores, em decorrência do efeito residual das operações florestais. Para a microbacia $\mathrm{P}$, a compactação do solo, expressa através dos valores de densidade do solo e índice de compactação, foi maior na trilha de pisoteio do gado do que fora da trilha.

As análises de qualidade da água do deflúvio das microbacias indicam uma maior variação nas concentrações, para os parâmetros físico-químicos, avaliadas na microbacia $\mathrm{P}$, associadas à ocorrência de precipitação, mostrando uma participação efetiva do escoamento direto nas perdas e fluxos de nutrientes. Os indicadores visuais, num primeiro momento, indicavam essa tendência através, por exemplo, da presença de vossorocas e mau estado de cobertura do solo. 
Os indicadores visuais se mostraram condizentes com as respostas hidrológicas observadas nas microbacias, o que lhes confere importante papel, em termos de praticidade operacional, no monitoramento ambiental de microbacias hidrográficas.

Algumas dificuldades observadas no decorrer do trabalho são, a seguir, apontadas no sentido de sugerir aperfeiçoamentos no monitoramento ambiental, de modo a permitir uma melhor qualidade dos dados coletados.

Uma das dificuldades deveu-se a problemas com os linígrafos, ocasionando a perda de dados. Um outro caso refere-se ao período de armazenamento das amostras para análises de qualidade da água.

Sugere-se a criação de um arquivo ou caderno de campo para anotar as atividades de intervenção efetuadas nas microbacias a fim de relacioná-las æ̀̀ respectivas respostas hidrológicas e, futuramente, orientar melhores práticas de manejo.

Sugere-se a inclusão da análise de sedimentos voláteis e não-voláteis na água do deflúvio, a fim de identificar sua origem.

Há que se ressaltar que, no período da pesquisa, procurou-se contactar o proprietário da fazenda a fim de levá-lo à microbacia com pastagem e mostrar os impactos decorrentes do manejo inadequado, para o que não se obteve êxito. 


\section{REFERÊNCIAS BIBLIOGRÁFICAS}

ALBUQUERQUE, G.B.; RODRIGUES, R.R. A vegetação do Morro de Araçoiaba, Floresta Nacional de Ipanema, Iperó (SP). Scientia Forestalis, n.58, p.145-159, 2000.

AMORIM NETO, M.S. Balanço hídrico segundo Thorntwaite \& Mather (1955).

Petrolina: EMBRAPA, Centro de Pesquisa Agropecuária do Trópico Semi-Árido, 1989. (Comunicado Técnico, 34).

ARCOVA, F.C.S. Balanço hídrico, características do deflúvio e calibragem de duas microbacias hidrográficas na Serra do Mar. Piracicaba, 1996. 130 p. Dissertação (Mestrado) - Escola Superior de Agricultura "Luiz de Queiroz", Universidade de São Paulo.

ARCOVA, F.C.S.; CICCO, V. de. Qualidade da água de microbacias com diferentes usos do solo na região de Cunha, Estado de São Paulo. Scientia Forestalis, n.56, p.125-134, dez. 1999.

AZEVEDO, E.C. Vazão e características físicas e químicas do deflúvio de microbacias hidrográficas cobertas com mata nativa, pastagem e Eucalyptus grandis. Viçosa, 1995. 92p. Dissertação (Mestrado) - Universidade Federal de Viçosa.

AZEVEDO, E.C. de; COSTA, L.M. da; FONTES, L.E.F.; PETERNELLI, L.A. Características físicas e químicas do deflúvio de microbacias hidrográficas cobertas com mata nativa, pastagem e Eucalyptus grandis. Revista Árvore, v.19, n.4, p.559$571,1995$. 
ANDRADE, G.C. Efeitos do reflorestamento e do desmatamento sobre a hidrologia, erosão de solo e fluxo de nutrientes em microbacias no semi-árido do Rio Grande do Norte. Piracicaba, 1991. 108 p. Dissertação (Mestrado) - Escola Superior de Agricultura "Luiz de Queiroz", Universidade de São Paulo.

BOMFIM, E.R.P. Tratamento físico associado à adubação na recuperação de pastagem degradada de braquiária. Lavras, 2001. 100p. Dissertação (Mestrado) Universidade Federal de Lavras.

BRADY, N.C. Natureza e propriedade dos solos. 7. ed. Trad. de A.B.N.FIGUEIREDO. Rio de Janeiro: Freitas Bastos, 1989. 898p.

CÂMARA, C.D. Efeitos do corte raso do eucalipto sobre o balanço hídrico e a ciclagem de nutrientes em uma microbacia experimental. Piracicaba, 1999. 75 p. Dissertação (Mestrado) - Escola Superior de Agricultura "Luiz de Queiroz", Universidade de São Paulo.

CÂMARA, C.D.; LIMA, W. de P. Corte raso de uma plantação de Eucalyptus saligna de 50 anos: impactos sobre o balanço hídrico e a qualidade da água em uma microbacia experimental. Scientia Forestalis, n.56, p.41-58, dez.1999.

CANDIDO, A. Os Parceiros do Rio Bonito: estudo sobre o caipira paulista e a transformação dos seus meios de vida. 7. ed. São Paulo: Duas Cidades, 1987. $284 p$.

CICCO, V.; FARIA, A.J.; ARCOVA, F.C.S.; SHIMOMICHI, P.Y. Determinação do balanço hídrico com emprego de bacia hidrográfica experimental em mata natural secundária. Boletim Técnico do Instituto Florestal de São Paulo, v.41, n.1, p.5567, 1987.

CINTRA, R. (Coord.). Dinâmica biológica de fragmentos florestais. Disponível na Web experimental com informações sobre o 13․ Relatório Anual sobre o projeto bi-nacional entre o Museu de História Natural dos EUA e o INPA - Inst. Nac. Pesquisas da Amazônia (1/Nov/1991 a 31/Out/1992). Projeto Dinâmica Biológica de Fragmentos Florestais, BDFF. http://www.bdt.org.br/bdff/ (10 fev. 03). 
CORBETT, E.S.; LYNCH, J.A. Management of streamside zones on municipal watersheds. In: TUCSON, A.Z; BROOMALL, P.A. (Org.). Riparian ecosystems and their management: reconciling conflicting uses. Northeastern Forest Experiment Station: Forest Service, 1985. p.187-190 (General Technical Report, 120).

CORRÊA, A.S.; KICHEL, A.N.; GROFF, B.; VALLE, C.B. do; FERNANDES, C.D.; CARDOSO, E.G.; SOUZA, F.H.D. de.; VIEIRA, J.M. (mai/1996, n.18). Quais as principais causas da degradação das pastagens e como se reconhece uma pastagem degradada ou em processo de degradação? Embrapa Gado de Corte. http://www.cnpgc.embrapa.br/tecnologias/quersabermais/500p/P279.html (05 fev. 2002).

COSSALTER, C.; PYE-SMITH, C. Fast-wood forestry. myths and realities. Jakarta: Forest Perspectives, CIFOR, 2003. 50 p.

COURCHESNE, F.; ROY, A.G.; BIRON, P.M.; COTE, B.; FYLES, J.; HENDERSHOT, W.H. Fluctuations of climatic conditions, elemental cycling and forest growth at the watershed scale. Environmental Monitoring and Assessment, v.67, p.161-177, 2001.

DÁRIO, F.R.; ALMEIDA, A.F. Influência de corredor florestal sobre a avifauna da Mata Atlântica. Scientia Forestalis, n.58. p99-109, dez. 2000.

DILLAHA, T.A.; RENEAU, R.B.; MOSTAGHIMI, S.; LEE, D. Vegetative filter strips for agricultural nonpoint source pollution control. Transactions of the American Society of Agricultural Engineers, v. 32, n.2, p.513-519, 1989.

EMPRESA BRASILEIRA DE PESQUISA AGROPECUÁRIA. Manual de métodos de análise de solo. 2. ed. Rio de Janeiro, 1997. 212p.

FERRAZ, F.F.B. Programa de monitoramento e modelagem de bacias hidrográficas - Promab e rede de monitoramento ambiental em microbacias Remam. Piracicaba: IPEF, 2002. 23 p. (Relatório de Avaliação. Período: 20012002) 
FULTON, S.; WEST, B. Forestry impacts on water quality. In: WEAR, D.N.; GREIS, J.G. (Ed.). Southern forest resource assessment. Asheville: USDA, Forest Service, Southern Research Station, 2002. cap.21, p.501-518. (General Technical Report, SRS-53).

GUNDERSON, L.H. Ecological resilience - in theory and application. Annual Review of Ecology and Systematics, v.31, p.425-439, 2000.

HAMILTON, L.S.; KING, P.N. Tropical forested watersheds: hydrologic and soils response to major uses or conversions. Dehra Dun: Westview Press, 1983. 155p.

HE, C.; MALCOLM, S.B.; DAHLBERG, K.A; FU, B. A conceptual framework for integrating hydrological and biological indicators into watershed management. Landscape and Urban Planning, v.49. p. 25-34, 2000.

HEM, J.D. (Ed). Study and interpretation of the chemical characteristics of natural water. 2. ed. Washington: Geological Survey Water-Supply, 1970. 363p.

INSTITUTO DE PESQUISAS TECNOLÓGICAS DO ESTADO DE SÃO PAULO. Mapa geológico do Estado de São Paulo. São Paulo, 1981, v.1, 126 p.

LEITÃO FILHO, H.F. Aspectos taxonômicos das florestas do Estado de São Paulo. In: CONGRESSO NACIONAL DE ESSÊNCIAS NATIVAS, São Paulo, 1982. Anais. São Paulo: Silvicultura em São Paulo, 1982. p.197-206.

LIMA, J.S.S.; SOUZA, A.P.; MACHADO, C.C.; VIEIRA, L.B.; FERNANDES, H.C. Avaliação da compactação do solo em um sistema de colheita da madeira. Revista Árvore, v.24, n.3, p.276-282, 2000.

LIMA, W.P. Impacto ambiental do eucalipto. 2.ed. São Paulo: EDUSP, 1996. 301p.

LIMA, W.P. Impacto ambiental del eucalipto en programas de forestacion: estudios realizados y resultados obtenidos en el monitoreo de los efectos ambientales de la forestación em Brasil. Uruguay Forestal, v.7, n.14, p. 5-12, 1997. 
LIMA, W.P.; ZAKIA, M.J.B. Indicadores hidrológicos em áreas Florestais. Série Técnica IPEF, v. 12, n. 31, p.53-64, 1998.

LIMA, W.P.; ZAKIA, M.J.B. Hidrologia de matas ciliares. In: RODRIGUES, R.R.; LEITÃO FILHO, A.F. (Org.). Matas ciliares: conservação e recuperação. São Paulo: EDUSP, 2000. cap.3, p.33-44.

LIMA, W.P.; ZAKIA, M.J.B.; CÂMARA, C. Implicações da colheita florestal e do preparo do solo na erosão e assoreamento de bacias hidrográficas. In: GONÇALVES, J.L.M.; STAPE, J.L. (Ed.) Conservação e cultivo de solos para plantações florestais. Piracicaba: IPEF, 2002. cap 11, p.373-391.

MEYBECK, M.; HELMER. R. An introduction to water quality. In: CHAPMAN, D. (Ed.) Water quality assessments: a guide to the use of biota, sediments and water in environmental monitoring. London: Chapman and Hall, 1992. cap.1, p.1-17.

MOLDAN, B.; CERNY, J (Ed.). Biogeochemistry of small catchments: a tool of environmental research. Prague: SCOPE, 1994. 405 p.

NASCIMENTO JÚNIOR, D.; BRANCO, R.H. Degradação de pastagens: diminuição da produtividade com o tempo; Conceito de sustentabilidade. 2001. http://www.forragicultura.com.br (25 mar. 2002).

PESSOTTI, J.E.S. Levantamento semidetalhado dos solos da fazenda Santa Terezinha. Campinas: Pessoti Serviços Agrícolas e Florestais, 1998.58 p.

ODUM, E.P. Ecologia. Rio de Janeiro: Interamericana, 1985. 439 p.

OLIVEIRA JUNIOR, E.D. Compactação do solo devido ao tráfego de carretas florestais com dois tipos de pneus inflados a diferentes pressões. Piracicaba, 1998. 67p. Dissertação (Mestrado) - Escola Superior de Agricultura "Luiz de Queiroz", Universidade de São Paulo.

RAIJ, B. van, ANDRADE, J.C., CANTARELLA, H.; QUAGGIO, J.A. Análise química para avaliação da fertilidade de solos tropicais. Campinas: Instituto Agronômico, 2001. 285p. 
RAIJ, B. van; CANTARELlA, H.; QUAGGIO, J.A.; FURLANI, A.M.C. (Ed.). Recomendações de adubação e calagem para o estado de São Paulo. 2.ed. São Paulo: Instituto Agronômico \& Fundação Instituto Agronômico de Campinas, 1996. 285p. (IAC. Boletim Técnico, 100).

REDE DE MONITORAMENTO AMBIENTAL DE MICROBACIAS. Conceitos teóricos. http://www.ipef.br/promab/members/origemremam.htm (03 nov. 2002).

REIGNER, I.C. Calibrating a watershed by using climatic data. Fernow: USDA, Forest Service, 1964. 32 p.

REINHART, K.G. Calibration of five small forested watersheds. Transactions of the American Geophysical Union, v.38, n.5. p 933-936, 1958.

RIZZINI, C.T. Nota prévia sobre a divisão fitogeográfica (florístico-sociológica) do Brasil. Revista Brasileira de Geografia, v.25, p.3-64, 1963.

RODIER, J.A. Utilization of the results from representative and experimental basins with a view to the management of water resources. Hydrological Sciences Bulletin, v.21, n.4, p.531-544, 1976.

RODRÍGUEZ ANIDO, N.M. Caracterização Hidrológica de uma microbacia experimental visando identificar indicadores de monitoramento ambiental. Piracicaba, 2002. 68 p. Dissertação (Mestrado) - Escola Superior de Agricultura "Luiz de Queiroz", Universidade de São Paulo.

SANTANA-REIS, V.P.G.; SANTOS, G.M.M. Influência da estrutura do habitat em comunidades de formigas (Hymenoptera - Formicidae) em Feira de Santana, Bahia, Brasil. Sitientibus. Série Ciências Biológicas, v.1, n.1, p.66-70, 2001.

SCARDUA, F.P. Caracterização hidrológica de uma microbacia hidrográfica da estação experimental de ciências florestais de Itatinga. Piracicaba, 1994. 70 p. Dissertação (Mestrado) - Escola Superior de Agricultura "Luiz de Queiroz", Universidade de São Paulo. 
SENTELHAS, P.C.; PEREIRA, A.R.; MARIN, F.R.; ANGELOCCI, L.R.; ALFONSI,R.R.; CARAMORI,P.H.; SWART, S. Balanço hídricos climatológicos de $\mathbf{5 0 0}$ localidades brasileiras (1998). Núcleo de Monitoramento Agroclimático. http://ce.esalq.usp.br/bhbrasil/Saopaulo/ltatinga.xls (15 mar. 2002)

SEIXAS, F. Compactação do solo devido àcolheita de madeira. Piracicaba, 2000. 75p. Tese (Livre-Docência) - Escola Superior de Agricultura "Luiz de Queiroz", Universidade de São Paulo.

SEIXAS, F. Efeitos físicos da colheita mecanizada de madeira sobre o solo. In: GONÇALVES, J.L.M; STAPE, J.L. (Ed.). Conservação e cultivo de solos para plantações florestais. Piracicaba: IPEF, 2002. cap. 9, p.315-350.

SEIXAS, F.; OLIVEIRA JÚNIOR, E.D.; SOUZA, C.R de. Efeito da camada de resíduos florestais na compactação do solo causada pelo transporte primário da madeira. Scientia Forestalis, n. 54, p.9-16, dez. 1998.

SHUMACHER, M.V.; HOPPE, J.M. A floresta e a água. Porto Alegre: Pallottii, 1998. $70 \mathrm{p}$.

SILVA, A.P.; CARMEN IMHOFF, S. del.; TORMENA, C.A.; LEÃO, T.P. Avaliação da compactação de solos florestais. In: GONÇALVES, J.L.M; STAPE, J.L. (Ed.). Conservação e cultivo de solos para plantações florestais. Piracicaba: IPEF, 2002. Cap.9. p.351-372.

SILVA, L.F. da. Solos Tropicais: aspectos pedológicos, ecológicos e de manejo. São Paulo: Terra Brasilis, 1995. $137 \mathrm{p}$.

SILVEIRA, A.A. da. Fontes, chuvas e florestas. Belo Horizonte: Imprensa official do Estado de Minas Geraes, 1923. 344p.

STRAHLER, A.N. Quantitative analysis of watershed geomorphology. Transactions of the American Geophysical Union, v. 38, p.913-920, 1964. 
SWANK, W.T.;MEYER, J.L.; CROSSLEY JUNIOR, A. Long-term ecological research: Coweeta history and perspectives. In: BARRET, T.L. Holistic science: the evolution of the Georgia Institute of Ecology (1940-2000). Ann Arbor: Sheridan Book, 2001cap.8, p.143-163.

VILELLA, S.M.; MATTOS, A. Hidrologia aplicada. São Paulo: Mcgraw-Hill do Brasil, 1975. 245p.

VITAL, A.R.T. Efeitos do corte raso no balanço hídrico e na ciclagem de nutrientes em uma microbacia reflorestada com eucalipto. Piracicaba, 1996.106p. Dissertação (M.S.) - Escola Superior de Agricultura "Luiz de Queiroz", Universidade de São Paulo.

WALKER, J.; REUTER, D.J. Indicators of catchment health: a technical perspective. Collingwood Victoria: CSIRO, 1996. $174 \mathrm{p}$.

WHITEHEAD, P.G.; ROBINSON, M. Experimental basin studies: international and historical perspective of forest impacts. Journal of Hydrology, v.145, p.217-230, 1993.

WILSON, A.; LINDENMAYER, D. Wildlife corridors: their potential role in the conservation of biodiversity in rural Australia. Australian Journal of Soil and Water Conservation, v.9, p22-28, 1996.

ZAKIA, M.J.B. Identificação e caracterização da zona ripária em uma microbacia experimental: implicações no manejo de bacias hidrográficas e na recomposição de florestas. São Carlos, 1998. 98 p. Tese (Doutorado) - Escola de Engenharia de São Carlos, Universidade de São Paulo. 
APÊNDICES 
Apêndice 1.1. Série histórica de precipitação coletada na estação pluviométrica E5-064 instalada na Faz. Santa Terezinha.

\begin{tabular}{lcccccccccc} 
Meses & $\mathbf{1 9 8 0}$ & $\mathbf{1 9 8 1}$ & $\mathbf{1 9 8 2}$ & $\mathbf{1 9 8 3}$ & $\mathbf{1 9 8 4}$ & $\mathbf{1 9 8 5}$ & $\mathbf{1 9 8 6}$ & $\mathbf{1 9 8 7}$ & $\mathbf{1 9 8 8}$ & $\mathbf{1 9 8 9}$ \\
Jan & 100,50 & 235,90 & 256,10 & 335,00 & 162,40 & 191,10 & 206,10 & 258,70 & 176,20 & 334,70 \\
Fev & $\mathbf{2 3 4 , 7 0}$ & 80,30 & $\mathbf{2 3 0 , 5 1}$ & 174,40 & 50,30 & 168,90 & 182,30 & 185,10 & 154,70 & 232,80 \\
Mar & 111,70 & 153,30 & $\mathbf{8 8 , 1 0}$ & 184,70 & 43,10 & 284,50 & 225,20 & 127,50 & 156,70 & 108,90 \\
Abr & 82,80 & 25,30 & 66,10 & 60,80 & 87,90 & 123,60 & 44,20 & 40,70 & 123,00 & 60,10 \\
Mai & 8,60 & 23,40 & $\mathbf{5 4 , 8 3}$ & 257,80 & 81,50 & 70,30 & 70,80 & 283,10 & 144,20 & 48,80 \\
Jun & 42,40 & 84,00 & 259,50 & 340,10 & 0,20 & 9,40 & 0,10 & 171,90 & 37,70 & 57,80 \\
Jul & 0,20 & 25,20 & 62,70 & 26,60 & 0,80 & 10,40 & 15,10 & 24,00 & 0,10 & 96,30 \\
Ago & 34,60 & 16,60 & 10,30 & 0,80 & 158,40 & 14,10 & 146,20 & 11,90 & 0,00 & 37,30 \\
Set & 78,20 & 17,70 & 29,50 & 234,70 & 103,40 & 51,20 & 70,10 & 73,80 & 37,70 & 74,20 \\
Out & 69,70 & 198,90 & 222,20 & 135,20 & 27,30 & $\mathbf{3 5 , 7 1}$ & 94,30 & 75,00 & 165,50 & 77,10 \\
Nov & 170,20 & $\mathbf{1 4 6 , 0 6}$ & 227,30 & 122,50 & 157,20 & 133,90 & 183,60 & 177,80 & 113,20 & 92,80 \\
Dez & 250,80 & $\mathbf{2 1 1 , 8 7}$ & 231,30 & 204,80 & 113,80 & 158,60 & 294,30 & 218,30 & 103,50 & 98,20 \\
TOTAL & 1184,40 & 1218,53 & $1738,442077,40$ & 986,30 & 1251,71 & 1532,30 & 1647,80 & 1212,50 & 1319,00 \\
\hline
\end{tabular}

\begin{tabular}{ccccccccccc} 
Meses & 1990 & 1991 & $\mathbf{1 9 9 2}$ & $\mathbf{1 9 9 3}$ & $\mathbf{1 9 9 4}$ & $\mathbf{1 9 9 5}$ & $\mathbf{1 9 9 6}$ & $\mathbf{1 9 9 7}$ & $\mathbf{1 9 9 8}$ & $\mathbf{1 9 9 9}$ \\
\hline Jan & 332,30 & 357,30 & 130,30 & 231,70 & 191,60 & 149,70 & 128,70 & 456,50 & 149,10 & 252,20 \\
Fev & 106,00 & 282,90 & 159,60 & 307,20 & 141,70 & 318,40 & 170,00 & 173,50 & 375,00 & 233,40 \\
Mar & 291,30 & 405,40 & 264,80 & 190,70 & 79,80 & $\mathbf{6 0 , 2 5}$ & 254,90 & 53,20 & 253,20 & 150,30 \\
Abr & 77,90 & 153,40 & 97,90 & 42,60 & 84,90 & 74,70 & 70,40 & 22,40 & 169,70 & 65,30 \\
Mai & 87,60 & 44,20 & 41,90 & 157,20 & 49,70 & 96,70 & 47,50 & 83,00 & 127,40 & 33,90 \\
Jun & 23,20 & 68,90 & 7,80 & 66,60 & 33,80 & 60,00 & 54,60 & 114,70 & 19,10 & 98,80 \\
Jul & 140,20 & 24,70 & 42,30 & 14,30 & 13,30 & 50,20 & 11,30 & 92,70 & 17,80 & 33,30 \\
Ago & 47,10 & 15,40 & 28,20 & 59,60 & 0,20 & 96,70 & 19,00 & 65,40 & 43,30 & 0,00 \\
Set & 84,70 & 63,20 & 156,10 & 179,40 & 0,00 & 65,90 & 179,70 & 179,30 & 108,80 & 89,60 \\
Out & 107,10 & 121,70 & 141,00 & 120,70 & 75,00 & 161,20 & 80,60 & 171,40 & 163,00 & 47,80 \\
Nov & 134,40 & 109,60 & 137,80 & 98,90 & 116,60 & 111,30 & 73,60 & 238,10 & 22,10 & 39,10 \\
Dez & 149,90 & 224,70 & 117,60 & 138,60 & 215,00 & 73,70 & 179,82 & 273,70 & 201,10 & 49,40 \\
TOTAL & 1581,70 & 1871,40 & 1325,30 & 1607,50 & 1001,60 & 1318,75 & 1270,12 & 1923,90 & $1649,601093,10$ \\
\hline
\end{tabular}


Apêndice 1.2. Valores médios mensais de precipitação e vazão registrados no período de nov/00 a out/02.

\begin{tabular}{|c|c|c|c|c|c|}
\hline \multirow{2}{*}{ Data } & \multirow{2}{*}{$\mathrm{P}(\mathrm{mm})$} & \multicolumn{2}{|c|}{ Microbacia $\mathrm{C}$} & \multicolumn{2}{|c|}{ Microbacia $P$} \\
\cline { 3 - 6 } & & Cota & $\begin{array}{c}\text { Vazão } \\
\left(\mathrm{m}^{3} / \mathrm{s}\right)\end{array}$ & Cota & $\begin{array}{c}\text { Vazão } \\
\left(\mathrm{m}^{3} / \mathrm{s}\right)\end{array}$ \\
\hline Nov-00 & 19,23 & 0,051 & 0,0035 & 0,063 & 0,0058 \\
Dez-00 & 26,54 & 0,053 & 0,0040 & 0,065 & 0,0060 \\
Jan-01 & 21,47 & 0,048 & 0,0031 & 0,068 & 0,0076 \\
Fev-01 & 17,12 & 0,048 & 0,0029 & 0,088 & 0,0129 \\
Mar-01 & 18,88 & 0,045 & 0,0024 & 0,085 & 0,0118 \\
Abr-01 & 7,20 & 0,040 & 0,0017 & 0,067 & 0,0061 \\
Mai-01 & 9,11 & 0,044 & 0,0020 & 0,069 & 0,0067 \\
Jun-01 & 10,13 & 0,043 & 0,0020 & 0,067 & 0,0061 \\
jul-01 & 7,90 & 0,042 & 0,0017 & 0,065 & 0,0057 \\
ago-01 & 7,78 & 0,041 & 0,0017 & 0,064 & 0,0054 \\
set-01 & 6,23 & 0,040 & 0,0016 & 0,063 & 0,0052 \\
out-01 & 18,52 & 0,044 & 0,0025 & 0,069 & 0,0106 \\
nov-01 & 15,34 & 0,041 & 0,0020 & 0,066 & 0,0063 \\
dez-01 & 13,81 & 0,044 & 0,0023 & 0,091 & 0,0144 \\
jan-01 & 12,01 & 0,045 & 0,0026 & 0,074 & 0,0095 \\
fev-01 & 12,81 & 0,043 & 0,0020 & 0,076 & 0,0094 \\
mar-01 & 5,51 & 0,040 & 0,0017 & 0,068 & 0,0064 \\
abr-01 & 3,05 & 0,038 & 0,0014 & 0,064 & 0,0055 \\
mai-02 & 10,36 & 0,045 & 0,0024 & 0,069 & 0,0069 \\
jun-02 & 0,25 & 0,040 & 0,0016 & 0,064 & 0,0054 \\
jul-02 & 3,88 & 0,038 & 0,0013 & 0,064 & 0,0054 \\
ago-02 & 24,18 & 0,055 & 0,0058 & 0,064 & 0,0054 \\
set-02 & 15,41 & 0,037 & 0,0013 & 0,061 & 0,0048 \\
out02 & 24,26 & 0,033 & 0,0010 & 0,063 & 0,0054 \\
\hline
\end{tabular}

Apêndice 1.3. Componentes dos Hidrogramas: Escoamento direto ( $E d-m m) ; E$ base (Eb - $\mathrm{mm}) ; \mathrm{Q}(\mathrm{mm})$ calculados para as microbacias $\mathrm{E}$ e P.

\begin{tabular}{|c|c|c|c|c|c|c|c|c|}
\hline BACTA & TINICIOED. & $\begin{array}{c}\text { PICO } \\
\text { HIDROGRAMA }\end{array}$ & $\begin{array}{l}\text { TERIMINO } \\
\text { E D. }\end{array}$ & $\begin{array}{l}\text { ED. } \\
\text { (MIN) }\end{array}$ & $\begin{array}{c}\mathrm{P} \\
(\mathrm{MM})\end{array}$ & $\begin{array}{c}\mathrm{Q} \\
(\mathrm{MM})\end{array}$ & $\begin{array}{l}\text { ED. } \\
\text { (MM) }\end{array}$ & $\begin{array}{l}\text { EB. } \\
\text { (MM) }\end{array}$ \\
\hline $\mathrm{MP}$ & 11/10/01-19:15 & $1 / 10-20: 00$ & $11 / 10 / 01-20: 45$ & 95 & 89,2 & 6,07 & 1,48 & 4,59 \\
\hline ME & 11/10/01 - 20:25 & $11 / 10-20: 50$ & 11/10/01 - 22:10 & 110 & 89,2 & 2,69 & 1,4 & 1,29 \\
\hline MP & 28/11/01-23:05 & $28 / 11-23: 20$ & $29 / 11 / 01-10: 15$ & 675 & 41,2 & 14,26 & 0,71 & 13,55 \\
\hline ME & 28/11/01 - 23:15 & 29/11 - 0:15 & 29/11/01 - 10:15 & 665 & 41,2 & 4,64 & 0,52 & 4,12 \\
\hline $\mathrm{MP}$ & 07/04/02 - 17:20 & $07 / 04-17: 35$ & $07 / 04 / 02-21: 05$ & 480 & 10,2 & 2,21 & 0,4 & 1,81 \\
\hline ME & 07/04/02 - 18:25 & 07/04 - 19:00 & 08/04/02 - 1:25 & 465 & 10,2 & 0,74 & 0,27 & 0,47 \\
\hline $\mathrm{MIP}$ & 20/09/02 - 14:05 & $29 / 09-14: 55$ & 21/09/02-9:10 & 1550 & 26,2 & 136,9 & 8,3 & 128,6 \\
\hline ME & 20/09/02 - 14:25 & 29/09 - 20:40 & 21/09/02 - 8:45 & 1150 & 26,2 & 3,63 & 0,4 & 3,23 \\
\hline
\end{tabular}


Apêndice 2.1. Concentração média mensal dos parâmetros físicos no deflúvio da microbacia $\mathrm{E}$ e precipitação média mensal em $\mathrm{mm}$.

\begin{tabular}{ccccccc}
\hline Mës & P & lurbidez & Cor Real & Condutividade Sedimentos & pH \\
& $(\mathrm{mm})$ & FTU & PtCo & MScm $^{-1}$ & $(\mathrm{mg} / \mathrm{l})$ & \\
\hline Nov/01 & 15,34 & 41 & 23 & 0,05 & 83,6 & 5,8 \\
Dez/01 & 13,81 & 30 & 28 & 0,05 & 64,9 & 5,6 \\
jan/02 & 12,01 & 101 & 71 & 0,05 & 563,0 & 5,7 \\
fev/02 & 12,81 & 38 & 23 & 0,04 & 169,5 & 5,8 \\
Mar/02 & 5,51 & 20 & 21 & 0,06 & 73,5 & 5,6 \\
abr/02 & 3,05 & 17 & 25 & 0,05 & 21,0 & 5,8 \\
Mai/02 & 10,36 & 42 & 48 & 0,04 & 68,6 & 5,6 \\
jun/02 & 0,25 & 23 & 28 & 0,04 & 93,4 & 5,8 \\
jul/02 & 3,88 & 24 & 29 & 0,04 & 49,5 & 5,8 \\
Ago/02 & 24,18 & 60 & 27 & 0,04 & 169,5 & 5,8 \\
Set/02 & 15,41 & 52 & 17 & 0,07 & 57,3 & 6,0 \\
Out/02 & 24,26 & 58 & 17 & 0,05 & 213,7 & 5,5 \\
\hline
\end{tabular}

Apêndice 2.2. Concentração média mensal dos parâmetros físicos no deflúvio da microbacia $\mathrm{P}$ e precipitação média mensal.

\begin{tabular}{ccccccc}
\hline Mès & $\begin{array}{c}\mathrm{P} \\
(\mathrm{mm})\end{array}$ & $\begin{array}{c}\text { Turbidez } \\
\text { FTU }\end{array}$ & $\begin{array}{c}\text { Cor Real } \\
\text { PtCo }\end{array}$ & $\begin{array}{c}\text { Condutividade } \\
\mathrm{mScm}^{-1}\end{array}$ & $\begin{array}{c}\text { Sedimentos } \\
(\mathrm{mg} / \mathrm{l})\end{array}$ & $\mathrm{pH}$ \\
\hline Nov/01 & 15,34 & 282 & 73 & 0,06 & 15307,9 & 6,1 \\
Dez/01 & 13,81 & 351 & 30 & 0,06 & 7078,1 & 6,0 \\
jan/02 & 12,01 & 450 & 56 & 0,06 & 7952,5 & 5,8 \\
fev/02 & 12,81 & 450 & 25 & 0,05 & 1570,5 & 5,5 \\
mar/02 & 5,51 & 329 & 4 & 0,06 & 1759,2 & 6,0 \\
abr/02 & 3,05 & 143 & 19 & 0,06 & 367,7 & 6,2 \\
mai/02 & 10,36 & 450 & 30 & 0,05 & 4184,3 & 5,9 \\
jun/02 & 0,25 & 183 & 22 & 0,05 & 673,0 & 6,1 \\
jul/02 & 3,88 & 225 & 17 & 0,05 & 612,0 & 6,0 \\
ago/02 & 24,18 & $>450$ & 55 & 0,05 & 3510,5 & 5,8 \\
set/02 & 15,41 & $>450$ & 11 & 0,06 & 1330,8 & 6,0 \\
out/02 & 24,26 & $>450$ & 25 & 0,13 & 6924,9 & 5,8 \\
\hline
\end{tabular}


Apêndice 3. Dados de Índice de cone do solo e efeitos avaliados em cada microbacia e respectivos.

\begin{tabular}{|c|c|c|c|c|c|}
\hline \multicolumn{3}{|c|}{ Microbacia E } & \multicolumn{3}{|c|}{ Microbacia P } \\
\hline $\begin{array}{c}\text { IC Médio } \\
\text { (linha plantio) }\end{array}$ & $\begin{array}{l}\text { IC Médio } \\
\text { (entrelinha) }\end{array}$ & $\begin{array}{l}\text { Prof. } \\
\text { (cm) }\end{array}$ & $\begin{array}{c}\text { IC Médio } \\
\text { (trilho do gado) }\end{array}$ & $\begin{array}{l}\text { IC Médio } \\
\text { (fora trilho) }\end{array}$ & $\begin{array}{l}\text { Prof. } \\
(\mathrm{cm})\end{array}$ \\
\hline 5,60 & 5,60 & 0 & 5,60 & 5,60 & 0 \\
\hline 5,60 & 5,60 & 2 & 5,93 & 5,60 & 2 \\
\hline 5,79 & 5,89 & 4 & 12,31 & 16,06 & 4 \\
\hline 7,44 & 14,96 & 6 & 24,87 & 21,56 & 6 \\
\hline 9,79 & 20,57 & 8 & 25,84 & 21,56 & 8 \\
\hline 11,45 & 21,18 & 10 & 25,84 & 21,56 & 10 \\
\hline 12,30 & 22,57 & 12 & 26,06 & 21,49 & 12 \\
\hline 13,87 & 24,78 & 14 & 26,83 & 21,71 & 14 \\
\hline 14,97 & 29,93 & 16 & 28,26 & 22,78 & 16 \\
\hline 15,54 & 34,00 & 18 & 28,70 & 24,23 & 18 \\
\hline 17,76 & 36,86 & 20 & 28,14 & 24,74 & 20 \\
\hline 19,31 & 39,21 & 22 & 27,97 & 25,07 & 22 \\
\hline 21,29 & 38,84 & 24 & 27,13 & 24,70 & 24 \\
\hline 21,98 & 39,97 & 26 & 26,21 & 24,50 & 26 \\
\hline 24,00 & 37,65 & 28 & 25,17 & 24,63 & 28 \\
\hline 25,51 & 37,96 & 30 & 24,83 & 24,25 & 30 \\
\hline 25,70 & 37,49 & 32 & 24,41 & 24,27 & 32 \\
\hline 27,63 & 36,44 & 34 & 23,92 & 24,04 & 34 \\
\hline 27,59 & 35,83 & 36 & 23,96 & 23,28 & 36 \\
\hline 27,75 & 35,28 & 38 & 23,69 & 23,39 & 38 \\
\hline 27,63 & 33,06 & 40 & 25,71 & 23,10 & 40 \\
\hline 27,77 & 30,72 & 42 & 23,12 & 23,04 & 42 \\
\hline 27,59 & 29,94 & 44 & 22,42 & 23,52 & 44 \\
\hline 26,14 & 31,08 & 46 & 21,41 & 22,40 & 46 \\
\hline 27,09 & 27,57 & 48 & 20,93 & 20,98 & 48 \\
\hline 26,24 & 27,23 & 50 & 22,86 & 20,75 & 50 \\
\hline
\end{tabular}

